\title{
Evaluating changes in marine communities that provide ecosystem services through comparative assessments of community indicators
}

\author{
Kleisner Kristin M. ${ }^{1,2, *}$, Coll Marta ${ }^{3}$, Lynam Christopher P. ${ }^{4}$, Bundy Alida ${ }^{5}$, Shannon Lynne ${ }^{6}$, \\ Shin Yunne-Jai ${ }^{3,6}$, Boldt Jennifer L. ${ }^{7}$, Borges Maria F. ${ }^{8}$, Diallo Ibrahima ${ }^{9}$, Fox Clive ${ }^{10}$, \\ Gascuel Didier ${ }^{11}$, Heymans Johanna J. ${ }^{12}$, Juan Jorda Maria J. ${ }^{13,14}$, Jouffre Didier ${ }^{15}$, Large Scott I. ${ }^{2}$, \\ Marshall Kristin N. ${ }^{16}$, Ojaveer Henn ${ }^{17}$, Piroddi Chiara ${ }^{18}$, Tam Jorge ${ }^{19}$, Torres Maria A. ${ }^{20,21}$, \\ Travers-Trolet Morgane ${ }^{22}$, Tsagarakis Konstantinos ${ }^{23}$, Van Der Meeren Gro I. ${ }^{24}$, Zador Stephani ${ }^{25}$
}

${ }^{1}$ Sea Around Us Project, University of British Columbia, 2202 Main Mall, Vancouver, BC, Canada V6T $1 \mathrm{Z4}$

${ }^{2}$ National Marine Fisheries Service, Northeast Fisheries Science Center, National Oceanic and Atmospheric Administration, 166 Water Street, Woods Hole, MA 02543, USA

${ }^{3}$ Institut de Recherche pour le Développement, UMR EME 212, Centre de Recherche Halieutique Méditerranéenne et Tropicale, Avenue Jean Monnet, BP 171, 34203 Sète Cedex, France

${ }^{4}$ Centre for Environment, Fisheries \& Aquaculture Science (Cefas), Lowestoft Laboratory, Pakefield Road, Lowestoft, Suffolk NR33 OHT, UK

${ }^{5}$ Bedford Institute of Oceanography, Population Ecology Division, PO Box 1006, Dartmouth, NS, Canada B2Y 4A2

${ }^{6}$ Marine Research Institute and Department of Biological Sciences, University of Cape Town, Private Bag X3, Rondebosch, Cape Town 7701, South Africa

${ }^{7}$ Pacific Biological Station, Fisheries and Oceans Canada, 3190 Hammond Bay Road, Nanaimo, BC, Canada V9T 6N7

${ }^{8}$ Instituto Português do Mar e da Atmosfera (IPMA), Av. de Brasília, 1449-006 Lisboa, Portugal

${ }^{9}$ Centre National des Sciences Halieutiques de Boussoura (CNSHB), sis au 814, Rue MA500, Corniche

Sud Boussoura, BP 3738 Conakry, Republique de Guinée

${ }_{11}^{10}$ Scottish Marine Institute, Dunstaffnage, Oban PA371QA, Scotland

${ }^{11}$ Université Européenne de Bretagne, Agrocampus Ouest, UMR985 Ecologie et santé des écosystèmes, 65 route de Saint Brieuc, CS 8421, 35042 Rennes cedex, France

${ }^{12}$ Scottish Association for Marine Science, Scottish Marine Institute, Oban, Argyll PA371QA, UK

${ }^{13}$ AZTI Tecnalia, Marine Research Division, Herrera Kaia, Portualdea z/g E-20110 Pasaia, Gipuzkoa, Spain

${ }^{14}$ Earth to Ocean Research Group, Simon Fraser University, 8888 University Drive, Burnaby, BC, Canada V5A 1 S6

${ }^{15}$ Institut de Recherche pour le Développement, UMR ECOSYM 238, Labep-AO (IRD-IFAN), BP 1386 Dakar, Senegal

${ }^{16}$ School of Aquatic and Fishery Sciences, University of Washington, Box 355020, Seattle, WA 981955020, USA

${ }^{17}$ Estonian Marine Institute, University of Tartu, Lootsi 2a, 80012 Pärnu, Estonia

${ }^{18}$ Water Resources Unit, Institute for Environment and Sustainability, Joint Research Centre, Ispra, Italy

${ }^{19}$ Instituto del Mar del Perú (IMARPE), Esquina Gamarra y Gral, Valle s/n, Apartado 22, Callao, Lima, Peru

${ }^{20}$ Instituto Español de Oceanografía (IEO), Centro Oceanográfico de Cádiz, Puerto Pesquero, Muelle 
de Levante s/n, P.O. Box 2609, E-11006 Cádiz, Spai n

${ }^{21}$ Swedish University of Agricultural Sciences, Department of Aquatic Resources, Institute of Coastal Research, Skolgatan 6, SE-742 42 Öregrund, Sweden

22 IFREMER Fisheries Laboratory, 150 quai Gambetta, 62321 Boulogne-sur-Mer, France

${ }^{23}$ Hellenic Center for Marine Research, Institute of Marine Biological Resources and Inland Waters, Agios Kosmas, 16610 Elliniko, Athens, Greece

${ }^{24}$ Institute of Marine Science and The Hjort Centre for Marine Ecosystem Dynamics, PB 1870 Nordnes, NO-5817 Bergen, Norway

${ }^{25}$ Alaska Fisheries Science Center, National Marine Fisheries Service, National Oceanic and Atmospheric Administration, 7600 Sand Point Way NE, Seattle, WA 98115, USA

* Corresponding author : Kristin M. Kleisner, email address : k.kleisner@fisheries.ubc.ca

\begin{abstract}
:
Fisheries provide critical provisioning services, especially given increasing human population. Understanding where marine communities are declining provides an indication of ecosystems of concern and highlights potential conflicts between seafood provisioning from wild fisheries and other ecosystem services. Here we use the nonparametric statistic, Kendall's tau, to assess trends in biomass of exploited marine species across a range of ecosystems. The proportion of 'Non-Declining Exploited Species' (NDES) is compared among ecosystems and to three community-level indicators that provide a gauge of the ability of a marine ecosystem to function both in provisioning and as a regulating service: survey-based mean trophic level, proportion of predatory fish, and mean life span. In some ecosystems, NDES corresponds to states and temporal trajectories of the community indicators, indicating deteriorating conditions in both the exploited community and in the overall community. However differences illustrate the necessity of using multiple ecological indicators to reflect the state of the ecosystem. For each ecosystem, we discuss patterns in NDES with respect to the community-level indicators and present results in the context of ecosystem-specific drivers. We conclude that using NDES requires context-specific supporting information in order to provide guidance within a management framework.
\end{abstract}

\title{
Highlights
}

This indicator gauges ability of an ecosystem to sustainably provide wild seafood. This indicator provides a simple way to focus on exploited species in an ecosystem. Multiple drivers of impact necessitate a suite of indicators to provide context.

Keywords : Ecological indicator, Comparative approach, Community metric, IndiSeas, Fishing impacts 


\section{Introduction}

Oceans provide important ecosystem services for human well-being, including provisioning services (e.g., procurement of seafood and medicinal products), regulating services (e.g., moderation of climate fluctuations and protection against flooding and erosion), cultural services (e.g., aesthetic and spiritual benefits, and recreation), and supporting services (e.g., nutrient cycling, carbon storage, and trophic stability) (Worm et al. 2006, Daniel et al. 2012). The provision of seafood from wild capture fisheries is one of the most critical benefits that humans derive from the ocean and as such, the regulation of commercial harvests of fish stocks has become a priority. Additionally, there has been a concerted effort to measure and regulate other ecosystem services that may have negative impacts on fisheries (e.g., balancing conservation objectives underlying ecotourism) through marine spatial planning (Foley et al. 2010), better valuation (Börger et al. 2014) and analyses of the synergies and trade-offs (Halpern et al. 2012) of marine ecosystem services.

However, while declines in some fisheries have been halted or some fish stocks have recovered due to precautionary fisheries management or reduced exploitation rates (Worm et al. 2009), many exploited stocks around the world are in decline due to a combination of stressors such as overfishing, pollution, habitat degradation, and climate change. These stock declines result in fisheries yields, which are less than optimal and ultimately can lead to stock collapse. This is of growing concern due to the direct impacts on food security for over three billion people who rely on fisheries to supply a significant portion of their animal protein (FAO 2014). Fishing represents one of the most significant human impacts on marine ecosystems and has led to many changes including alterations of the trophic structure, declines in the abundance of top predators, biodiversity, and overall resilience and biomass of some ecosystems (Pauly et al. 1998, Jackson et al. 2001, Christensen et al. 2003, Perry et al. 2010, Jackson et al. 2011). Additionally, the spatial footprint of fishing has continued to increase as fisheries have expanded offshore (Coll et al. 2008a, Swartz et al. 2010) and into deeper waters (Morato et al. 2006). These expansions have often been facilitated by the use of increasingly sophisticated fishing technology (Pauly et al. 2002). These remarkable technological improvements have resulted in fleets that are more efficient (Pauly \& Palomares 2010) and more powerful (Anticamara et al. 2011) than at any time in the past. However, this has not led to increased catches but rather a stagnation or even slow decline in the overall global catch (FAO 2014), threatening the delivery of this critical ecosystem service.

Traditionally, fish stocks have been assessed and managed as single units, with little consideration for the linkages with other components of the ecosystem. However, there is a growing push to manage fish stocks cohesively as one aspect of an ecosystem-based approach to marine management (Link et al. 2002, Garcia 2009). This is in line with the objectives of several international conventions such as the Convention on Biological Diversity (CBD 2010) and regional legislations such as the European Marine Strategy Framework Directive (EU Directive 2008/56/EC) or the EU Common Fisheries Policy (European Commission 2013). An ecosystem approach to management requires the development of indicators and robust methods to 
gauge changes in marine ecosystems. This requires indicators of ecosystem change that are easy to interpret in order to measure the impacts of fishing, climate change, and other factors across ecosystems and to provide management guidance at an ecosystem level.

However, the development of robust and reliable marine indicators is still in its infancy, and multiple indicators may be necessary to capture changes in different components of the community and to provide a more complete understanding of ecosystem status (Shin et al. 2010b, Bundy et al. 2012). For example, trophic level indicators calculated for different portions of the ecosystem (e.g., surveyed biomass vs. landings) can provide differing views of the status of the ecosystem (Shannon et al. 2014) and highlight places where trophic instability may be affecting the delivery of provisioning and/or regulating ecosystem services. The need to interpret multiple ecosystem indicators to obtain a more complete understanding of the status of the system is particularly important in an ecosystem services framework since the majority of ecosystem indicators currently available are not comprehensive and are often inadequate to characterize ecosystem services when used alone (Liquete et al. 2013, Piroddi et al. In Review).

Here we test an indicator, which has been proposed as a 'simple community analysis' (Lynam et al. 2010), and which can be interpreted in terms of trends and correlations of multiple species at the community-level, for use as a gauge of the ability of an ecosystem to deliver provisioning services. This measure was originally developed and demonstrated using fish survey and phytoplankton count data from waters off the west coast of Ireland (Lynam et al. 2010). The indicator is based on a nonparametric test statistic, Kendall's tau (Kendall \& Gibbons 1990), which is used to determine the strength of declining or non-declining trends in a set of time series of species biomass from the comparison of theoretical and observed distributions of the statistic. We also assess the proportion of non-declining species across several ecosystems.

Similar to Lynam et al. (2010), we use this statistic in a simple community analysis approach to explore biomass trends for exploited species within ecosystems and to estimate the proportion of non-declining exploited species biomass, the 'NonDeclining Exploited Species' (NDES) indicator. The rationale for exploring nondeclining trends, rather than the proportion of declining trends, is to have an indicator that should have a lower value at higher levels of fishing pressure (i.e., more declining biomass trends with higher exploitation rates), in line with other ecological indicator formulations selected for comparing the effects of fishing across ecosystems (Shin et al. 2010b). Cross-ecosystem comparisons of the NDES indicator are possible because it accounts for the distinct number of species and differing length of the time series data available in each ecosystem. First, we illustrate, based on the full set of single exploited species trends for each ecosystem, the proportion of non-declining species and compare the indicator values between ecosystems. Second, in order to understand the patterns in NDES, which provides information specific to the exploited portion of the community, we compare NDES to three 
community-level indicators that provide a gauge of the ability of a marine ecosystem to function both in a provisioning role and as a regulating service (i.e., through maintenance of biodiversity, trophic stability, and reproductive potential): proportion of predatory fish (PPF), survey-based mean trophic level (TLsc), and mean life span (mLS), which were described by Shin et al. (2010b). In particular, the utility of trophic level indicators for capturing the health and status of different components of the marine community has been explored in detail by Shannon et al. (2014). We use these indicators to determine whether exploited species biomass is associated with other ecosystem-level changes. These particular indicators were selected because (a) data to compute the indicators for each ecosystem were available, (b) they are more integrative as they include all survey species as opposed to looking only at the exploited portion of the community, and (c) they are speciesbased like the NDES, but also account for different functional traits within the greater community. Each of these indicators is also formulated such that greater fishing pressures results in lower indicator scores.

\section{Methodology}

\section{Ecosystems}

We analyze 22 marine ecosystems spanning upwelling, high-latitude, temperate, and tropical marine habitats across the world's oceans (Table 1). They comprise the Barents Sea, the Bay of Biscay, the central Baltic Sea, the eastern Bering Sea, the eastern Scotian Shelf, the English Channel, the Guinean Shelf, the Gulf of Cadiz, the Irish Sea, the north Aegean Sea, the northern Humboldt Current, the north Ionian Sea, north-central Adriatic, the northeast U.S., the North Sea, the Portuguese coast, the south Catalan Sea, the southern Benguela, the Scottish west coast, the U.S. west coast, the west coast of Vancouver Island (hereafter referred to as Vancouver Island), and the western Scotian Shelf. The 22 ecosystems assessed here have been selected because multiple trends of species biomass from biological surveys or stock assessments are available through the IndiSeas international initiative (Shin et al. 2012; www.indiseas.org). The majority of these ecosystems were described and explored in a series of papers resulting from the IndiSeas project (Coll et al. 2010b, Shin et al. 2010b, Bundy et al. 2012). The number of species with biomass time series available for analysis and the average timespan over which the biological surveys and stock assessments were conducted vary greatly between ecosystems (Table 1). The northeast U.S. shelf has both the greatest number of available biomass time series (124) and the longest survey duration (47 years). Conversely, the north Ionian Sea has the fewest number of time series (5) and the north Aegean Sea has the shortest survey duration (4 years). The full list of species assessed in each ecosystem, length of time series, Kendall's tau correlation coefficient of exploited species biomass time series, and the relative proportional contribution of each species' average biomass to the overall average exploited biomass available in each ecosystem is presented in Table S1 in the Supplementary Information.

\section{Calculating the Non-Declining Exploited Species (NDES) indicator}


Lynam et al. (2010) used the Kendall's tau correlation coefficient to quantify the degree of association between the species biomass as measured from a biological survey ( $X$ variable) and the time series of years over which the survey was conducted ( $Y$ variable). Kendall's tau is a measure of the strength of the tendency of these two variables, $X$ and $Y$ to move in the same (or opposite) direction. That is, the estimates of tau in a set of species provide a probability of having a monotonic temporal trend in the biological data. Lynam et al. (2010) noted that one of the strengths of such a rank-based method over other parametric methods (e.g., Pearson's product moment correlation coefficient) is that the relationship between the measured variables does not have to be linear and does not rely on any assumption about the distribution of the variables.

Here, we take the same approach, calculating the Kendall's tau coefficient for each exploited species in an ecosystem with time series of biomass data (Table 1). The rationale is to build an indicator which would be simple to estimate, and easy to communicate, reflecting what proportion of exploited species have their biomass increasing or decreasing in each ecosystem, potentially as a result of fishing. Each tau is calculated by examining the difference between consecutive years and the corresponding consecutive biomass values (Lynam et al. 2010). If the differences are both positive, then this demonstrates an increase in biomass. By looking at all pairs in a time series within an ecosystem, one can determine whether the biomass over the time series is generally increasing or decreasing. The higher the proportion of concordant or discordant pairs, the stronger the increase or decrease, respectively. This procedure results in a measure of the probability of an increasing biomass trend (tau) for each exploited species from biological surveys or stock assessments in an ecosystem. A histogram of the resulting distribution of all Kendall's tau coefficients within an ecosystem allows a comparison of the observed distribution of tau with the theoretical expected distribution to assess whether there is a significant monotonic trend. An observed distribution of the statistic tau that is shifted to the left of the expected theoretical distribution indicates an ecosystem with more species with declining biomass than expected by chance alone. The converse is true for an observed distribution shifted to the right of the expected theoretical distribution.

Because we are interested in determining whether the NDES indicator is significantly high (i.e., more non-declining trends) or low (i.e., more declining trends), we formally test whether the observed distribution of the statistic tau is shifted to the right or left of the theoretical expected distribution with a two-tailed nonparametric Kolmogorov-Smirnov (KS) single-sample goodness-of-fit test. The null hypothesis tested is that there is no difference between the observed distribution and the expected distribution. The KS significance test takes into account the number of species and the differing length of the time series in the calculation of the theoretical expected distribution (red line in Figure 1). An ecosystem with few species trends, but a long time series will have a more leptokurtic distribution than an ecosystem with few species trends with short time 
series. The proportion of non-declining biomass of exploited species out of the total number of exploited species biomass trends in an ecosystem (as determined from this method) is taken to be the state indicator we call 'Non-Declining Exploited Species' (NDES).

Kendall's tau and associated analyses were conducted in R version 3.0.2 (R Core Team 2013) using the packages 'stats', and 'SuppDists' (Wheeler 2009).

\section{Supplemental community-based indicators}

We conducted several analyses to compare the NDES indicator directly with the status and trends of three other community indicators including proportion of predatory fish (PPF), average trophic level of the surveyed community (TLsc), and mean lifespan (mLS). These indicators were selected from the set of IndiSeas indicators chosen according to a carefully defined set of criteria (Shin et al. 2012) because they were available for the majority of the ecosystems presented here. Additionally, they are important indicators of ecosystem status and trend and have been noted to be effective at capturing different aspects of ecosystem functioning such as the state of turnover processes, predator-prey dynamics, and trophic composition (Shin et al. 2010b, Shin \& Shannon 2010, Bundy et al. 2012, Shannon et al. 2014). The PPF is calculated as the ratio of the biomass of predatory fish species surveyed to the total biomass surveyed and TLsc is calculated as the biomassweighted average trophic level of the total surveyed community. The PPF and TLsc are designed to capture the effect of fishing on larger and higher trophic level species in the ecosystem. The mLS is calculated as:

$$
\sum_{s}\left(\operatorname{age}_{M A X, s} \cdot B_{s}\right) / \sum_{s} B_{s}
$$

where $B_{S}$ is the survey biomass estimate for a given species $s$ and $a g e_{M A X, S}$ is the maximum longevity of the species. This indicator is used as an inverse proxy for turnover rate and conveys the idea that fishing favors the emergence of species with a short lifespan (Shin et al. 2010b). The three indicators hence reflect changes in different facets of functional diversity (Bundy et al. 2010) and capture more of the ability of the ecosystem to act in a regulating role through the maintenance of biodiversity, trophic stability, and reproductive potential.

In contrast to the NDES indicator, which looks specifically at the biomass of the exploited component of the ecosystem, mLS, PPF, and TLSc, are calculated on the full suite of surveyed species biomass (i.e., surveyed biomass of exploited and nonexploited species) in a given ecosystem (Shin et al. 2010b). Because the indicators were designed to capture different components of the state of the ecosystem, we do not necessarily expect to find correlations between the indicators, but we illustrate similarities and differences between the indicators and provide some context for the patterns observed in each ecosystem. 
First, for each ecosystem we compare the NDES indicator with the current state of each of the community indicators (PPF, TLsc, and mLS) using petal plots. The state for each of the three community indicators is calculated as the average of the most recent five years for which data were available (for most systems this was 20062010). Thus, the 'current state' of the ecosystem with regard to these three community indicators is compared directly with the NDES indicator (i.e., the proportion of exploited species with non-declining biomass in each ecosystem). For each of the 22 ecosystems the values for the four indicators are rescaled between 0 (worse state) and 1 (better state) in order to allow for comparison between indicators and between ecosystems. Each of the indicators used in the analyses presented here are designed such that higher fishing pressure should result in a lower indicator score (Shin et al. 2010b).

Next, for each ecosystem, we also evaluate the correlation over time of the three ecosystem indicators (PPF, TLSc, and mLS) with the biomass time series for each exploited species that were used to calculate the NDES. We perform this comparison again using the Kendall's tau correlation coefficient to quantify the degree of association between the times series of exploited species biomass from the survey (X variable) and each time series of ecosystem indicator values (Y variable). These comparisons are calculated for all years in which both biomass values and ecosystem indicator values exist. Here, in contrast to the Kendall's tau calculated for the NDES indicator, we used a two-tailed binomial test to assess the significance of the hypothesis that there are more positive or negative correlations between the biomass trends and the three community indicator values than would be expected by chance. Because we are looking at pairwise changes in the community indicator values and the biomass of an exploited species, we are assessing the trajectories of the time series, rather than correlating linear trends (i.e., slopes). A positive correlation indicates that the exploited biomass trends are following the same trajectory as the community indicator trends (i.e., increasing or decreasing). We present the proportion of positively correlated trends per ecosystem and term proportions greater than 0.5 'positively correlated' (i.e., more similar trajectories) and proportions less than 0.5 'negatively correlated' (i.e., more opposing trajectories). In order to determine whether the community indicators are positively or negatively correlated to biomass trends (i.e., decreasing/increasing community indicator associated with decreasing/increasing biomass trends), we calculate the slopes of each of the community indicators based on the complete time series of normalized indicator values (i.e., standardized by subtracting the mean and dividing by the standard deviation) for each ecosystem using generalized least-squares models with autoregressive errors following Blanchard et al. (2010). These slopes are used to further investigate the relationships between the trends in exploited species biomass and the community indicators.

Finally, in order to better understand the state and trend patterns in the NDES indicator and the three community indicators, we examine the biomass trends of the exploited species within an ecosystem with respect to the species trophic level (local 
values provided by IndiSeas experts or determined from FishBase, www.fishbase.org, see Table 1S). The rationale for this exploration is to evaluate whether there is a greater proportion and number of declining trends for lower or higher tropic level species. Thus, we compute the biomass-weighted average trophic level of the exploited species with declining biomass and compare that to the biomass-weighted average trophic level of the exploited species with non-declining biomass in a given ecosystem. Because each ecosystem will have a different composition of species with varying trophic levels that is related to factors specific to the particular ecosystem (e.g., levels of primary productivity, exploitation history, oceanography, etc.), we define 'lower' or 'higher' trophic levels on a relative basis within an ecosystem, and we do not compare these values between ecosystems. However, we explore whether ecosystems with a higher proportion of declines of higher trophic level exploited species tend to have lower scores for the ecosystem indicators.

\section{Results \& Discussion}

\section{The Non-Declining Exploited Species (NDES) Indicator}

Histograms of Kendall's tau statistic indicate the distribution of negatively (decreasing; white portion of histogram bars) and positively (increasing; grey portion of histogram bars) correlated biomass trends for the exploited species in each ecosystem (Figure 1). Based on the proportion of non-declining trends (i.e., the NDES indicator), we find that in 10 out of the 22 ecosystems, more than half of the exploited species trends are significantly non-declining (Table 1; NDES $>0.5, p$ value $<0.05$ ). Most biomass trends are not declining for exploited species (i.e., higher NDES values) in the English Channel, the south Catalan Sea, the eastern Bering Sea, the southern Benguela, the western Scotian Shelf, the North Sea, the northeast U.S., Vancouver Island, the Portuguese coast, and the Barents Sea (ordered from lower to higher NDES values). We find that the observed values of the tau statistic in these ecosystems are shifted to the right of the expected theoretical distributions (red lines), indicating that there are fewer species declining in biomass than should be expected by chance alone.

Nine ecosystems have significantly more species that show declining biomass trends (Table 1; NDES $<0.5, p$-value $<0.5$ ), including the Guinean Shelf, the north Ionian Sea, the Gulf of Cadiz, the Bay of Biscay, the north-central Adriatic, the eastern Scotian Shelf, the Irish Sea, the U.S. west coast, and the north Aegean Sea (ordered from lower to higher NDES values). We find that the observed values of the tau statistic in these ecosystems are shifted to the left of the expected theoretical distributions (red lines), indicating that there are more species with a declining biomass than should be expected by chance alone. Note that the U.S. west coast and the north Aegean Sea ecosystems have relatively short time series ( 8 and 4 years, respectively), which results in expected theoretical distributions of the tau statistic that are broader and flatter compared with the rest of the ecosystems. It is expected 
that the variance of the expected distributions of the tau statistic should increase as the length of the time series of biomass decreases, which is a weakness of the indicator. The NDES indicator is non-significant in the central Baltic Sea, the northern Humboldt Current, and the Scottish west coast.

\section{Comparison of the NDES indicator with community status indicators}

The current status for the three community indicators and the NDES indicator vary greatly among ecosystems (Figure 2). In some ecosystems, the scores for all four indicators are relatively high (e.g., the eastern Bering Sea, the northeast U.S. and Vancouver Island) suggesting these ecosystems have a better ecosystem state overall. In other cases, the scores are all relatively low (e.g., the central Baltic Sea, the Gulf of Cadiz, the Irish Sea, the north Ionian Sea, the north Aegean Sea, and the northern Humboldt Current), suggesting a worse ecosystem state on average. For other ecosystems the NDES indicator contrasts with the results of the communitylevel indicators (e.g., the Bay of Biscay) suggesting that patterns in the exploited portion of the community are not reflected in the whole community.

The composition of the trophic levels of the species that are declining within an ecosystem can provide some insight as to why the NDES scores might be higher or lower than the status of the community indicators (Figure 3) and can help illustrate the similarities between the patterns in the exploited species versus the whole community. For example, the north-central Adriatic receives a high score for TLsc. However, the proportion of non-declining species is 29\%, resulting in a low NDES score. This discrepancy can be explained by the fact that the biomass-weighted average trophic level of the declining species is lower $(\sim 3.1)$ relative to the biomassweighted average trophic level of the species that are not decreasing $(\sim 3.75)$, indicating that lower trophic level species in the system are the ones declining and resulting in a higher TLsc. However, the fact that the average trophic level of these species is less than 4 suggests that large predatory fish are not abundant in the north-central Adriatic, which may point to why the scores for PPF and mLS are also lower (Coll et al. 2009, Coll et al. 2010a). Similar trophic level patterns are found for the Bay of Biscay, which is strongly over-exploited (Guénette \& Gascuel 2012) and where the PPF status is high relative to the lower scores for the NDES indicator. These discrepancies can be explained by the fact that the biomass of lower trophic level species is declining.

The north Ionian Sea has the lowest status scores (i.e., 0) for the three community indicators and the NDES indicator. In this ecosystem, there are few exploited biomass trends, which are used to calculate the NDES indicator and all are declining according to the Kendall's tau statistic (Figure 1, Table 1). Additionally, the average trophic level of the exploited biomass is around 3.2, which is relatively low. This ecosystem, like many regions in the Mediterranean (e.g., south Catalan Sea: Coll et al. 2008 b), is dominated by lower trophic level organisms (especially invertebrates and small pelagic fish) due to historic and current heavy fishing pressure (Piroddi et al. 2010). This situation also occurs in other heavily exploited Atlantic ecosystems, for 
example in the Gulf of Cadiz (Torres et al. 2013). The reduction in the trophic level of the overall ecosystem is reflected in the low status of the community indicators.

The Barents Sea provides an example of a higher score for the NDES indicator and a lower score for the community indicators. In the Barents Sea, nine out of 11 biomass trends are non-declining and the biomass-weighted average trophic level of the declining exploited species is lower. In this case, the NDES indicator does not reflect what is happening in the overall system. However, the Barents Sea is an ecosystem where stocks of short-lived small capelin (Mallotus villosus) and transient stocks of young herring (Clupea harengus, 0-4 years old) are major drivers for the top predators (Hjermann et al. 2010, Johannesen et al. 2012). These stocks show large natural fluctuations over relatively short time periods. During the 38 years of survey data analyzed here, capelin has fluctuated between very low biomass levels (Gjøsæter et al. 2009) and the highest peak in history (within the last 10 years) followed by natural declines one to two years after each peak. This pattern is likely causing a temporary reduction in the TLsc even if the long-lived, top predator species show a concurrent increase over the same period. Similar to the Barents Sea, the NDES scores for the Portuguese coast, southern Benguela, and the south Catalan Sea are also higher than the status of the community indicators, with fewer declining species trends. However, in these cases there are fewer declining exploited biomass trends, and it is mainly biomass of higher trophic level fish that is decreasing (Figure 3), corresponding to the lower scores for TLsc, PPF, and mLS, and in line with independent observations (e.g., the south Catalan Sea: Coll et al. 2008b).

For the English Channel and the western Scotian Shelf, there are more exploited species biomass trends that are not declining, but there is still a relatively large number of declining species compared to other ecosystems. In both ecosystems, the declining species have a lower average trophic level. For the western Scotian Shelf, the average trophic level of the species that are not declining is $>4$, corresponding to a higher TLsc, which is at odds with the low scores for PPF and mLS. This is because Atlantic herring (Clupea harengus), a declining, exploited species with a relatively low trophic level, constitutes a large part of the surveyed biomass $(\sim 68 \%$, Table S1). Conversely, for the English Channel, the PPF score is very high, especially given the fact that the average trophic level of the declining and non-declining species is lower and quite similar $(\sim 3.5$ versus $\sim 3.75)$. The fact that the average trophic levels of the declining and non-declining species are lower corresponds with the lower mLS and TLsc. Additionally, the English Channel is characterized by a regime shift that affected the fish community in mid-1990s, which was illustrated both by a declining biomass of small forage fish and an increasing biomass of large demersal fish (Auber et al. Submitted).

In some cases, the trophic level of the declining species does not adequately explain the discrepancy between the NDES indicator scores and the three community indicators. For example, on the U.S. west Coast, the biomass-weighted average trophic level of the declining species is close to that of non-declining species. 
However, declining trends in biomass and mean trophic level of the surveyed species have been attributed to climate variability and attenuating mortality of a strong 1999 year class for multiple species targeted by the groundfish fishery (Keller et al. 2012, Tolimieri et al. 2013). Because overfishing is not the main driver of the trends in biomass, it is not surprising that the four indicators do not show perfect correlations. The score for mLS is very high due to long-lived rockfish species. In contrast the scores for the NDES, PPF, and TLsc indicators are lower compared to other ecosystems. Lower PPF and TLsc scores are due in part to the three most abundant species in the survey: Pacific hake (Merluccius productus), Dover sole (Microstomus pacificus), and longspine thornyhead (Sebastolobus altivelis). The diet of Pacific hake is dominated by euphausiids (Robinson 2000), while Dover sole and longspine thornyhead consume primarily benthic invertebrates (Gabriel \& Pearcy 1981, Rooper \& Martin 2009)-none of these species are considered predatory by the PPF index. For the Guinea Shelf, the scores for PPF are higher than the other indicators, although the scores across all indicators are quite low. The low score for the NDES indicator is a result of declines in all 20 biomass trends available. The biomass-weighted average trophic level of these declining species is just under 3.5, which corresponds to the low TLsc and mLS scores, but suggests that the PPF score should be lower.

There are three ecosystems for which the NDES indicator is not significant: the central Baltic Sea, the northern Humboldt Current, and the Scottish west coast. The NDES indicator for each of these ecosystems is close to 0.5 , indicating that the proportions of increasing and decreasing exploited species are relatively even. In the central Baltic Sea and the northern Humboldt Current, the NDES indicator has a higher status than the community indicators. In the central Baltic Sea, lower trophic level clupeids (sprat and herring) are the dominant species in the system in terms of overall abundance (Eero 2012). In contrast, there is only one abundant higher trophic level predatory marine fish (Atlantic cod, Gadus morhua), which is also the most valuable and therefore heavily exploited species in the Baltic, and moreover subject to climate-related fluctuations (Eero et al. 2011). A possible explanation for the lower PPF and TLsc scores in the central Baltic is the climate-initiated regime shift in this ecosystem at the end of the 1980s, which resulted in a strong decrease in the cod population and a substantial increase in the abundance of clupeids likely due to reduced predation by cod (e.g., Möllmann et al. 2009, Eero 2012, Tomczak et al. 2013).

Similarly, for the Northern Humboldt, the decrease in mLS and TLsc during the study period responds to the recovery of the short-lived anchoveta (Engraulis ringens) after El Niño 1997-98. Because of the dominance of this species in this upwelling ecosystem, a reduction of mLS and TLsc likely corresponds to an increase in ecosystem health, highlighting the need for a context-specific approach to interpreting these indicators. In contrast, on the Scottish west coast, no regime shift has been identified, but large demersal fish (haddock: Melanogrammus aeglefinus, pollack: Pollachius pollachius, squids: Lophius species, flatfishes: Pleuronectiformes) and predators (rays and skates) have also shown an increase in the late 1990s 
(Bailey et al. 2011, Alexander et al. In Press). These increases occurred in the absence of large declines in important small forage fish species such as herring and mackerel (Scomber scombrus and Trachurus trachurus), although sprat (Sprattus sprattus) and sandeels (Ammodytes tobianus) have declined.

\section{Comparison of the NDES indicator with community indicator trends}

Comparing the exploited single species biomass trends directly with the trends in the three ecosystem indicators, i.e., PPF (Figure 4), TLsc (Figure 5), mLS (Figure 6) we obtain insights as to which ecosystem indicators are positively or negatively correlated with the NDES indicator. An understanding of the direction of the correlation between the community indicators and the exploited species biomass trends allows us to determine whether the patterns in the exploited community are reflected in the overall community (i.e., a positive correlation). When there are negative correlations between the NDES and the community indicators, this may be an indication that different pressures or drivers (e.g., climate change) may be affecting different segments of the community. We explore this possibility in the context of the trophic structure of the exploited community (i.e., Figure 3).

Additionally, we explore the overall significance of the temporal trend in each of the community indicators for each ecosystem. When we see significant trends in the indicator time series, we can directly infer the relationship between correlations in the exploited species biomass time series and the ecosystem indicator of interest, i.e., whether patterns in the exploited community are also picked up in the overall community.

The PPF is significantly positively correlated with the majority (i.e., more than half) of exploited species biomass trends in 16 ecosystems (Table 2, Figure 4). This suggests that the trajectory of exploited species biomass corresponds to the trajectory of the proportion of predatory fish in these ecosystems. These positive correlations occur in the Barents Sea, the eastern Bering Sea, the eastern Scotian Shelf, the English Channel, the Gulf of Cadiz, the Irish Sea, the north Aegean Sea, the northern Humboldt Current, the north Ionian Sea, the north-central Adriatic, the North Sea, the southern Benguela, the south Catalan Sea, the U.S. west coast, Vancouver Island, and the western Scotian Shelf. For three of these ecosystems, the Barents Sea, the English Channel, and the western Scotian Shelf, the trend in PPF is significantly increasing (Figure 7) and most of the exploited biomass trends are also increasing (Table 1, NDES: 0.82, 0.55 and 0.60 for the Barents Sea, the English Channel, and the western Scotian Shelf, respectively). Similarly, for the eastern Scotian Shelf, the northern Humboldt Current, the Gulf of Cadiz, and the north Ionian Sea, less than half of the exploited species biomass trends are declining (Table 1 , NDES: $0.37,0.40,0.08$, and 0 , respectively). For the southern Benguela and the south Catalan Sea, the linear trend in PPF is significantly decreasing (Figure 7), but the majority of exploited species have positive biomass trends (Figure 1). This discrepancy is better explained by the fact that the exploited species with declining biomass in these ecosystems have higher average trophic levels than the nondeclining exploited species (Figure 3). For ecosystems with a significant trend in the 
NDES indicator based on the $p$-value of the Kendall's tau statistic (Table 1), but without a significant relationship in the PPF trend (the eastern Bering Sea, the Gulf of Cadiz, Irish Sea, north Aegean, and U.S. west coast), a signal may be present in the exploited portion of the community that is masked in the overall community. For example, in the eastern Bering Sea, changes in climatic patterns that have influenced summer bottom temperatures have been associated with declines in commercially exploited Alaska pollock (Theragra chalcogramma), and increases in predatory arrowtooth flounder (Atheresthes stomias), for which there is little commercial exploitation (Zador et al. 2011, Hunsicker et al. 2013).

Four ecosystems: the Bay of Biscay, the Guinean Shelf, the northeast U.S., and the Scottish west coast, have negative correlations between PPF and the available biomass trends (i.e., less than half of the exploited species biomass trends are positively correlated with PPF; Table 2, Figure 4). This suggests that the trajectory of exploited species biomass contradicts the trajectory of the proportion of predatory fish in these ecosystems. There is a significant decreasing trend in the PPF indicator over time for the northeast U.S. (Figure 7) and more exploited species that are not declining (Table 1, NDES: 0.75). Conversely, there is a significant increasing trend in PPF for the Scottish west coast (Figure 7) and more exploited species that are declining (Table 1, NDES: 0.45). The biomass-weighted average trophic levels corroborate these patterns (Figure 3). For the northeast U.S., although there are fewer species with a declining biomass, the average trophic levels of both the declining and non-declining species are relatively high $(\sim 4)$, suggesting that there is a greater proportion of higher trophic level predatory fish are experiencing declines. For the Scottish west coast, the biomass-weighted average trophic level of the declining exploited species is lower than the non-declining species, suggesting that higher trophic level species are being less affected by fishing or other drivers. This is likely due to the introduction of the cod recovery plan in 2004 (EU 2004), which reduced direct fishing mortality on demersal fish in the mixed fishery, although it did not have the intended effect of an increase in the cod stock on the Scottish west coast (Bailey et al. 2011, Alexander et al. In Press).

The trophic level of the surveyed community (TLsc) indicator is significantly and positively correlated with the biomass trends in 9 ecosystems (Table 2, Figure 5): the Bay of Biscay, the eastern Scotian Shelf, the English Channel, the Guinean Shelf, the Irish Sea, the north-central Adriatic, the south Catalan Sea, the U.S. west coast, and Vancouver Island. This suggests that the trajectory of exploited species biomass corresponds to the trajectory of the average trophic level of the surveyed community in these ecosystems. The NDES is higher in the English Channel, the south Catalan Sea, and Vancouver Island (Table 1, NDES: 0.55, 0.56, and 0.77, respectively). However, there are no significant trends in the normalized TLsc time series for these three ecosystems (Figure 7). There are significant negative correlations in the TLsc time series for the eastern Scotian Shelf, the north-central Adriatic, and the U.S. west coast, confirming the positive correlation between exploited species with declining biomass trends and declining TLsc. Additionally, for the eastern Scotian Shelf and the U.S. west coast, the biomass-weighted mean 
trophic level of the declining species is slightly higher than the biomass-weighted mean trophic level of the non-declining species (Figure 3).

The TLsc indicator is significantly and negatively correlated with the exploited species biomass trends in eight ecosystems: the eastern Bering Sea, the Gulf of Cadiz, the northern Aegean Sea, the north Ionian Sea, the northeast U.S., the North Sea, the southern Benguela, and the western Scotian Shelf (Table 2, Figure 5). This suggests that the trajectory of exploited species biomass contradicts the trajectory of the average trophic level of the surveyed community in these ecosystems. There are more exploited species with declining trends in the Gulf of Cadiz, the north Aegean Sea, and the north Ionian Sea (Table 1, NDES: 0.08, 0.44, and 0, respectively). The normalized time series trend in TLsc is significantly increasing only for the north Ionian Sea and the western Scotian Shelf. For the western Scotian Shelf, examining the biomass-weighted average trophic level does not provide an explanation for the negative correlation between the exploited biomass trajectories and the TLsc trajectories. In this case the average trophic level of the declining species is lower (Figure 3) due to the high proportion of herring in the biomass, which supports the significant declining slope of the TLsc trend in this ecosystem. There are significant declining trends in the normalized time series of TLsc for the southern Benguela and the North Sea, supporting the negative correlation between the exploited biomass trajectories (Table 1, NDES: 0.59) and the TLsc trajectories. Additionally, the biomass-weighted average trophic level of the declining species is higher than that of the non-declining species in both of these ecosystems, suggesting that the patterns in the exploited species are mirrored in the community indicator.

The mean life span (mLS) indicator is significantly positively correlated with the biomass trends in nine ecosystems (Table 2, Figure 6). This suggests that the trajectory of exploited species biomass corresponds to the trajectory of the mean life span in these ecosystems. In the eastern Scotian Shelf, the Guinean Shelf, the Gulf of Cadiz, the northern Humboldt Current, and the north Ionian Sea ecosystems the NDES indicator is lower (Table 1 , NDES: $0.37,0,0.08,0.40$, and 0 , respectively), and we see significant declines in the slopes of the trends for $\mathrm{mLS}$ for all of these systems, with the exception of a non-significant decline for the Guinean Shelf (Figure 7), confirming the positive correlations found with the Kendall's tau analyses. There are more non-declining trends in the English Channel, the northeast U.S., the southern Benguela, and the south Catalan Sea (Table 1, NDES: 0.55, 0.75, 0.59, and 0.56 , respectively). In the northeast U.S., there is a lower proportion of declining exploited species (Table 1, NDES: 0.25) and the trend in mLS is increasing significantly (Figure 7), confirming the positive correlations found with the Kendall's tau analyses. However, for the Southern Benguela, there are more nondeclining exploited species (Table 1, NDES: 0.60), but a significantly declining mLS trend (Figure 7). A possible explanation is that the exploited species with a declining biomass have higher trophic levels, corresponding to the decline in mLS over time, and possibly reflecting the observed declines in abundance of some K-selected species off South Africa's west coast (Atkinson et al. 2012). 
The mLS is negatively correlated with biomass trends in eight ecosystems (Table 2; Figure 6). Six ecosystems have significant negative correlations: the eastern Bering Sea, the Irish Sea, north Aegean Sea, the north-central Adriatic, the North Sea, the Scottish west coast, the U.S. west coast, and the western Scotian Shelf. This suggests that the trajectory of exploited species biomass contradicts the trajectory of the mean life span in these ecosystems. In the eastern Bering Sea, the North Sea, and the western Scotian Shelf, the NDES is higher (Table 1, NDES: 0.59, 0.73, and 0.60, respectively). The linear slopes of the $\mathrm{mLS}$ are only significant for the north-central Adriatic, the Scottish west coast, and the western Scotian Shelf (Figure 7), and in each of these cases the slopes are positive. In the case of the western Scotian Shelf, where we have fewer declining exploited biomass trends (Table 1, NDES: 0.60) and a positive linear trend in $\mathrm{mLS}$ (Figure 7), we expect a positive correlation from the Kendall's tau analysis. However, the fact that the biomass-weighted average trophic level of the non-declining species is much higher ( $\sim 4.2$ versus $\sim 3.3)$ could be contributing to longer life spans if higher trophic level species are correlated with higher life spans (Figure 3). For the north-central Adriatic and the Scottish west coast, the proportions of non-declining species are low (Table 1, NDES: 0.29, and 0.45 , respectively). Similar to the western Scotian Shelf, the proportion of lower trophic level species is declining, which could be contributing to longer life spans. However, in the case of the Scottish west coast, another explanation is that there has been an increase in higher trophic level species due to reduced fishing (EU 2004).

\section{Conclusions}

The NDES allows us to assess the proportion of declining species in an ecosystem and provides a useful measure with which to gauge the ability of a marine ecosystem to sustainably provide wild seafood. Given the importance of seafood to provide critical sustenance for humans is of growing concern (Barrett 2010, Garcia \& Rosenberg 2010, Srinivasan et al. 2010, Barange et al. 2014), the NDES may be used as a simple indicator to identify areas where the delivery of this food provisioning ecosystem service is declining or is already in jeopardy. Simple ecosystem indicators such as this have the potential to be used in regions with more robust fisheries management, as well as in regions that are considered to be datalimited and limited in resources and expertise to provide well-founded management advice. In regions with robust fisheries management, ecosystem indicators such as NDES serve an important role in providing a measure of overall ecosystem health, which is critical given that most fisheries management advice continues to be delivered on a single stock basis despite global rhetoric about intentions to adopt ecosystem based management. In regions with less robust fisheries management, the value of NDES cannot be understated. Such a simple indicator, even if calculated with only a limited number of trends, can provide some guidance on status where one may not have been previously available.

It is important to note that the number and length of available species biomass time series may influence the proposed indicator. The comparisons made here are over 
the length of the surveys or assessments that are available in each ecosystem. For the 22 ecosystems presented this represents an average of 27 years, but can be as many as 45 years (northeast U.S.) and as few as four (north Aegean Sea). One of the strengths of Kendall's tau is that the length and number of time series is accounted for in the significance test. However, there may also be situations where biomass trends are variable over the length of the time series. In the Bay of Biscay for example, horse mackerel (Trachurus trachurus) declined strongly from the early 1970 s to the early 1980 s where it remained stable until the early 2000s, when it began to strongly increase. In cases such as these, the determination of a declining trend will come down to the proportion of concordant versus discordant pairs, a result that may not be optimal in cases where there are opposing trends over the time series. Overall, the NDES may not always be an appropriate indicator, given that 1) longer time series data likely have a higher probability of containing opposing trends in species biomass and 2) shorter time series have a larger variance in the tau distribution and trends are more difficult to detect than for longer time series. However, a subset of years from a longer time series can be selected to best reflect the current status of the ecosystem.

Here we illustrate, through a direct comparison of the 'current status' of three community indicators and the NDES indicator, that many declining biomass trends can point to declining TL, lower mLS, and lower PPF (or the converse), highlighting similar patterns in the delivery of both provisioning and regulating services of the ecosystems. This may make intuitive sense if the exploited portion of the ecosystem is tracking what is happening at the community level. However, in some cases, the patterns among these community-level indicators do not agree (e.g., there is a low proportion of species with declining biomass but the mean trophic level of the surveyed community is low). This may be because the NDES indicator is calculated using the full time series available for each exploited species to provide a state indicator, whereas the current status for the community indicators is calculated over the most recent five years and for both exploited and non-exploited species. However, in cases where there is a difference in the status of the community indicators and the NDES indicator, we find it is critical to explore which components of the ecosystem are actually declining. One way to do this is to examine the proportion of declining species in the context of trophic level. Here, we find that in some cases, discrepancies between the directions of the indicators can be explained by looking at the biomass-weighted average trophic level of the declining component of the ecosystem. In general, many declines in higher trophic level exploited species correspond to lower scores for the proportion of predatory fish (PPF) and the trophic level of the surveyed community (TLSc), and to a lesser degree lower mean life span (mLS) suggesting that the pattern captured in the exploited biomass is also observed at the community level. In other cases, in ecosystems driven by lower trophic level fish rather than top-down predation pressure, a high score of NDES may occur with an increase in PPF and a relatively low TLsc (e.g., the north Ionian Sea). In some cases, this happens where lower trophic level species dominate the proportion of exploited species, such as in upwelling systems (e.g., several upwelling systems and many of the Mediterranean systems have low scores 
for current state of community indicators). Since the NDES and biomass trends of exploited species are species-weighted whereas mLs, PPF and TLsc are biomassweighted indicators, we may expect to find some discrepancies in trajectories and seemingly inconsistent correlations.

Additionally, for some regions, stock assessment biomass estimates may provide a better indication of population trends than survey biomass estimates (i.e., some surveys were not designed to sample all species in the community with equal efficiency and some species are assessed using alternate survey data). For example, standard surveys were not conducted in the eastern Bering Sea until a few years after a regime shift. Thus, the survey time series captures the decline from the peak abundance of Alaska pollock that followed the regime shift, whereas the stock assessment, which incorporates alternate survey data, provides a time series of abundance that precedes the regime shift.

Similarly, using the Kendall's tau to examine the correlation between ecosystem indicators and the exploited biomass trends in a system allows one to understand whether patterns in exploited species biomass match trajectories in indicators designed to look at the fuller (exploited and non-exploited) community. Again, ancillary information, such as the average trophic level of the declining exploited species and the direction of significant trends in the ecosystem indicators, can explain what drives the relationships between the NDES indicator and other indicators.

A major finding of our analysis is that the multiple impacts of fishing (and other drivers) on marine ecosystems are difficult to track and assess concomitantly with any single indicator since multiple drivers from fishing to climate and habitat destruction are acting at multiple scales and on multiple processes in ecosystems. Therefore, it is important to explore a suite of indicators and their associations (Blanchard et al. 2010, Shannon et al. 2010, Shin et al. 2010b). The NDES indicator can provide a simple way to focus on exploited species and, through comparisons with community indicators, evaluate the significance of such trends at the community level. Furthermore, the indicator does not make naive assumptions that all species should be declining or increasing but compares the proportion declining against the overall pattern. In developing the NDES, we have included the assumption that in an 'healthy' ecosystem the number of species showing biomass declines should on average be balanced by species showing increases (over the relevant timeframe). It is also imperative to identify which key abiotic conditions and biological groups in the ecosystem are changing to determine the potential impact of the change on the food web. The use here of the community-level indicators provides information on the ability of the ecosystems to deliver regulating services such as maintenance of biodiversity, trophic stability, and reproductive capability. These results illustrate the need to understand the exploitation strategy and long-term dynamics of marine ecosystems and ocean and climate forcing and variability when interpreting such ecosystem indicators. This 
has been illustrated with trophic level-based indicators (Shannon et al. 2014, Gascuel et al. In press).

The ecological status of marine exploited resources is affected by fishing activity; it can also be strongly dependent on the environment. IndiSeas has collated information on several environmental and climate indicators, such as sea surface temperature (SST) and chlorophyll-a densities, which can help clarify the roles that climate and the environment play on the ecological status of marine exploited resources (Shin et al. 2012). These indicators are used to reflect the production potential of ecosystems and thus may reflect more of the supporting role of ecosystems. Additionally, IndiSeas uses human dimension indicators in order to evaluate the human side of fisheries activities, and benefits to society (Shin et al. 2012). The following are considered: 1) effectiveness of fisheries management and quality of governance; 2) contribution of fisheries to the broader society; and 3) wellbeing and resilience of fishing communities. While the focus here was on the development of a specific indicator to evaluate changes in a provisioning ecosystem service (and comparisons with indicators that capture more of the regulating role of ecosystems), it would be of great interest to explore the broader set of indicators in conjunction with NDES to evaluate the tradeoffs and synergies between other regulating, supporting, or cultural ecosystem services.

When multiple ecosystem indicators are used to evaluate patterns of change, it is important to recognize that some indicators are likely to reflect one aspect of the ecosystem more clearly (e.g. fishing), while others may respond to other processes (e.g., climate change, habitat destruction), and thus proffer confounding assessments (Shin et al. 2010a). In such cases, the use of expert judgment (such as that employed in this project in which local experts provide insights into interpretation of the indicator trends in the context of their ecosystems) to evaluate overall ecosystem health will be beneficial. Conversely, the NDES indicator and its associated histogram of tau scores can provide useful information to understand patterns in other trend-based community-level indicators. For example, if the mean trophic level of a community is increasing, it is useful to know if there is an unexpectedly large proportion of lower trophic level species declining, rather than the inferred increase in higher trophic level species. This has been already observed in ecosystems with a high exploitation level of small pelagic fish and invertebrates, such as in the Mediterranean Sea and the southern Benguela (Coll et al. 2010b, Piroddi et al. 2010, Shannon et al. 2010). Therefore, we conclude that using ecological indicators, including the NDES indicator, requires context-specific supporting information in order to provide guidance within a management setting, but that it can provide a valuable and relatively easy to understand indicator. Given its utility to measure the ability of the ecosystem to deliver seafood, further work will be necessary to explore this indicator in relation to the social, economic, governance, environmental, and other ecological attributes of exploited marine ecosystems to provide a more holistic analysis of their overall health and functioning. 


\section{Acknowledgements}

We would like to thank the IndiSeas Working Group, endorsed by IOC-UNESCO (www.ioc-unesco.org) and the European Network of Excellence Euroceans (www.eur-oceans.eu). KK was supported by Conservation International and the Sea Around Us project, a collaboration between The University of British Columbia and The Pew Charitable Trusts. MC was partially supported by the EC Marie Curie CIG grant to BIOWEB and the Spanish Research Program Ramon y Cajal). LJS was supported through the South African Research Chair Initiative, funded through the South African Department of Science and Technology (DST) and administered by the South African National Research Foundation (NRF). YJS and MT were supported by the French project EMIBIOS (FRB, contract no. APP-SCEN-2010-II). LJS and YS were also funded by the European collaborative project MEECE - Marine Ecosystem Evolution in a Changing Environment - (FP7, contract $\left.n^{\circ} 212085\right)$. CPL was supported by Defra project MF1228 (From Physics to Fisheries) and DEVOTES (DEVelopment Of innovative Tools for understanding marine biodiversity and assessing good Environmental Status) funded by EU FP7 (grant agreement no. 308392), www.devotes-project.eu. GIvdM was partially supported by the Norwegian Nature Index programme. $\mathrm{HO}$ was funded was funded by the Estonian Ministry of Education and Research (grant SF0180005s10). MAT was funded by a predoctoral FPI fellowship from the Spanish Institute of Oceanography (IEO). MJJJ was supported by the EC Marie Curie IOF Grant, PIOF-GA-2013-628116. We acknowledge all those who conducted surveys to collect the data used in this study. 


\section{References}

Alexander KA, Heymans JJ, MaGill S, Tomczak MT, Holmes S, Wilding TA (In Press) Investigating the recent decline in gadoid stocks in the west of Scotland shelf ecosystem using a food-web model. ICES Journal of Marine Science

Anticamara JA, Watson R, Gelchu A, Pauly D (2011) Global fishing effort (19502010): Trends, gaps, and implications. Fisheries Research 107:131-136

Atkinson LJ, Jarre A, Shannon LJ, Field JG (2012) Evidence for Shifts in Demersal Fish Populations on the West Coast of South Africa: 1986 to 2009. In: Kruse GH, Browman HI, Cochrane KL, Evans D, Jamieson GS, Livingston PA, Woodby D, Zhang CI (eds) Global Progress in Ecosystem-Based Fisheries Management. Alaska Sea Grant, University of Alaska Fairbanks

Auber A, Travers-Trolet M, Villanueva MC, Ernande B (Submitted) Regime shift in an exploited fish community driven by natural climate oscillations. Proceedings of the National Academy of Science

Bailey N, Bailey DM, Bellini LC, Fernandes PG, Fox C, Heymans S, Holmes S, Howe J, Hughes S, Magill S, McIntyre F, McKee D, Ryan MR, Smith IP, Tyldesley G, Watret R, Turrell WR (2011) The West Coast of Scotland Marine Ecosystem: A Review of Scientific Knowledge. Marine Scotland Science Report 0911. Marine Scotland, Aberdeen

Barange M, Merino G, Blanchard JL, Scholtens J, Harle J, Allison EH, Allen JI, Holt J, Jennings $S$ (2014) Impacts of climate change on marine ecosystem production in societies dependent on fisheries. Nature Climate Change 4:211216

Barrett CB (2010) Measuring Food Insecurity. Science 327:825-828

Blanchard JL, Coll M, Trenkel VM, Vergnon R, Yemane D, Jouffre D, Link JS, Shin Y-J (2010) Trend analysis of indicators: a comparison of recent changes in the status of marine ecosystems around the world. ICES Journal of Marine Science 67:732-744

Börger T, Beaumonta NJ, Pendleton L, Boyle KJ, Cooper P, Fletcher S, Haab T, Hanemann M, Hooper TL, Hussain SS, Portela R, Stithou M, Stockill J, Taylor T, Austen MC (2014) Incorporating ecosystem services in marine planning: The role of valuation. Marine Policy 46:161-170

Bundy A, Coll M, Shannon L, Shin Y-J (2012) Global assessments of the status of marine exploited ecosystems and their management: what more is needed? Current Opinion in Environmental Sustainability (COSUST) 4:292-299

Bundy A, Shannon LJ, Rochet M-J, Neira S, Shin Y-J, Hill L, Aydin K (2010) The Good(ish), the Bad and the Ugly: a tripartite classification of ecosystem trends. ICES Journal of Marine Science 67:745-768

CBD (2010) Decision X/2: the strategic plan for biodiversity 2011-2020 and the Aichi biodiversity targets. Nagoya

Christensen V, Guenette S, Heymans JJ, Walters CJ, Watson R, Zeller D, Pauly D (2003) Hundred-year decline of North Atlantic predatory fishes. Fish and Fisheries 4:1-24

Coll M, Libralato S, Tudela S, Palomera I, Pranovi F (2008a) Ecosystem overfishing in the ocean. Plos One 3:e3881 
Coll M, Palomera I, Tudela S, Dowd M (2008b) Food-web dynamics in the South Catalan Sea ecosystem (NW Mediterranean) for 1978-2003. Ecol Model 217:95-116

Coll M, Santojanni A, Palomera I, Arneri E (2009) Food-web changes in the Adriatic Sea over the last three decades. Marine Ecology Progress Series 381:17-37

Coll M, Santojanni A, Palomera I, Arneri E (2010a) Ecosystem assessment of the North-Central Adriatic: towards a multivariate reference framework. Marine Ecology Progress Series 417:193-210

Coll M, Shannon LJ, Yemane D, Link JS, Ojaveer H, Niera S, Jouffre D, Labrosse P, Heymans JJ, Fulton EA, Shin YJ (2010b) Ranking the ecological relative status of exploited marine ecosystems. ICES Journal of Marine Science 67:769-786

Daniel TC, Muhar A, Arnberger A, Aznar 0, Boyd JW, Chan KM, Costanza R, Elmqvist T, Flint CG, Gobster PH, Gret-Regamey A, Lave R, Muhar S, Penker M, Ribe RG, Schauppenlehner T, Sikor T, Soloviy I, Spierenburg M, Taczanowska K, Tam J, von der Dunk A (2012) Contributions of cultural services to the ecosystem services agenda. Proc Natl Acad Sci U S A 109:8812-8819

Eero M (2012) Reconstructing the population dynamics of sprat (Sprattus sprattus balticus) in the Baltic Sea in the 20th century. ICES Journal of Marine Science 69:1010-1018

Eero M, MacKenzie BR, Koster FW, Gislason H (2011) Multi-decadal responses of a cod (Gadus morhua) population to human-induced trophic changes, fishing, and climate. Ecological Applications 21:214-226

EU (2004) Cod recovery plan. Council Regulation (EC) No 423/2004 of 26 February 2004 establishing measures for the recovery of the cod stocks. Official Journal of the European Union

EU Directive 2008/56/EC of the European Parliament and of the Council of 17 June 2008: Establishing a framework for community action in the field of marine environmental policy (Marine Strategy Framework Directive), http://eurlex.europa.eu/LexUriServ/LexUriServ.do?uri=0]:L:2008:164:0019:0040:EN: PDF.

European Commission (2013) Regulation (EU) No 1380/2013 of the European Parliament and of the Council of 11 December 2013 on the Common Fisheries Policy, amending Council Regulations (EC) No 1954/2003 and (EC) No 1224/2009 and repealing Council Regulations (EC) No 2371/2002 and (EC) No 639/2004 and Council Decision 2004/585/EC.

FAO (2014) The State of World Fisheries and Aquaculture 2014. In: FAO (ed). Food and Agriculture Organization of the United Nations, Rome

Foley MM, Halpern BS, Micheli F, Armsby MH, Caldwell MR, Crain CM, Prahler E, Rohr N, Sivas D, Beck MW, Carr MH, Crowder LB, Duffy JE, Hacker SD, McLeod KL, Palumbi SR, Peterson CH, Regan HM, Ruckelshaus MH, Sandifer PA, Steneck RS (2010) Guiding ecological principles for marine spatial planning. Marine Policy 34:955-966

Gabriel WL, Pearcy WG (1981) Feeding selectivity of dover sole, Microstomus pacificus, off Oregon. Fisheries Bulletin 79:749-763

Garcia SM (2009) Governance, science and society. The ecosystem approach to fisheries. In: Grafton RQ, Hilborn R, Squires D, Tait M, Williams M (eds) 
Handbook of marine fisheries conservation and management. Oxford University Press, Oxford, UK

Garcia SM, Rosenberg AA (2010) Food security and marine capture fisheries: characteristics, trends, drivers and future perspectives. Philos T Roy Soc B 365:2869-2880

Gascuel D, Coll M, Fox C, Guénette S, Guitton J, Kenny A, Knittweis L, Nielsen RJ, Piet G, Raid T, Travers-Trolet M, Shephard S (In press) Fishing impact and environmental status in European seas: a diagnosis from stock assessments and ecosystem indicators. Fish and Fisheries

Gjøsæter H, Bogstad B, Tjelmeland S (2009) Ecosystem effects of the three capelin stock collapses in the Barents Sea. Marine Biology Research 5:40-53

Guénette S, Gascuel D (2012) Shifting baselines in European fisheries: the case of the Celtic Sea and Bay of Biscay. Ocean and Coastal Management 70:10-21 Halpern BS, Longo C, Hardy D, McLeod KL, Samhouri JF, Katona SK, Kleisner K, Lester SE, O'Leary J, Ranelletti M, Rosenberg AA, Scarborough C, Selig ER, Best BD, Brumbaugh DR, Chapin FS, Crowder LB, Daly KL, Doney SC, Elfes C, Fogarty MJ, Gaines SD, Jacobsen K, Bunce-Karrer L, Leslie HM, Neeley E, Pauly D, Polasky S, Ris B, St. Martin K, Stone GS, Sumaila UR, Zeller D (2012) An index to assess the health and benefits of the global ocean. Nature 488:615620

Hjermann DØ, Bogstad B, Dingsør GE, Gjøsæter H, Ottesen G, Eikeset AM, Stenseth NC (2010) Trophic interactions affecting a key ecosystem component: a multistage analysis of the recruitment of the Barents Sea capelin (Mallotus villosus). Canadian Journal of Fisheries and Aquatic Sciences 67:1363-1375

Hunsicker ME, Ciannelli L, Bailey KM, Zador S, Stige LC (2013) Climate and demography dictate the strength of predator-prey overlap in a subarctic marine ecosystem. Plos One 8:e66025

Jackson BC, Kirby MX, Berger WH, Bjorndal KA, Botsford LW, Bourque BJ, Bradbury RH, Cooke R, Erlandson J, Estes JA, Hughes TP, Kidwell S, Lange CB, Lenihan HS, Pandolfi JM, Peterson CH, Steneck RS, Tegner MJ, Warner RR (2001) Historical overfishing and the recent collapse of coastal ecosystems. Ecology 84:162-173

Jackson JBC, Alexander K, Sala E (2011) Shifting baselines : the past and the future of ocean fisheries. Island Press, Washington, DC

Johannesen E, Ingvaldsen RB, Bogstad B, Dalpadado P, Eriksen E, Gjøsæter H, Knutsen T, Skern-Mauritzen M, Stiansen JE (2012) Changes in Barents Sea ecosystem state, 1970-2009: climate fluctuations, human impact, and trophic interactions. ICES Journal of Marine Science 69:880-889

Keller AK, Wallace JR, Horness BH, Hamel OS, Stewart IJ (2012) Variations in eastern North Pacific demersal fish biomass based on the US west coast groundfish bottom trawl survey (2003-2010). Fish B-Noaa 110:205-222

Kendall M, Gibbons JD (1990) Rank Correlation Methods. Oxford University Press, Oxford, UK

Link JS, Brodziak JKT, Edwards SF, Overholtz WJ, Mountain D, Jossi JW, Smith TD, Fogarty MJ (2002) Marine ecosystem assessment in a fisheries management context. Canadian Journal of Fisheries and Aquatic Science 59:1429-1440 
Liquete C, Piroddi C, Drakou EG, Gurney L, Katsanevakis S, Charef A, Egoh B (2013) Current Status and Future Prospects for the Assessment of Marine and Coastal Ecosystem Services: A Systematic Review. Plos One 8:e67737

Lynam CP, Cusack C, Stokes D (2010) A methodology for community-level hypothesis testing applied to detect trends in phytoplankton and fish communities in Irish waters. Estuarine, Coastal and Shelf Science 87:451-462

Möllmann C, Diekmann R, Müller-Karulis B, Kornilovs G, Plikshs M, Axe P (2009) Reorganization of a large marine ecosystem due to atmospheric and anthropogenic pressure: a discontinuous regime shift in the Central Baltic Sea. Global Change Biol 15:1377-1393

Morato T, Watson R, Pitcher TJ, Pauly D (2006) Fishing down the deep. Fish and Fisheries 7:23-33

Pauly D, Christensen V, Dalsgaard J, Froese R, Torres Jr. F (1998) Fishing down marine food webs. Science 279:860-863

Pauly D, Christensen V, Guénette S, Pitcher TJ, Sumaila UR, Walters CJ, Watson R, Zeller D (2002) Towards sustainability in world fisheries. Nature 418:689695

Pauly D, Palomares M (2010) An empirical equation to predict annual increases in fishing efficiency. Fisheries Centre Working Paper \# 2010-07, Fisheries Centre, Vancouver, B.C.

Perry RI, Cury P, Brander KM, Jennings S, Möllmann C, Planque B (2010) Sensitivity of marine systems to climate and fishing: Concepts, issues and management responses. Journal of Marine Systems 79:427-435

Piroddi C, Bearzi G, Christensen V (2010) Effects of local fisheries and ocean productivity on the northeastern Ionian Sea ecosystem. Ecol Model 221:1526-1544

Piroddi C, Teixeiraa H, Lynam C, Smith C, Alvarez M, Mazik K, Andonegi E, Churilova T, Tedesco L, Chifflet M, Chust G, Galparsoro I, Garcia AC, Kämäri M, Kryvenko O, Lassalle G, Neville S, Niquil N, Papadopoulou N, Rossberg AG, Suslin V, Uyarra M (In Review) Using ecological models to provide biodiversity indicators in support of the EU Marine Strategy Framework Directive. Ecological Indicators

R Core Team (2013) R: a language and environment for statistical computing. R Foundation for Statistical Computing, Vienna, Austria

Robinson CLK (2000) The consumption of euphausiids by the pelagic fish community off

southwestern Vancouver Island, British Columbia. Journal of Plankton Research 22:1649-1662

Rooper CN, Martin MH (2009) Predicting presence and abundance of demersal fishes: a model application to shortspine thornyhead Sebastolobus alascanus. Marine Ecology Progress Series 379:253-266

Shannon LJ, Coll M, Bundy A, Shin Y-J, Travers-Trolet M, Gascuel D, Kleisner KM, Tam J, Piroddi C, Heymans JJ, Lynam CP (2014) Trophic level-based indicators to track fishing impacts across marine ecosystems. Marine Ecology Progress Series 
Shannon LJ, Coll M, Yemane D, Jouffre D, Neira S, Betrand A, Diaz E, Shin YJ (2010) Comparing data-based indicators across upwelling and comparable systems for communicating ecosystem states and trends. ICES Journal of Marine Science 67:807-832

Shin Y-J, Bundy A, Shannon LJ, Blanchard J, Chuenpagdee R, Coll M, Knight B, Lynam C, Piet G, Rice J, Richardson AJ, Group IW (2012) Global in scope and regionally rich: an IndiSeas workshop helps shape the future of marine ecosystem indicators. Reviews in Fish Biology and Fisheries 22:621-636

Shin Y-J, Bundy A, Shannon LJ, Simier M, Coll M, Fulton EA, Link J, Jouffre D, Ojaveer H, Mackinson S, Heymans JJ, Raid T (2010a) Can simple be useful and reliable? Using ecological indicators to represent and compare the states of marine ecosystems. ICES Journal of Marine Science 67:717-731

Shin YJ, Shannon L, Bundy A, Coll M, Aydin K, Bez N, Blanchard JL, Borges MF, Diallo I, Diaz E, Heymans JJ, Hill L, Johannesen E, Jouffre D, Kifani S, Labrosse P, Link JS, Mackinson S, Masski H, Mollmann C, Niera S, Ojaveer H, Mohammed Abdallahi K, Perry I, Thiao D, Yemane D, Cury P (2010b) Using indicators for evaluating, comparing, and communicating the ecological status of exploited marine ecosystems. 2. Setting the scene. ICES Journal of Marine Science 67:692-716

Shin YJ, Shannon LJ (2010) Using indicators for evaluating, comparing and communicating the ecological status of exploited marine ecosystems. 1. The IndiSeas project. ICES Journal of Marine Science 67:686-691

Srinivasan UT, Cheung W, Watson R, Sumaila UR (2010) Food security implications of global marine catch losses due to overfishing. Journal of Bioeconomics 12:183-200

Swartz W, Sala E, Tracey S, Watson R, Pauly D (2010) The spatial expansion and ecological footprint of fisheries (1950 to present). Plos One 5:1-6

Tolimieri N, Samhouri JF, Simon V, Feist BE, Levin PS (2013) Linking the trophic fingerprint of groundfishes to ecosystem structure and function in the California Current. Ecosystems 16:1216-1229

Tomczak MT, Heymans JJ, Yletyinen J, Niiranen S, Otto SA, Blenckner T (2013) Ecological Network Indicators of Ecosystem Status and Change in the Baltic Sea. Plos One 8:e75439

Torres MA, Coll M, Heymans JJ, Christensen V, Sobrino I (2013) Food-web structure of and fishing impacts on the Gulf of Cadiz ecosystem (South-western Spain). Ecol Model 265:26-44

Wheeler B (2009) SuppDists: supplementary distributions. R package version, 1-1 Worm B, Barbier EB, Beaumont N, Duffy JE, Folke C, Halpern BS, Jackson JBC, Lotze HL, Micheli F, Palumbi SR, Sala E, Selkoe KA, Stachowicz JJ, Watson R (2006) Impacts of biodiversity loss on ocean ecosystem services. Science 314:787790

Worm B, Hilborn R, Baum JK, Branch TA, Collie JS, Costello C, Fogarty MJ, Fulton EA, Hutchings JA, Jennings S, Jensen OP, Lotze HK, Mace PM, McClanahan TR, Minto C, Palumbi SR, Parma AM, Ricard D, Rosenberg AA, Watson R, Zeller D (2009) Rebuilding Global Fisheries. Science 325:578-585 
Zador S, Aydin C, Cope JM (2011) Fine-scale analysis of arrowtooth flounder Atherestes stomias catch rates reveals spatial trends in abundance. Marine Ecology Progress Series 438:229-239 


\section{Tables}

Table 1. Description of ecosystems used in the Non-declining Exploited Species (NDES) analysis, including the number of exploited species biomass trends and average length of the time series used to calculate the NDES in each ecosystem. Additionally, the significance of Kendall's tau statistic as determined by a two-sided $p$-value (bolded if significant), and proportion of non-declining species derived from the NDES indicator are provided. A significant Kendall's tau indicates more declining or increasing trends than could be expected by chance.

\begin{tabular}{|c|c|c|c|c|c|c|}
\hline Ecosystem & Geographic area & Type of ecosystem & $\begin{array}{l}\text { Number } \\
\text { of } \\
\text { biomass } \\
\text { trends }\end{array}$ & $\begin{array}{l}\text { Average } \\
\text { time } \\
\text { series } \\
\text { length } \\
\end{array}$ & $\begin{array}{l}\text { Two-sided } \\
\text { p -value of } \\
\text { Kendall's } \\
\text { tau }\end{array}$ & $\begin{array}{l}\text { Proportion of } \\
\text { non-declining } \\
\text { species } \\
\text { (NDES) }\end{array}$ \\
\hline Barents Sea & NE Atlantic & High latitude & 11 & 33 & 0.006 & 0.82 \\
\hline Bay of Biscay & NE Atlantic & Temperate & 9 & 23 & 0.009 & 0.22 \\
\hline Central Baltic Sea & NE Atlantic & Brackish temperate & 6 & 25 & 0.441 & 0.50 \\
\hline Eastern Bering Sea & NE Pacific & High latitude & 22 & 29 & 0.003 & 0.59 \\
\hline Eastern Scotian Shelf & NW Atlantic & Temperate & 30 & 41 & $<0.001$ & 0.37 \\
\hline English Channel & NE Atlantic & Temperate & 31 & 23 & 0.001 & 0.55 \\
\hline Guinean Shelf & East-central Atlantic & Upwelling & 20 & 25 & $<0.001$ & 0.00 \\
\hline Gulf of Cadiz & NE Atlantic & Temperate & 13 & 18 & $<0.001$ & 0.08 \\
\hline Irish Sea & NE Atlantic & Temperate & 15 & 18 & 0.009 & 0.40 \\
\hline North Aegean Sea & NE Mediterranean & Temperate & 57 & 4 & $<0.001$ & 0.44 \\
\hline North Ionian Sea & NE Mediterranean & Temperate & 5 & 45 & 0.013 & 0.00 \\
\hline North Sea & NE Atlantic & Temperate & 30 & 28 & $<0.001$ & 0.73 \\
\hline North-central Adriatic & Central Mediterranean & Temperate & 17 & 25 & $<0.001$ & 0.29 \\
\hline Northeast U.S. & NW Atlantic & Temperate & 122 & 47 & $<0.001$ & 0.75 \\
\hline Northern Humboldt Current & SE Pacific & Upwelling & 10 & 19 & 0.055 & 0.40 \\
\hline Portuguese coast & NE Atlantic & Upwelling & 10 & 26 & 0.003 & 0.80 \\
\hline Scottish west coast & NE Atlantic & Temperate & 11 & 24 & 0.076 & 0.45 \\
\hline South Catalan Sea & NW Mediterranean & Temperate & 16 & 34 & 0.037 & 0.56 \\
\hline Southern Benguela & SE Atlantic & Upwelling & 59 & 29 & $<0.001$ & 0.59 \\
\hline U.S. west coast & NE Pacific & Temperate & 29 & 8 & $<0.001$ & 0.41 \\
\hline Vancouver Island & NE Pacific & Temperate & 22 & 31 & $<0.001$ & 0.77 \\
\hline Western Scotian Shelf & NW Atlantic & Temperate & 30 & 41 & $<0.001$ & 0.60 \\
\hline
\end{tabular}


Table 2. Correlation over time between the biomass time series of each exploited species and the three community indicators (proportion of predatory fish-PPF, and the average trophic level of the surveyed community-TLsc, and mean life span-mLS) for each ecosystem. The proportions of correlations greater than 0.5 are termed 'positively correlated' and proportions less than 0.5 are termed 'negatively correlated', referring to the preponderance of species-level biomass trends that are positively or negatively correlated with the particular community indicator. The proportions are bolded if the Kendall's tau is significant (i.e., based on the $p$-values).

\begin{tabular}{|c|c|c|c|c|c|c|}
\hline \multirow[t]{2}{*}{ Ecosystem } & \multicolumn{2}{|c|}{ Proportion predatory fish (PPF) } & \multicolumn{2}{|c|}{ Survey trophic level (TLsc) } & \multicolumn{2}{|c|}{ Mean life span (mLS) } \\
\hline & $\begin{array}{l}\text { Two-sided p - } \\
\text { value of } \\
\text { Kendall's tau }\end{array}$ & $\begin{array}{l}\text { Proportion } \\
\text { positively } \\
\text { correlated } \\
\text { trends } \\
\end{array}$ & $\begin{array}{l}\text { Two-sided p } \\
\text {-value of } \\
\text { Kendall's tau }\end{array}$ & $\begin{array}{l}\text { Proportion } \\
\text { positively } \\
\text { correlated } \\
\text { trends } \\
\end{array}$ & $\begin{array}{l}\text { Two-sided p - } \\
\text { value of } \\
\text { Kendall's tau }\end{array}$ & $\begin{array}{l}\text { Proportion } \\
\text { positively } \\
\text { correlated } \\
\text { trends } \\
\end{array}$ \\
\hline Barents Sea & 0.023 & 0.73 & 0.076 & 0.45 & 0.076 & 0.55 \\
\hline Bay of Biscay & 0.037 & 0.33 & 0.037 & 0.78 & -- & -- \\
\hline Central Baltic Sea & 0.441 & 0.50 & -- & -- & 0.441 & 0.50 \\
\hline Eastern Bering Sea & 0.001 & 0.64 & $<0.001$ & 0.27 & $<0.001$ & 0.27 \\
\hline Eastern Scotian Shelf & $<0.001$ & 0.70 & $<0.001$ & 0.67 & $<0.001$ & 0.63 \\
\hline English Channel & $<0.001$ & 0.61 & $<0.001$ & 0.74 & $<0.001$ & 0.61 \\
\hline Guinean Shelf & $<0.001$ & 0.05 & $<0.001$ & 0.90 & $<0.001$ & 0.95 \\
\hline Gulf of Cadiz & 0.015 & 0.62 & 0.015 & 0.38 & $<0.001$ & 0.85 \\
\hline Irish Sea & 0.028 & 0.67 & 0.028 & 0.53 & 0.028 & 0.47 \\
\hline North Aegean Sea & $<0.001$ & 0.51 & $<0.001$ & 0.49 & $<0.001$ & 0.32 \\
\hline Northern Humboldt Current & 0.015 & 0.70 & 0.055 & 0.60 & 0.015 & 0.70 \\
\hline North Ionian Sea & 0.013 & 1.00 & 0.013 & 0.00 & 0.013 & 1.00 \\
\hline North-central Adriatic & 0.046 & 0.53 & 0.046 & 0.53 & $<0.001$ & 0.29 \\
\hline Northeast U.S. & $<0.001$ & 0.25 & $<0.001$ & 0.34 & $<0.001$ & 0.60 \\
\hline North Sea & $<0.001$ & 0.57 & $<0.001$ & 0.40 & $<0.001$ & 0.40 \\
\hline Portuguese coast & 0.055 & 0.70 & 0.055 & 0.40 & 0.055 & 0.60 \\
\hline Southern Benguela & $<0.001$ & 0.61 & $<0.001$ & 0.46 & $<0.001$ & 0.59 \\
\hline South Catalan Sea & 0.013 & 0.56 & 0.013 & 0.56 & 0.004 & 0.63 \\
\hline Scottish west coast & 0.023 & 0.36 & 0.076 & 0.64 & 0.023 & 0.36 \\
\hline U.S. west coast & 0.001 & 0.48 & $<0.001$ & 0.59 & $<0.001$ & 0.28 \\
\hline Vancouver Island & 0.001 & 0.64 & 0.003 & 0.55 & 0.008 & 0.50 \\
\hline Western Scotian Shelf & $<0.001$ & 0.53 & $<0.001$ & 0.47 & $<0.001$ & 0.40 \\
\hline
\end{tabular}


Figures
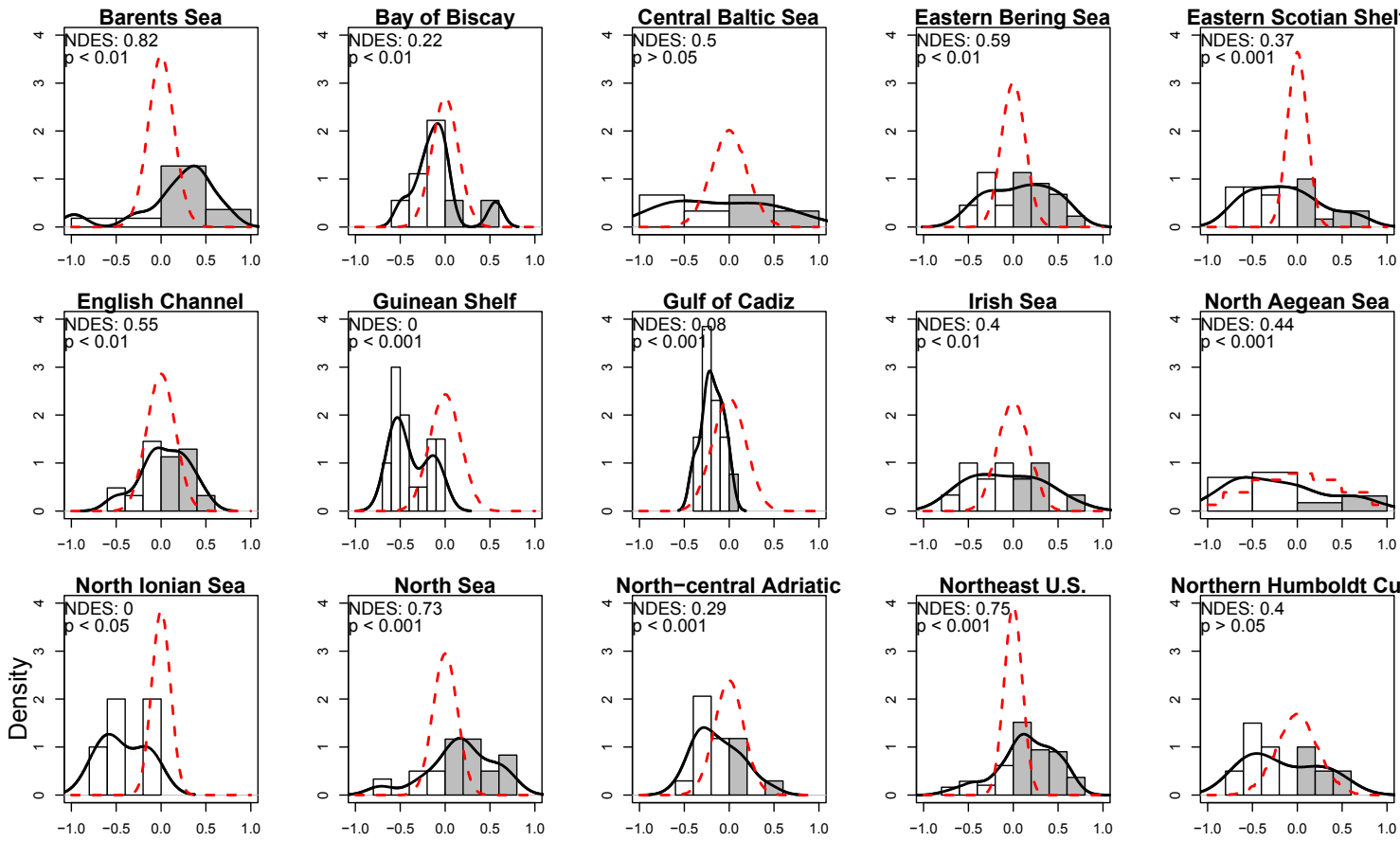

North-central Adriatic
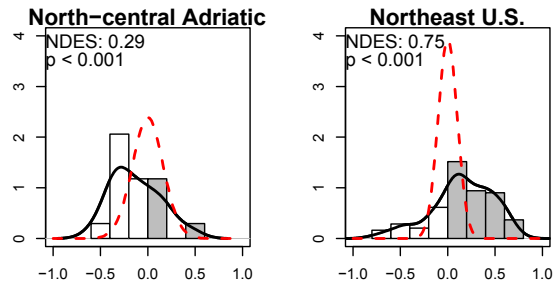
$\underset{\forall-N D E S: 0.4}{\text { Northern Humboldt Curr. }}$
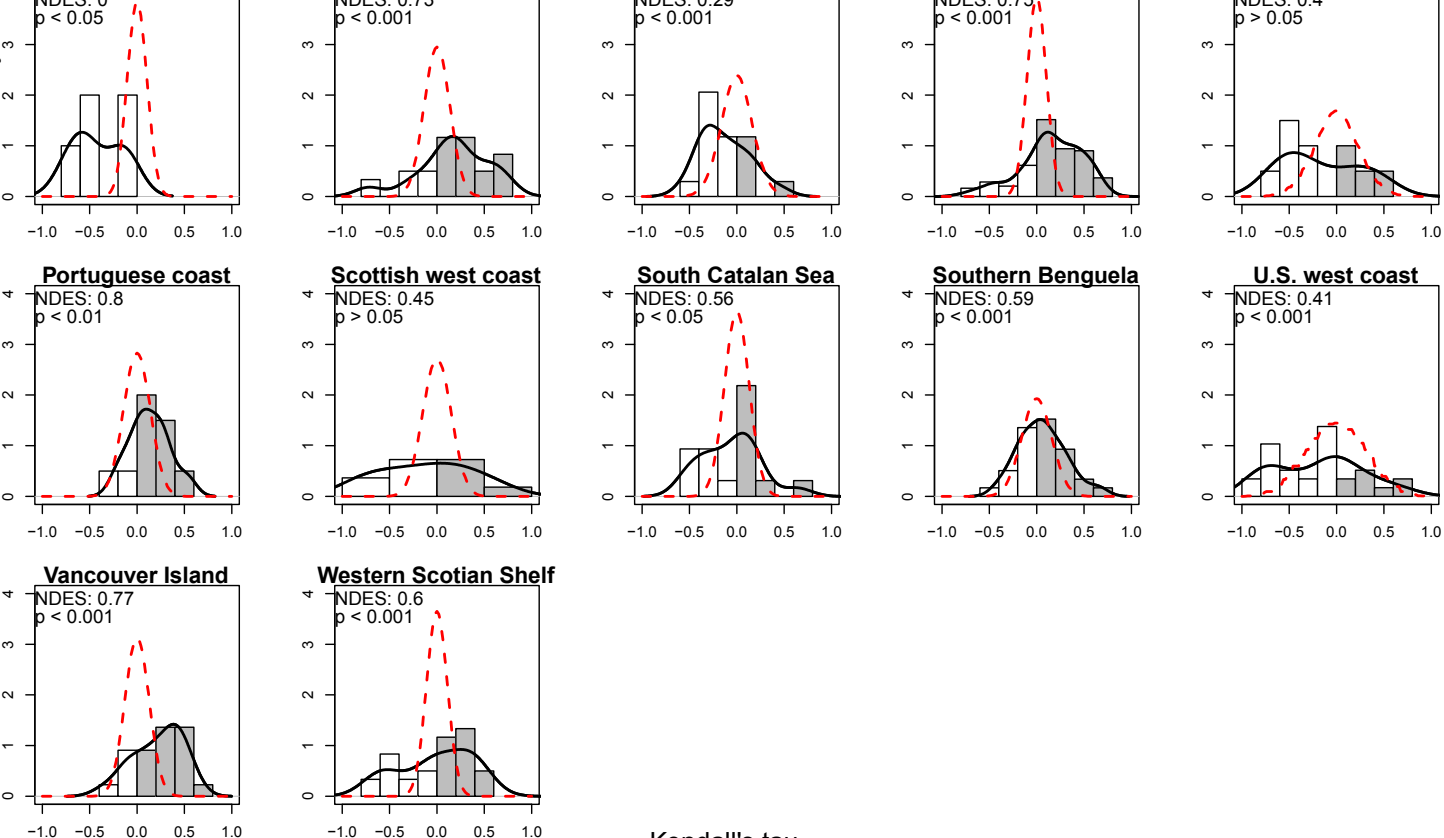

Kendall's tau

Figure 1. True histograms (bars) of Kendall rank coefficients (tau) by ecosystem with Kernel density smooth functions (solid black lines) contrasted with the theoretical expected distribution of tau by ecosystem (red dashed lines). Shifts in the solid line to the left or right of the dashed line, or histogram bars to the left or right of zero that are taller than the red line, indicate more temporal decreases or increases in the biomass of exploited fish species in the community than would be expected by chance (two-tailed p-value categories are listed in the top left corner of each graph). The white area in the histograms (negative correlations, Kendall's tau < 0) illustrated the proportion of declining exploited species and the grey area in the histograms (positive correlations, Kendall's tau $>0$ ) illustrates the proportion of non-declining exploited species in each ecosystem. The number of non-declining exploited species out of the total is the indicator we call the 'Non-declining Exploited Species' indicator (NDES). NDES values are listed in the top left corner of the graphs with the associated significance level of the indicator (twotailed $p$-value categories) for each ecosystem. 


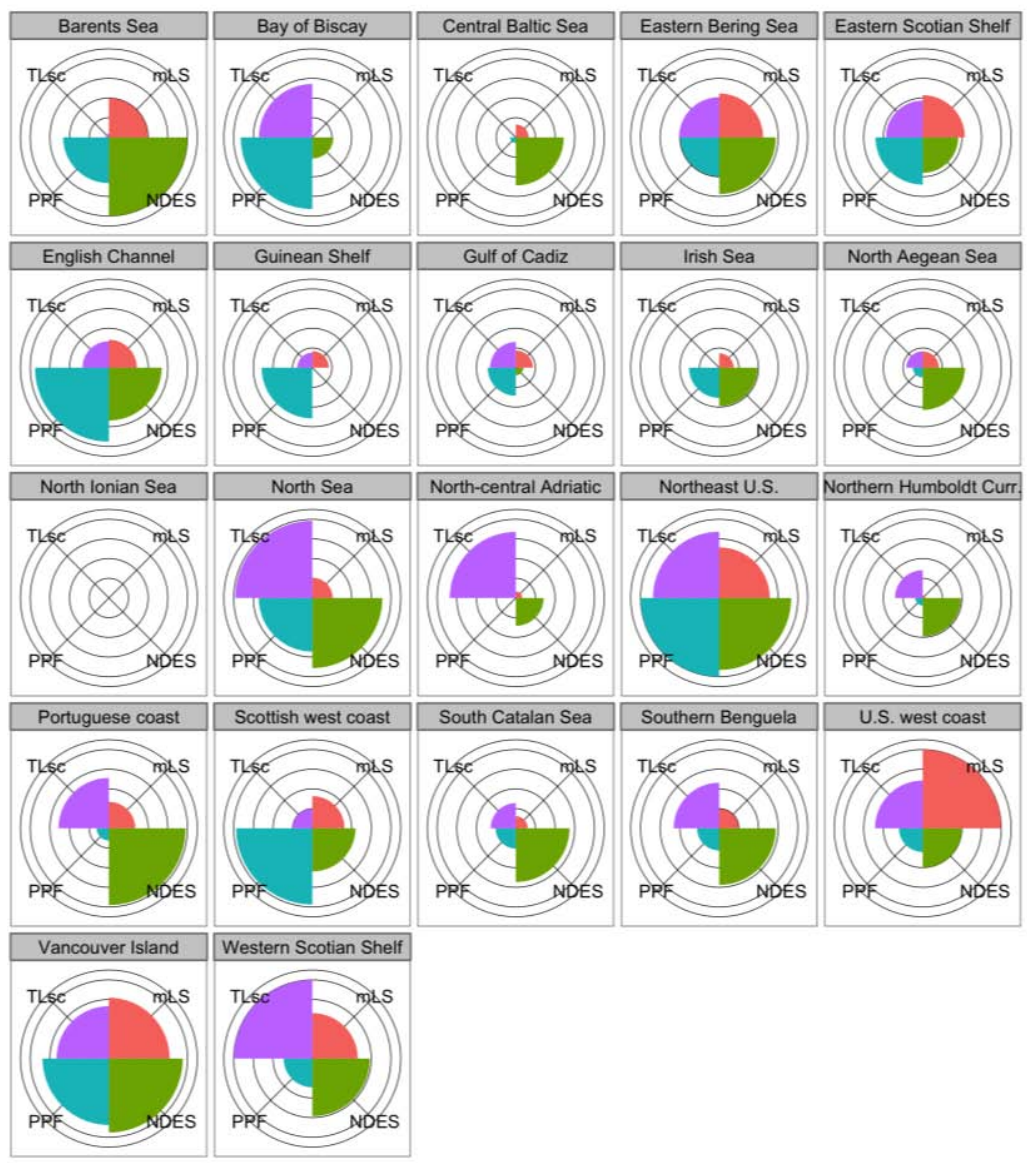

Figure 2. Petal plot of current state for each of the NDES indicator and the three community indicators (mean life span-mLS, proportion of predatory fish-PPF, and the average trophic level of the surveyed community-TLsc) for each ecosystem. Each indicator is scaled from zero to one, with a score of one indicating a 'better' status. A larger petal corresponds to a higher score. Note that the blank plot for the north Ionian Sea ecosystem reflects the fact that all indicator scores were the lowest in comparison to the other ecosystems. 


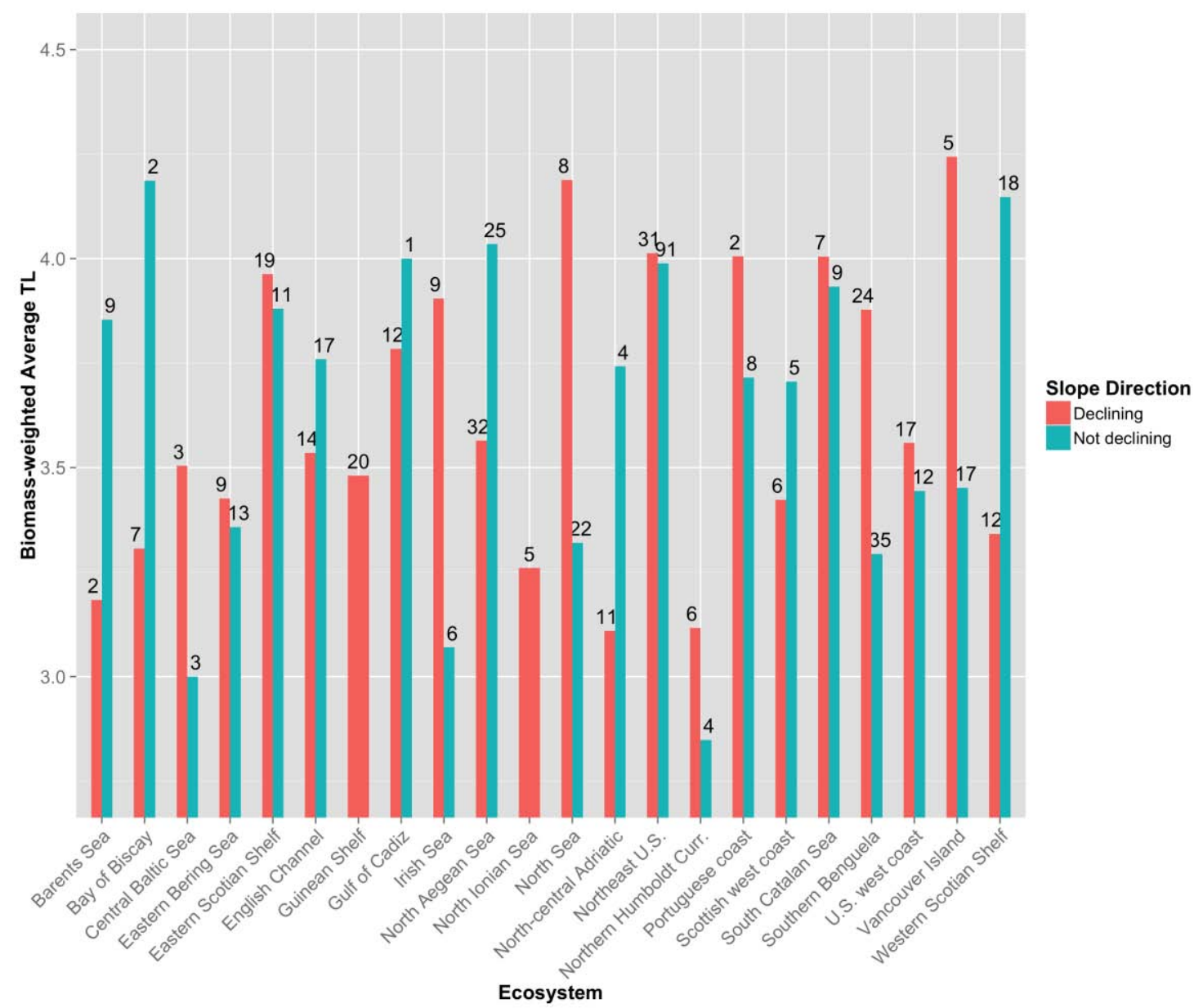

Figure 3. Biomass-weighted average trophic levels of the exploited species trends that are declining (red) and not declining (blue) for each ecosystem. Numbers on the top of each bar correspond to the number of biomass trends of exploited species for each category and ecosystem. Note that the $y$-axis has a lower truncation at 2.75 . 

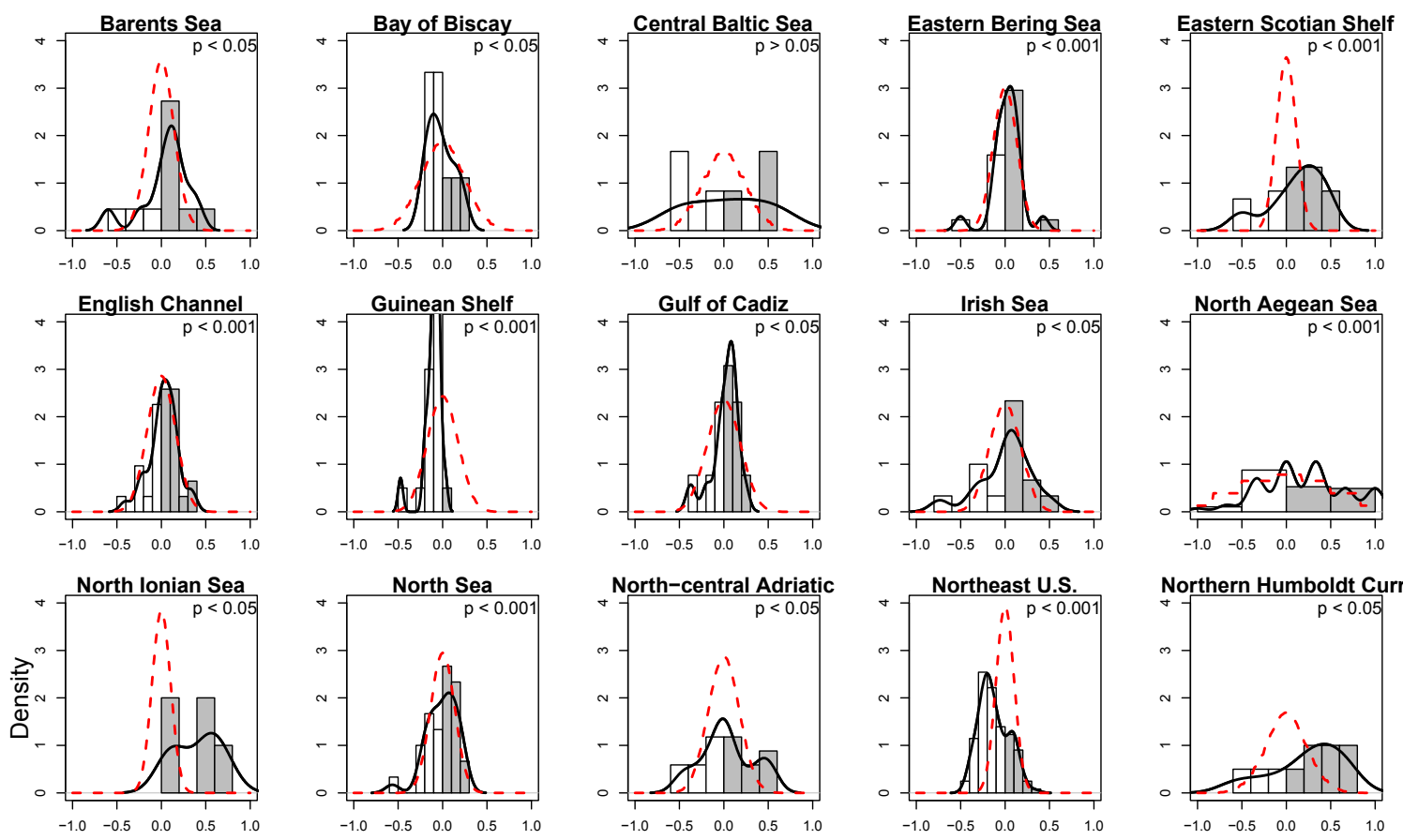

Northern Humboldt Curr.
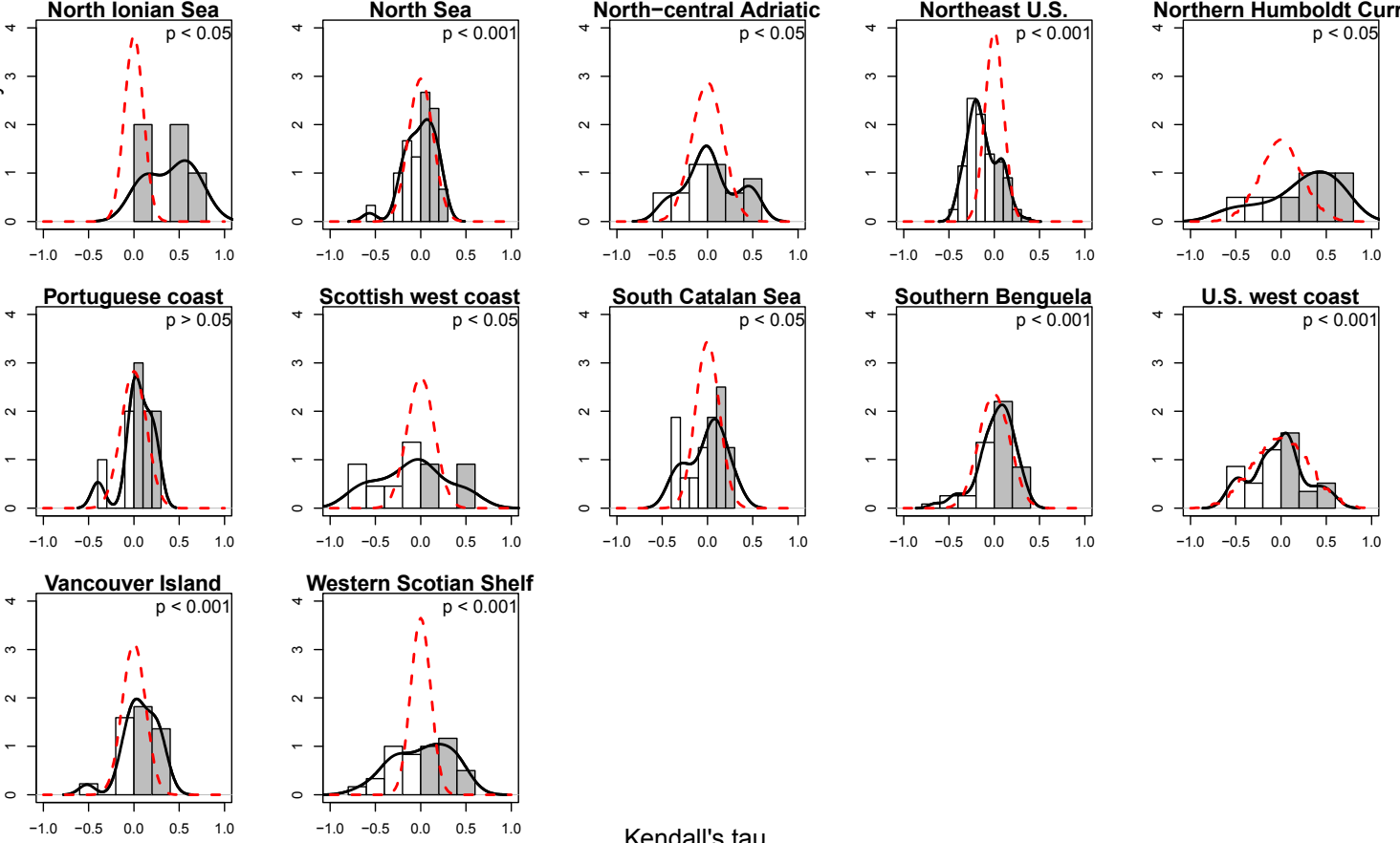

Kendall's tau

Figure 4. True histograms (bars) of Kendall rank coefficients (tau) by ecosystem indicating the correlation of the exploited species biomass time series with the trend in the community indicator, proportion of predatory fish (PPF), over the whole time series in which both indicators are available. Kernel density smooth functions (solid black lines) are contrasted with the theoretical expected distribution of tau by ecosystem (red dashed lines). A shift in the solid line to the left or right of the dashed line, or histogram bars to the left or right of zero that are taller than the red line, indicates more negative (non-shaded area of histogram) or positive (grey shaded area of histogram) correlations between the PPF and the trends in the exploited species biomass in the community than would be expected by chance (two tailed p-values are listed above each graph). 

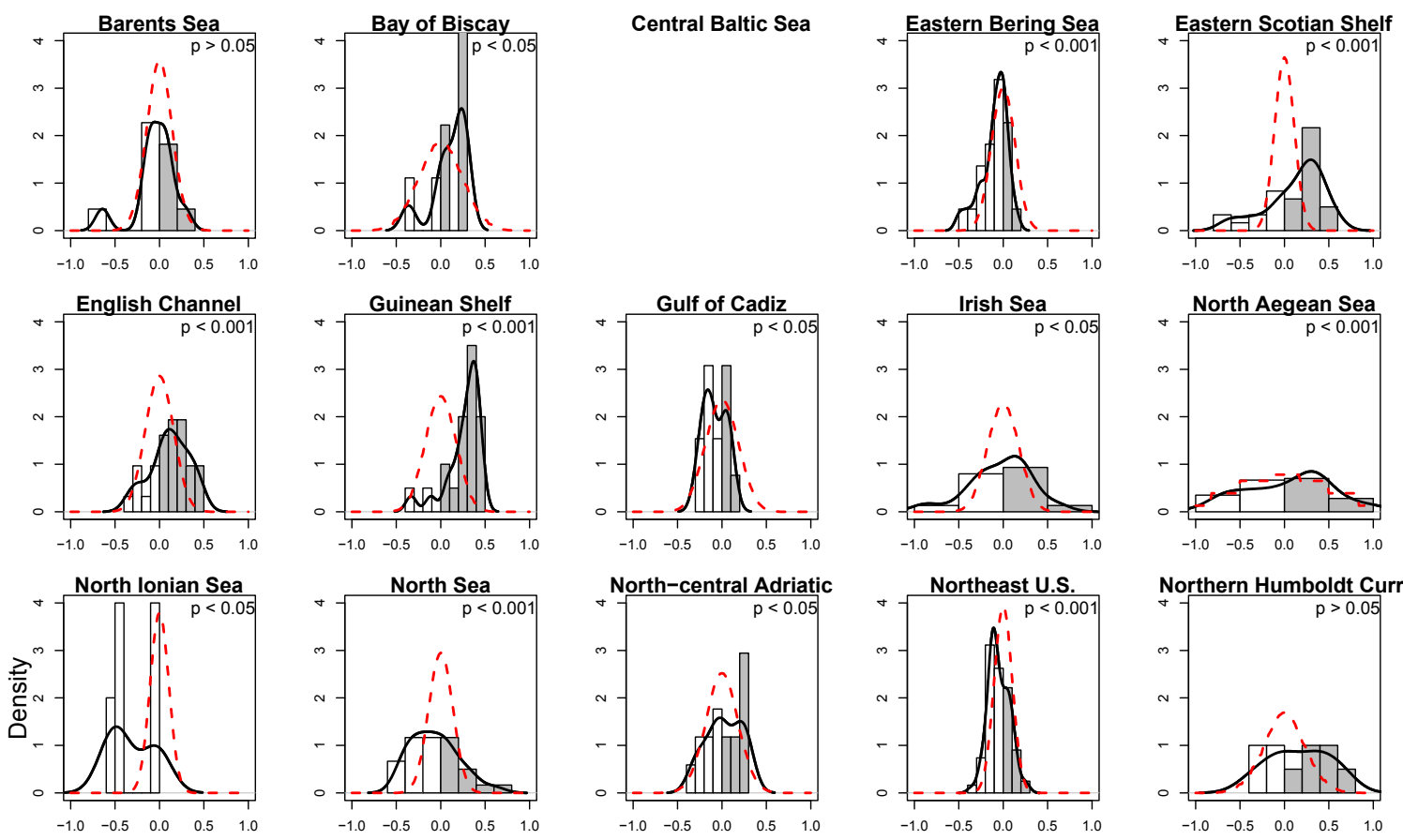

Northern Humboldt Curr
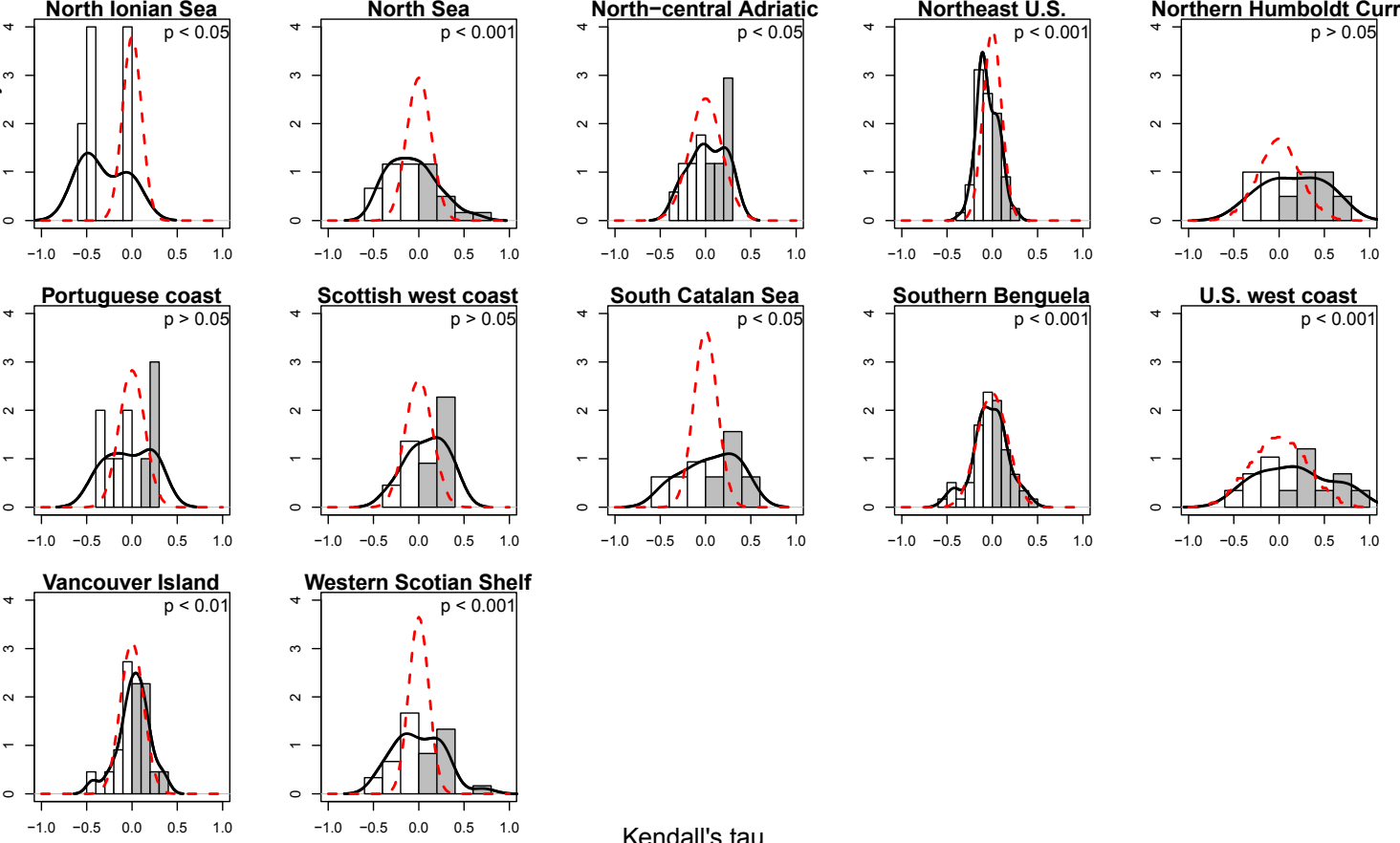

Kendall's tau

Figure 5. True histograms (bars) of Kendall rank coefficients (tau) by ecosystem indicating the correlation of the exploited species biomass time series with the trend in the community indicator, average trophic level of the surveyed community (TLSc), over the whole time series in which both indicators are available. Kernel density smooth functions (solid black lines) are contrasted with the theoretical expected distribution of tau by ecosystem (red dashed lines). A shift in the solid line to the left or right of the dashed line, or histogram bars to the left or right of zero that are taller than the red line, indicates more negative (non-shaded area of histogram) or positive (grey shaded area of histogram) correlations between the TLsc and the trends in the exploited species biomass in the community than would be expected by chance (two tailed pvalues are listed above each graph). The TLsc indicator was not available for the central Baltic Sea ecosystem. 

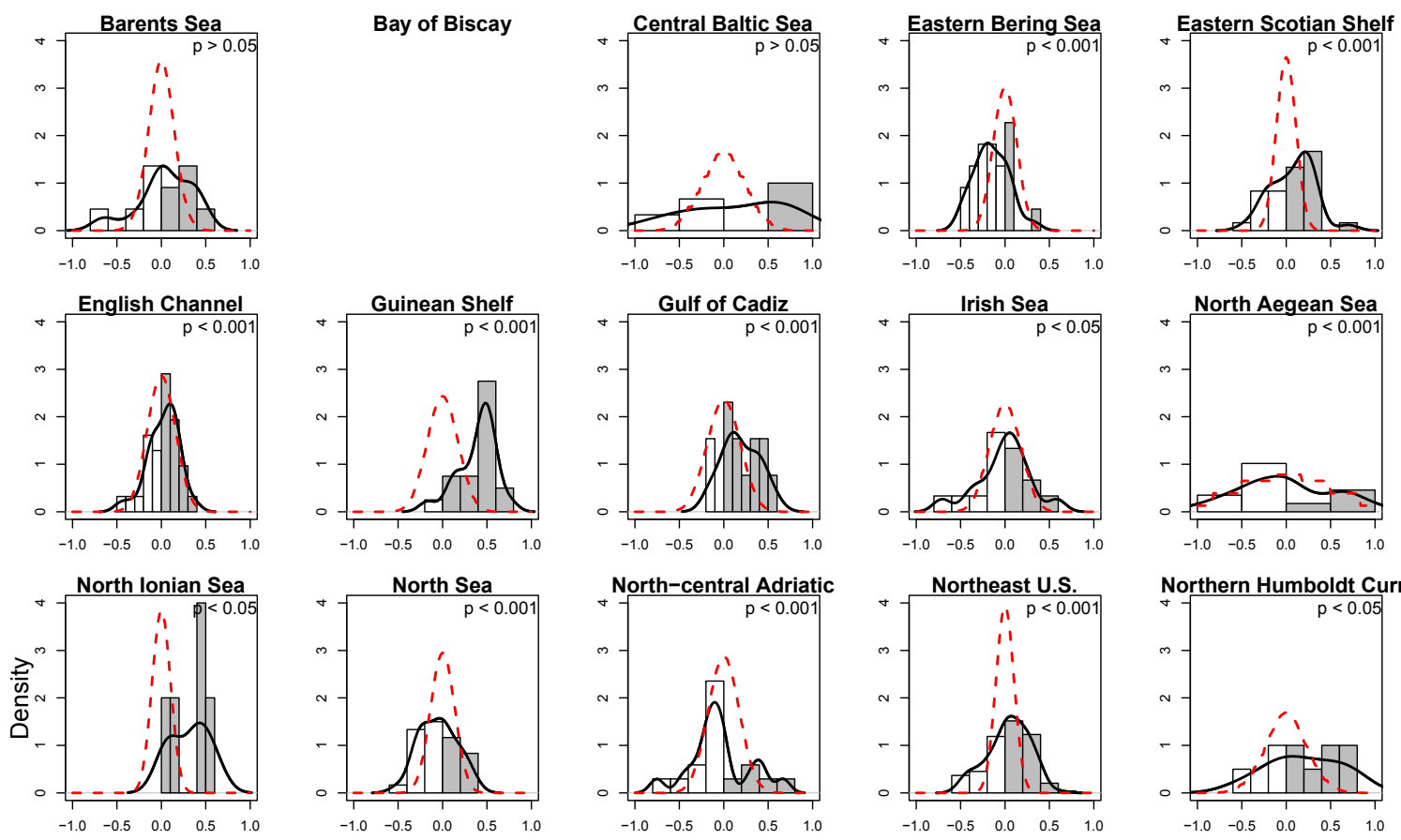

Northern Humboldt Curr.
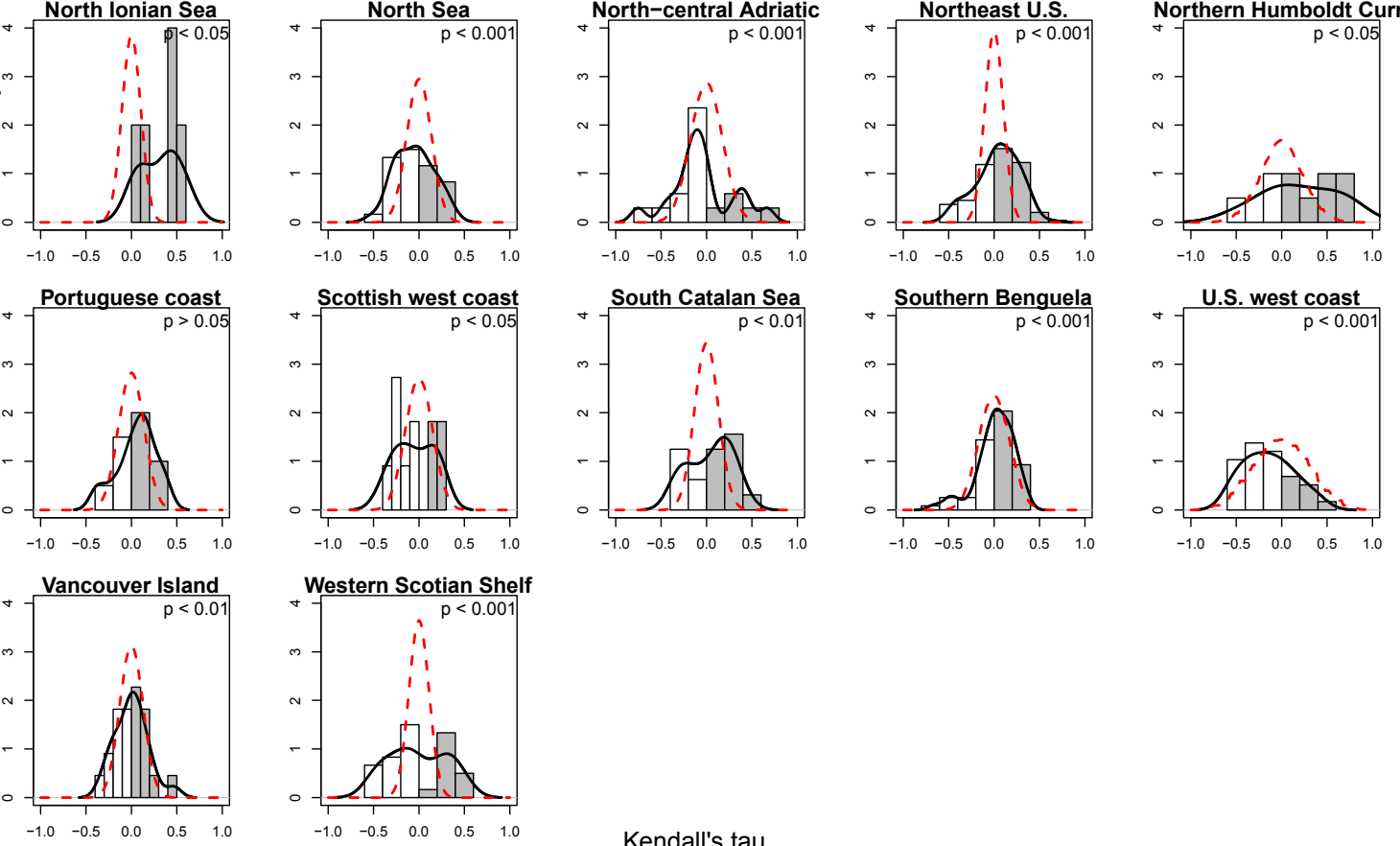

Kendall's tau

Figure 6. True histograms (bars) of Kendall rank coefficients (tau) by ecosystem indicating the correlation of the exploited species biomass time series with the trend in the community indicator, mean life span ( $\mathrm{mLS}$ ), over the whole time series in which both indicators are available. Kernel density smooth functions (solid black lines) are contrasted with the theoretical expected distribution of tau by ecosystem (red dashed lines). A shift in the solid line to the left or right of the dashed line, or histogram bars to the left or right of zero that are taller than the red line, indicates more negative (non-shaded area of histogram) or positive (grey shaded area of histogram) correlations between the $\mathrm{mLS}$ and the trends in the exploited species biomass in the community than would be expected by chance (two tailed $p$-values are listed above each graph). The $\mathrm{mLS}$ indicator was not available for the Bay of Biscay ecosystem. 

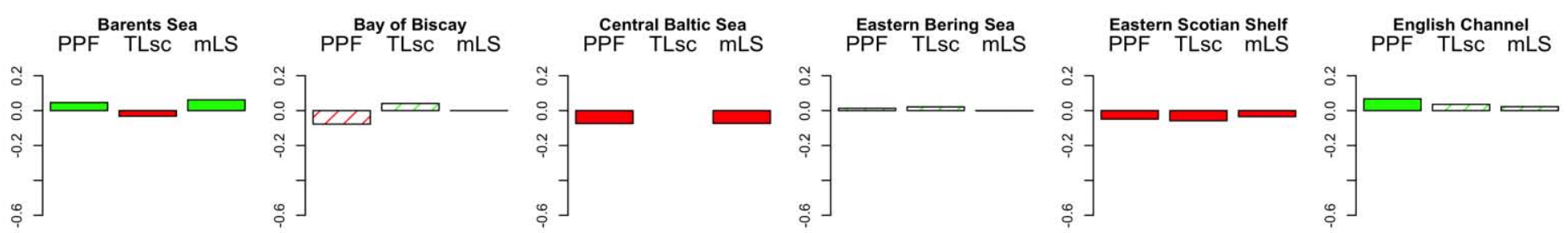

Guinean Shelf

Gulf of Cadiz

Irish Sea

North Aegean Sea

North lonian Sea

North Sea
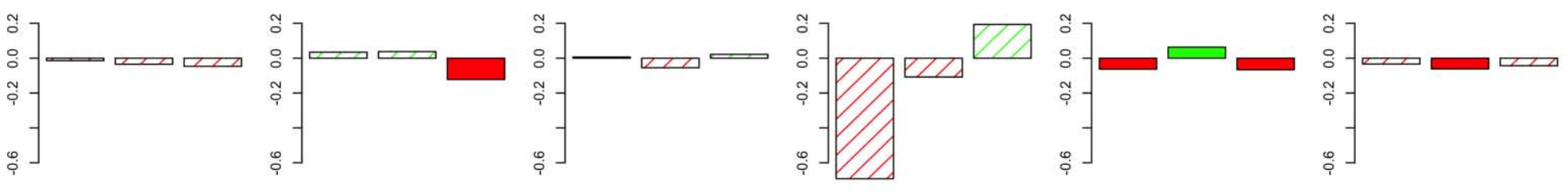

North-central Adriatic

Northeast U.S.

Northern Humboldt Curr.

Portuguese coast

Scottish west coast

South Catalan Sea
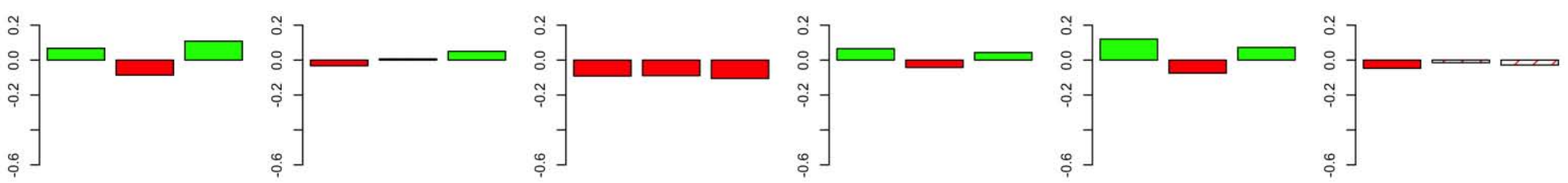

Southern Benguela

U.S. west coast

Vancouver Island

Western Scotian Shelf

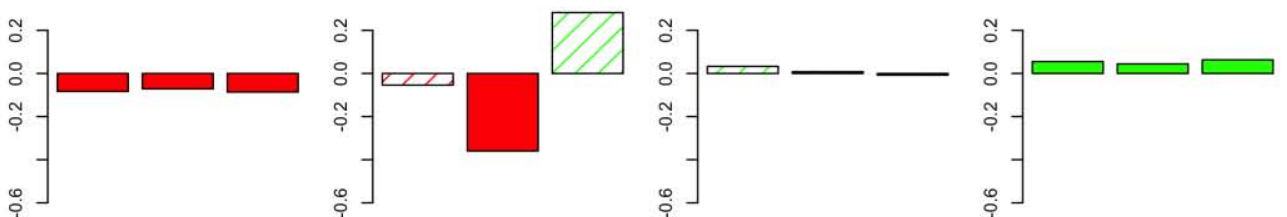

Figure 7. Histograms of slopes of the three independent indicators, proportion of predatory fish (PPF), trophic level of the surveyed community (TLsc), and mean life span $(\mathrm{mLS})$. Solid red indicates a significant decreasing slope and green indicates a significant increasing slope. Striped lines indicate a non-significant trend. These slopes were calculated from standardized time-series using generalized least-squares with autoregressive errors. 


\section{Supplementary Information}

Table S1. Species time series assessed for each ecosystem, with the length of the time series, the trophic level of the species (from www.fishbase.org or local estimates from ecosystem experts), the Kendall's tau correlation coefficient of the biomass with years, and the relative proportion that each species' average biomass contributes to the overall average exploited biomass available for a given Ecosystem. A negative or positive correlation indicates that the biomass is decreasing or increasing, respectively. An asterisk (*) indicates a proportional contribution to total exploited biomass less than 0.0001 .

\begin{tabular}{|c|c|c|c|c|c|c|}
\hline Ecosystem & Scientific name & Common name & $\begin{array}{l}\text { Length } \\
\text { of time } \\
\text { series }\end{array}$ & $\begin{array}{l}\text { Trophic } \\
\text { level }\end{array}$ & Correlation & $\begin{array}{l}\text { Proportional } \\
\text { contribution } \\
\text { to total } \\
\text { exploited } \\
\text { biomass }\end{array}$ \\
\hline $\begin{array}{l}\text { Barents } \\
\text { Sea }\end{array}$ & Boreogadus saida & Polar cod & 25 & 3.10 & 0.5800 & 0.0941 \\
\hline $\begin{array}{l}\text { Barents } \\
\text { Sea }\end{array}$ & Clupea harengus & Atlantic herring & 38 & 3.23 & 0.4264 & 0.1122 \\
\hline $\begin{array}{l}\text { Barents } \\
\text { Sea }\end{array}$ & Gadus morhua & Atlantic cod & 38 & 4.42 & 0.1750 & 0.1730 \\
\hline $\begin{array}{l}\text { Barents } \\
\text { Sea }\end{array}$ & Mallotus villosus & Capelin & 38 & 3.15 & -0.2774 & 0.3394 \\
\hline $\begin{array}{l}\text { Barents } \\
\text { Sea }\end{array}$ & $\begin{array}{l}\text { Melanogrammus } \\
\text { aeglefinus }\end{array}$ & Haddock & 38 & 4.09 & 0.4054 & 0.0459 \\
\hline $\begin{array}{l}\text { Barents } \\
\text { Sea }\end{array}$ & $\begin{array}{l}\text { Micromesistius } \\
\text { poutassous }\end{array}$ & Blue whiting & 27 & 4.01 & 0.3333 & 0.0420 \\
\hline $\begin{array}{l}\text { Barents } \\
\text { Sea }\end{array}$ & Pandalus borealis & Northern prawn & 38 & 2.46 & 0.0128 & 0.0002 \\
\hline $\begin{array}{l}\text { Barents } \\
\text { Sea }\end{array}$ & Pollachius virens & Saithe & 38 & 4.38 & 0.3826 & 0.0716 \\
\hline $\begin{array}{l}\text { Barents } \\
\text { Sea }\end{array}$ & $\begin{array}{l}\text { Reinhardtius } \\
\text { hippoglossoides }\end{array}$ & Greenland halibut & 38 & 4.48 & 0.1465 & 0.0129 \\
\hline $\begin{array}{l}\text { Barents } \\
\text { Sea }\end{array}$ & Sebastes marinus & Ocean perch & 25 & 4.08 & -0.9699 & 0.0126 \\
\hline $\begin{array}{l}\text { Barents } \\
\text { Sea }\end{array}$ & Sebastes mentella & Beaked redfish & 19 & 3.65 & 0.7310 & 0.0961 \\
\hline $\begin{array}{l}\text { Bay of } \\
\text { Biscay }\end{array}$ & $\begin{array}{l}\text { Engraulis } \\
\text { encrasicolus }\end{array}$ & European anchovy & 24 & 3.11 & -0.1159 & 0.0918 \\
\hline $\begin{array}{l}\text { Bay of } \\
\text { Biscay }\end{array}$ & $\begin{array}{l}\text { Lepidorhombus } \\
\text { whiffiagonis }\end{array}$ & Megrim & 22 & 3.58 & 0.0130 & 0.0146 \\
\hline $\begin{array}{l}\text { Bay of } \\
\text { Biscay }\end{array}$ & Lophius budegassa & Black-bellied angler & 22 & 4.48 & -0.0211 & 0.0151 \\
\hline $\begin{array}{l}\text { Bay of } \\
\text { Biscay }\end{array}$ & Lophius piscatorius & Angler & 21 & 4.49 & 0.5619 & 0.0291 \\
\hline $\begin{array}{l}\text { Bay of } \\
\text { Biscay }\end{array}$ & $\begin{array}{l}\text { Merluccius } \\
\text { merluccius }\end{array}$ & European hake & 33 & 4.42 & -0.3068 & 0.0445 \\
\hline $\begin{array}{l}\text { Bay of } \\
\text { Biscay }\end{array}$ & $\begin{array}{l}\text { Nephrops } \\
\text { norvegicus }\end{array}$ & Norway lobster & 23 & 2.88 & -0.1621 & 0.0250 \\
\hline $\begin{array}{l}\text { Bay of } \\
\text { Biscay }\end{array}$ & Scomber scombrus & Atlantic mackerel & 29 & 3.18 & -0.0542 & 0.6107 \\
\hline $\begin{array}{l}\text { Bay of } \\
\text { Biscay }\end{array}$ & Solea solea & Common sole & 27 & 3.17 & -0.4815 & 0.0378 \\
\hline
\end{tabular}




\begin{tabular}{|c|c|c|c|c|c|c|}
\hline $\begin{array}{l}\text { Bay of } \\
\text { Biscay }\end{array}$ & $\begin{array}{l}\text { Trachurus } \\
\text { trachurus }\end{array}$ & $\begin{array}{l}\text { Atlantic horse } \\
\text { mackerel }\end{array}$ & 39 & 3.64 & -0.2173 & 0.1314 \\
\hline $\begin{array}{l}\text { Central } \\
\text { Baltic Sea }\end{array}$ & Clupea harengus & Atlantic herring & 37 & 3.23 & -0.7658 & 0.4445 \\
\hline $\begin{array}{l}\text { Central } \\
\text { Baltic Sea }\end{array}$ & Gadus morhua & Atlantic cod & 37 & 4.42 & -0.5646 & 0.1331 \\
\hline $\begin{array}{l}\text { Central } \\
\text { Baltic Sea }\end{array}$ & Platichthys flesus & European flounder & 13 & 3.53 & -0.4000 & 0.0001 \\
\hline $\begin{array}{l}\text { Central } \\
\text { Baltic Sea }\end{array}$ & $\begin{array}{l}\text { Pleuronectes } \\
\text { platessa }\end{array}$ & European plaice & 13 & 3.26 & 0.7179 & $*$ \\
\hline $\begin{array}{l}\text { Central } \\
\text { Baltic Sea }\end{array}$ & Psetta maxima & Turbot & 13 & 3.05 & 0.1961 & $*$ \\
\hline $\begin{array}{l}\text { Central } \\
\text { Baltic Sea }\end{array}$ & Sprattus sprattus & European sprat & 37 & 3.00 & 0.2793 & 0.4223 \\
\hline $\begin{array}{l}\text { Eastern } \\
\text { Bering Sea }\end{array}$ & $\begin{array}{l}\text { Anoplopoma } \\
\text { fimbria }\end{array}$ & Sablefish & 29 & 3.83 & -0.3022 & 0.0056 \\
\hline $\begin{array}{l}\text { Eastern } \\
\text { Bering Sea }\end{array}$ & $\begin{array}{l}\text { Atheresthes } \\
\text { evermanni }\end{array}$ & Kamchatka flounder & 29 & 4.45 & 0.5598 & 0.0010 \\
\hline $\begin{array}{l}\text { Eastern } \\
\text { Bering Sea }\end{array}$ & $\begin{array}{l}\text { Atheresthes } \\
\text { stomias }\end{array}$ & $\begin{array}{l}\text { Arrowtooth } \\
\text { flounder }\end{array}$ & 29 & 4.26 & 0.6158 & 0.0268 \\
\hline $\begin{array}{l}\text { Eastern } \\
\text { Bering Sea }\end{array}$ & $\begin{array}{l}\text { Chionoecetes } \\
\text { opilio }\end{array}$ & Snow crab & 29 & 2.30 & -0.2315 & 0.0239 \\
\hline $\begin{array}{l}\text { Eastern } \\
\text { Bering Sea }\end{array}$ & $\begin{array}{l}\text { Chionoecetes } \\
\text { bairdi }\end{array}$ & Tanner crab & 29 & 2.30 & -0.0148 & 0.0047 \\
\hline $\begin{array}{l}\text { Eastern } \\
\text { Bering Sea }\end{array}$ & Clupea pallasii & Pacific herring & 29 & 3.15 & 0.1429 & 0.0208 \\
\hline $\begin{array}{l}\text { Eastern } \\
\text { Bering Sea }\end{array}$ & $\begin{array}{l}\text { Enteroctopus } \\
\text { dofleini }\end{array}$ & $\begin{array}{l}\text { North Pacific giant } \\
\text { octopus }\end{array}$ & 29 & 3.33 & -0.2611 & 0.0023 \\
\hline $\begin{array}{l}\text { Eastern } \\
\text { Bering Sea }\end{array}$ & $\begin{array}{l}\text { Gadus } \\
\text { macrocephalus }\end{array}$ & Pacific cod & 29 & 4.01 & -0.5025 & 0.0830 \\
\hline $\begin{array}{l}\text { Eastern } \\
\text { Bering Sea }\end{array}$ & $\begin{array}{l}\text { Glyptocephalus } \\
\text { zachirus }\end{array}$ & Rex sole & 29 & 3.24 & 0.3744 & 0.0008 \\
\hline $\begin{array}{l}\text { Eastern } \\
\text { Bering Sea }\end{array}$ & $\begin{array}{l}\text { Hippoglossoides } \\
\text { elassodon }\end{array}$ & Flathead sole & 29 & 3.64 & 0.3645 & 0.0285 \\
\hline $\begin{array}{l}\text { Eastern } \\
\text { Bering Sea }\end{array}$ & $\begin{array}{l}\text { Hippoglossus } \\
\text { stenolepis }\end{array}$ & Pacific halibut & 29 & 4.13 & 0.5172 & 0.0060 \\
\hline $\begin{array}{l}\text { Eastern } \\
\text { Bering Sea }\end{array}$ & $\begin{array}{l}\text { Lepidopsetta } \\
\text { polyxystra }\end{array}$ & Northern rock sole & 29 & 3.30 & 0.5862 & 0.0801 \\
\hline $\begin{array}{l}\text { Eastern } \\
\text { Bering Sea }\end{array}$ & Limanda aspera & Yellowfin sole & 29 & 3.24 & -0.3300 & 0.1096 \\
\hline $\begin{array}{l}\text { Eastern } \\
\text { Bering Sea }\end{array}$ & $\begin{array}{l}\text { Microstomus } \\
\text { pacificus }\end{array}$ & Dover sole & 29 & 3.27 & 0.1968 & $*$ \\
\hline $\begin{array}{l}\text { Eastern } \\
\text { Bering Sea }\end{array}$ & Oncorhynchus & Pacific salmon & 29 & 3.95 & 0.1162 & 0.0042 \\
\hline $\begin{array}{l}\text { Eastern } \\
\text { Bering Sea }\end{array}$ & $\begin{array}{l}\text { Pleuronectes } \\
\text { quadrituberculatus }\end{array}$ & Alaska plaice & 29 & 3.10 & -0.4729 & 0.0239 \\
\hline $\begin{array}{l}\text { Eastern } \\
\text { Bering Sea }\end{array}$ & Pandalidae & Northern shrimps & 29 & 2.70 & 0.2808 & 0.0695 \\
\hline $\begin{array}{l}\text { Eastern } \\
\text { Bering Sea }\end{array}$ & $\begin{array}{l}\text { Paralithodes } \\
\text { camtschaticus }\end{array}$ & Red king crab & 29 & 2.82 & 0.1527 & 0.0043 \\
\hline $\begin{array}{l}\text { Eastern } \\
\text { Bering Sea }\end{array}$ & $\begin{array}{l}\text { Pleurogrammus } \\
\text { monopterygius }\end{array}$ & Atka mackerel & 29 & 3.33 & 0.3674 & 0.0045 \\
\hline $\begin{array}{l}\text { Eastern } \\
\text { Bering Sea }\end{array}$ & $\begin{array}{l}\text { Reinhardtius } \\
\text { hippoglossoides }\end{array}$ & Greenland halibut & 29 & 4.48 & 0.0049 & 0.0149 \\
\hline Eastern & Thaleichthys & Eulachon & 29 & 3.24 & -0.0739 & 0.0063 \\
\hline
\end{tabular}




\begin{tabular}{|c|c|c|c|c|c|c|}
\hline Bering Sea & pacificus & & & & & \\
\hline $\begin{array}{l}\text { Eastern } \\
\text { Bering Sea }\end{array}$ & $\begin{array}{l}\text { Theragra } \\
\text { chalcogramma }\end{array}$ & Alaska pollock & 29 & 3.45 & -0.2906 & 0.4792 \\
\hline $\begin{array}{l}\text { Eastern } \\
\text { Scotian } \\
\text { Shelf }\end{array}$ & Anarhichas lupus & Atlantic wolffish & 41 & 3.24 & -0.6220 & 0.0052 \\
\hline $\begin{array}{l}\text { Eastern } \\
\text { Scotian } \\
\text { Shelf }\end{array}$ & Argentina silus & Greater argentine & 41 & 3.31 & -0.4195 & 0.0027 \\
\hline $\begin{array}{l}\text { Eastern } \\
\text { Scotian } \\
\text { Shelf }\end{array}$ & Brosme brosme & Tusk & 41 & 4.00 & -0.6683 & 0.0022 \\
\hline $\begin{array}{l}\text { Eastern } \\
\text { Scotian } \\
\text { Shelf }\end{array}$ & $\begin{array}{l}\text { Chionoecetes } \\
\text { opilio }\end{array}$ & Queen crab & 41 & 2.30 & 0.7023 & 0.0049 \\
\hline $\begin{array}{l}\text { Eastern } \\
\text { Scotian } \\
\text { Shelf }\end{array}$ & Clupea harengus & Atlantic herring & 41 & 3.23 & 0.5925 & 0.0534 \\
\hline $\begin{array}{l}\text { Eastern } \\
\text { Scotian } \\
\text { Shelf }\end{array}$ & Gadus morhua & Atlantic cod & 41 & 4.42 & -0.4366 & 0.1551 \\
\hline $\begin{array}{l}\text { Eastern } \\
\text { Scotian } \\
\text { Shelf }\end{array}$ & $\begin{array}{l}\text { Glyptocephalus } \\
\text { cynoglossus }\end{array}$ & Witch flounder & 41 & 3.14 & -0.2195 & 0.0084 \\
\hline $\begin{array}{l}\text { Eastern } \\
\text { Scotian } \\
\text { Shelf }\end{array}$ & $\begin{array}{l}\text { Hippoglossoides } \\
\text { platessoides }\end{array}$ & American plaice & 41 & 3.65 & -0.5976 & 0.0756 \\
\hline $\begin{array}{l}\text { Eastern } \\
\text { Scotian } \\
\text { Shelf }\end{array}$ & $\begin{array}{l}\text { Hippoglossus } \\
\text { hippoglossus }\end{array}$ & Atlantic halibut & 41 & 4.53 & 0.1902 & 0.0058 \\
\hline $\begin{array}{l}\text { Eastern } \\
\text { Scotian } \\
\text { Shelf }\end{array}$ & Illex illecebrosus & $\begin{array}{l}\text { Northern shortfin } \\
\text { squid }\end{array}$ & 41 & 3.98 & -0.1195 & 0.0331 \\
\hline $\begin{array}{l}\text { Eastern } \\
\text { Scotian } \\
\text { Shelf }\end{array}$ & Limanda ferruginea & Yellowtail flounder & 41 & 3.22 & -0.4512 & 0.0411 \\
\hline $\begin{array}{l}\text { Eastern } \\
\text { Scotian } \\
\text { Shelf }\end{array}$ & $\begin{array}{l}\text { Lophius } \\
\text { americanus }\end{array}$ & American angler & 41 & 4.49 & -0.6073 & 0.0104 \\
\hline $\begin{array}{l}\text { Eastern } \\
\text { Scotian } \\
\text { Shelf }\end{array}$ & $\begin{array}{l}\text { Melanogrammus } \\
\text { aeglefinus }\end{array}$ & Haddock & 41 & 4.09 & 0.1171 & 0.1842 \\
\hline $\begin{array}{l}\text { Eastern } \\
\text { Scotian } \\
\text { Shelf }\end{array}$ & $\begin{array}{l}\text { Merluccius } \\
\text { bilinearis }\end{array}$ & Silver hake & 41 & 4.26 & 0.0756 & 0.0612 \\
\hline $\begin{array}{l}\text { Eastern } \\
\text { Scotian } \\
\text { Shelf }\end{array}$ & $\begin{array}{l}\text { Myoxocephalus } \\
\text { octodecemspinosus }\end{array}$ & Longhorn sculpin & 41 & 3.50 & -0.1146 & 0.0086 \\
\hline $\begin{array}{l}\text { Eastern } \\
\text { Scotian } \\
\text { Shelf }\end{array}$ & Myxine glutinosa & Hagfish & 41 & 3.45 & 0.2962 & 0.0001 \\
\hline $\begin{array}{l}\text { Eastern } \\
\text { Scotian } \\
\text { Shelf }\end{array}$ & Pandalus borealis & Northern prawn & 41 & 2.46 & 0.6212 & 0.0228 \\
\hline Eastern & Phycis chesteri & Longfin hake & 41 & 3.20 & -0.3927 & 0.0010 \\
\hline
\end{tabular}




\begin{tabular}{|c|c|c|c|c|c|c|}
\hline $\begin{array}{l}\text { Scotian } \\
\text { Shelf }\end{array}$ & & & & & & \\
\hline $\begin{array}{l}\text { Eastern } \\
\text { Scotian } \\
\text { Shelf }\end{array}$ & Pollachius virens & Saithe & 41 & 4.38 & -0.1220 & 0.0484 \\
\hline $\begin{array}{l}\text { Eastern } \\
\text { Scotian } \\
\text { Shelf }\end{array}$ & $\begin{array}{l}\text { Pseudopleuronectes } \\
\text { americanus }\end{array}$ & Winter flounder & 41 & 2.83 & -0.0829 & 0.0030 \\
\hline $\begin{array}{l}\text { Eastern } \\
\text { Scotian } \\
\text { Shelf }\end{array}$ & Leucoraja ocellata & Winter skate & 41 & 4.40 & -0.6171 & 0.0121 \\
\hline $\begin{array}{l}\text { Eastern } \\
\text { Scotian } \\
\text { Shelf }\end{array}$ & Amblyraja radiata & Starry ray & 41 & 4.00 & -0.7317 & 0.0349 \\
\hline $\begin{array}{l}\text { Eastern } \\
\text { Scotian } \\
\text { Shelf }\end{array}$ & $\begin{array}{l}\text { Reinhardtius } \\
\text { hippoglossoides }\end{array}$ & Greenland halibut & 41 & 4.48 & 0.5122 & 0.0062 \\
\hline $\begin{array}{l}\text { Eastern } \\
\text { Scotian } \\
\text { Shelf }\end{array}$ & Scomber scombrus & Atlantic mackerel & 41 & 3.18 & -0.2644 & 0.0071 \\
\hline $\begin{array}{l}\text { Eastern } \\
\text { Scotian } \\
\text { Shelf }\end{array}$ & $\begin{array}{l}\text { Scophthalmus } \\
\text { aquosus }\end{array}$ & Windowpane & 41 & 3.55 & -0.1901 & 0.0001 \\
\hline $\begin{array}{l}\text { Eastern } \\
\text { Scotian } \\
\text { Shelf }\end{array}$ & Sebastes & Redfishes & 41 & 3.79 & -0.2244 & 0.1706 \\
\hline $\begin{array}{l}\text { Eastern } \\
\text { Scotian } \\
\text { Shelf }\end{array}$ & Squalus acanthias & Piked dogfish & 41 & 4.30 & 0.1100 & 0.0154 \\
\hline $\begin{array}{l}\text { Eastern } \\
\text { Scotian } \\
\text { Shelf }\end{array}$ & $\begin{array}{l}\text { Tautogolabrus } \\
\text { adspersus }\end{array}$ & Cunner & 41 & 3.54 & 0.1335 & $*$ \\
\hline $\begin{array}{l}\text { Eastern } \\
\text { Scotian } \\
\text { Shelf }\end{array}$ & Urophycis chuss & Red hake & 41 & 3.60 & 0.0341 & 0.0028 \\
\hline $\begin{array}{l}\text { Eastern } \\
\text { Scotian } \\
\text { Shelf }\end{array}$ & Urophycis tenuis & White hake & 41 & 4.20 & -0.4780 & 0.0233 \\
\hline $\begin{array}{l}\text { English } \\
\text { Channel }\end{array}$ & $\begin{array}{l}\text { Chelidonichthys } \\
\text { cuculus }\end{array}$ & Red gurnard & 23 & 3.85 & -0.0988 & 0.0119 \\
\hline $\begin{array}{l}\text { English } \\
\text { Channel }\end{array}$ & $\begin{array}{l}\text { Chelidonichthys } \\
\text { lucernus }\end{array}$ & Tub gurnard & 23 & 3.65 & -0.2885 & 0.0038 \\
\hline $\begin{array}{l}\text { English } \\
\text { Channel }\end{array}$ & Clupea harengus & Atlantic herring & 23 & 3.23 & -0.5099 & 0.0401 \\
\hline $\begin{array}{l}\text { English } \\
\text { Channel }\end{array}$ & $\begin{array}{l}\text { Dicentrarchus } \\
\text { labrax }\end{array}$ & European seabass & 23 & 3.80 & 0.4941 & 0.0228 \\
\hline $\begin{array}{l}\text { English } \\
\text { Channel }\end{array}$ & Eutrigla gurnardus & Grey gurnard & 23 & 3.57 & -0.1383 & 0.0036 \\
\hline $\begin{array}{l}\text { English } \\
\text { Channel }\end{array}$ & Gadus morhua & Atlantic cod & 23 & 4.42 & -0.0356 & 0.0489 \\
\hline $\begin{array}{l}\text { English } \\
\text { Channel }\end{array}$ & Galeorhinus galeus & Tope shark & 23 & 4.21 & 0.0830 & 0.0350 \\
\hline $\begin{array}{l}\text { English } \\
\text { Channel }\end{array}$ & Hyperoplus & Sand lances & 23 & 3.10 & -0.2174 & 0.0018 \\
\hline English & Limanda limanda & Common dab & 23 & 3.29 & -0.0119 & 0.0251 \\
\hline
\end{tabular}




\begin{tabular}{|c|c|c|c|c|c|c|}
\hline Channel & & & & & & \\
\hline $\begin{array}{l}\text { English } \\
\text { Channel }\end{array}$ & Loligo & Common squids & 23 & 3.99 & 0.1621 & 0.0284 \\
\hline $\begin{array}{l}\text { English } \\
\text { Channel }\end{array}$ & Maja squinado & Spinous spider crab & 23 & 2.30 & 0.2632 & 0.0097 \\
\hline $\begin{array}{l}\text { English } \\
\text { Channel }\end{array}$ & $\begin{array}{l}\text { Merlangius } \\
\text { merlangus }\end{array}$ & Whiting & 23 & 4.29 & 0.3202 & 0.0782 \\
\hline $\begin{array}{l}\text { English } \\
\text { Channel }\end{array}$ & Microstomus kitt & Lemon sole & 23 & 3.22 & -0.0909 & 0.0105 \\
\hline $\begin{array}{l}\text { English } \\
\text { Channel }\end{array}$ & Mullus surmuletus & Surmullet & 23 & 3.35 & 0.2253 & 0.0073 \\
\hline $\begin{array}{l}\text { English } \\
\text { Channel }\end{array}$ & Mustelus asterias & $\begin{array}{l}\text { Starry smooth- } \\
\text { hound }\end{array}$ & 23 & 3.71 & 0.4783 & 0.0274 \\
\hline $\begin{array}{l}\text { English } \\
\text { Channel }\end{array}$ & Mustelus mustelus & Smooth-hound & 23 & 3.83 & 0.0095 & 0.0185 \\
\hline $\begin{array}{l}\text { English } \\
\text { Channel }\end{array}$ & Necora puber & Velvet swimcrab & 23 & 2.60 & -0.1429 & 0.0114 \\
\hline $\begin{array}{l}\text { English } \\
\text { Channel }\end{array}$ & Platichthys flesus & European flounder & 23 & 3.53 & 0.1462 & 0.0137 \\
\hline $\begin{array}{l}\text { English } \\
\text { Channel }\end{array}$ & $\begin{array}{l}\text { Pleuronectes } \\
\text { platessa }\end{array}$ & European plaice & 23 & 3.26 & 0.2174 & 0.0331 \\
\hline $\begin{array}{l}\text { English } \\
\text { Channel }\end{array}$ & Raja clavata & Thornback ray & 23 & 3.60 & 0.1542 & 0.0251 \\
\hline $\begin{array}{l}\text { English } \\
\text { Channel }\end{array}$ & Sardina pilchardus & European pilchard & 23 & 3.10 & -0.4150 & 0.0106 \\
\hline $\begin{array}{l}\text { English } \\
\text { Channel }\end{array}$ & Scomber scombrus & Atlantic mackerel & 23 & 3.18 & -0.1383 & 0.0702 \\
\hline $\begin{array}{l}\text { English } \\
\text { Channel }\end{array}$ & $\begin{array}{l}\text { Scyliorhinus } \\
\text { canicula }\end{array}$ & $\begin{array}{l}\text { Smallspotted } \\
\text { catshark }\end{array}$ & 23 & 3.58 & 0.3597 & 0.0704 \\
\hline $\begin{array}{l}\text { English } \\
\text { Channel }\end{array}$ & $\begin{array}{l}\text { Scyliorhinus } \\
\text { stellaris }\end{array}$ & Nursehound & 23 & 4.03 & 0.3834 & 0.0227 \\
\hline $\begin{array}{l}\text { English } \\
\text { Channel }\end{array}$ & Sepia officinalis & Common cuttlefish & 23 & 3.55 & 0.0119 & 0.0102 \\
\hline $\begin{array}{l}\text { English } \\
\text { Channel }\end{array}$ & Solea solea & Common sole & 23 & 3.17 & 0.1542 & 0.0058 \\
\hline $\begin{array}{l}\text { English } \\
\text { Channel }\end{array}$ & $\begin{array}{l}\text { Spondyliosoma } \\
\text { cantharus }\end{array}$ & Black seabream & 23 & 3.34 & 0.3202 & 0.0189 \\
\hline $\begin{array}{l}\text { English } \\
\text { Channel }\end{array}$ & Sprattus sprattus & Baltic sprat & 23 & 3.37 & -0.0514 & 0.0339 \\
\hline $\begin{array}{l}\text { English } \\
\text { Channel }\end{array}$ & $\begin{array}{l}\text { Trachurus } \\
\text { trachurus }\end{array}$ & $\begin{array}{l}\text { Atlantic horse } \\
\text { mackerel }\end{array}$ & 23 & 3.64 & -0.5494 & 0.1596 \\
\hline $\begin{array}{l}\text { English } \\
\text { Channel }\end{array}$ & Trisopterus luscus & Pouting & 23 & 3.73 & 0.2253 & 0.1371 \\
\hline $\begin{array}{l}\text { English } \\
\text { Channel }\end{array}$ & Zeus faber & John dory & 23 & 4.50 & -0.0751 & 0.0043 \\
\hline $\begin{array}{l}\text { Guinean } \\
\text { Shelf }\end{array}$ & $\begin{array}{l}\text { Alectis } \\
\text { alexandrinus }\end{array}$ & African threadfish & 25 & 3.60 & -0.0526 & 0.0156 \\
\hline $\begin{array}{l}\text { Guinean } \\
\text { Shelf }\end{array}$ & Arius latiscutatus & $\begin{array}{l}\text { Rough-head sea } \\
\text { catfish }\end{array}$ & 25 & 3.30 & -0.5906 & 0.0347 \\
\hline $\begin{array}{l}\text { Guinean } \\
\text { Shelf }\end{array}$ & $\begin{array}{l}\text { Brachydeuterus } \\
\text { auritus }\end{array}$ & Bigeye grunt & 25 & 3.03 & -0.1345 & 0.0758 \\
\hline $\begin{array}{l}\text { Guinean } \\
\text { Shelf }\end{array}$ & Cararius heudelotii & $\begin{array}{l}\text { Smoothmouth sea } \\
\text { catfish }\end{array}$ & 25 & 3.80 & -0.4971 & 0.0143 \\
\hline $\begin{array}{l}\text { Guinean } \\
\text { Shelf }\end{array}$ & $\begin{array}{l}\text { Chloroscombrus } \\
\text { chrysurus }\end{array}$ & Atlantic bumper & 25 & 3.21 & -0.0877 & 0.1395 \\
\hline
\end{tabular}




\begin{tabular}{|c|c|c|c|c|c|c|}
\hline $\begin{array}{l}\text { Guinean } \\
\text { Shelf }\end{array}$ & $\begin{array}{l}\text { Cynoglossus } \\
\text { senegalensis }\end{array}$ & $\begin{array}{l}\text { Senegalese } \\
\text { tonguesole }\end{array}$ & 25 & 3.60 & -0.1579 & 0.0146 \\
\hline $\begin{array}{l}\text { Guinean } \\
\text { Shelf }\end{array}$ & Dasyatis margarita & Daisy stingray & 25 & 3.40 & -0.4386 & 0.0946 \\
\hline $\begin{array}{l}\text { Guinean } \\
\text { Shelf }\end{array}$ & Drepane africana & African sicklefish & 25 & 3.10 & -0.5439 & 0.0356 \\
\hline $\begin{array}{l}\text { Guinean } \\
\text { Shelf }\end{array}$ & Ephippion guttifer & Prickly puffer & 25 & 3.60 & -0.3333 & 0.0244 \\
\hline $\begin{array}{l}\text { Guinean } \\
\text { Shelf }\end{array}$ & $\begin{array}{l}\text { Eucinostomus } \\
\text { melanopterus }\end{array}$ & Flagfin mojarra & 25 & 3.40 & -0.5948 & 0.0162 \\
\hline $\begin{array}{l}\text { Guinean } \\
\text { Shelf }\end{array}$ & $\begin{array}{l}\text { Galeoides } \\
\text { decadactylus }\end{array}$ & $\begin{array}{l}\text { Lesser African } \\
\text { threadfin }\end{array}$ & 25 & 3.57 & -0.4737 & 0.1236 \\
\hline $\begin{array}{l}\text { Guinean } \\
\text { Shelf }\end{array}$ & Ilisha africana & West African ilisha & 25 & 3.19 & -0.2047 & 0.0763 \\
\hline $\begin{array}{l}\text { Guinean } \\
\text { Shelf }\end{array}$ & $\begin{array}{l}\text { Pagrus } \\
\text { caeruleostictus }\end{array}$ & $\begin{array}{l}\text { Bluespotted } \\
\text { seabream }\end{array}$ & 25 & 3.60 & -0.0292 & 0.0504 \\
\hline $\begin{array}{l}\text { Guinean } \\
\text { Shelf }\end{array}$ & $\begin{array}{l}\text { Pentanemus } \\
\text { quinquarius }\end{array}$ & Royal threadfin & 25 & 3.56 & -0.4503 & 0.0410 \\
\hline $\begin{array}{l}\text { Guinean } \\
\text { Shelf }\end{array}$ & Pomadasys jubelini & Sompat grunt & 25 & 3.33 & -0.5205 & 0.0350 \\
\hline $\begin{array}{l}\text { Guinean } \\
\text { Shelf }\end{array}$ & $\begin{array}{l}\text { Pseudotolithus } \\
\text { elongatus }\end{array}$ & Bobo croaker & 25 & 4.06 & -0.5439 & 0.0751 \\
\hline $\begin{array}{l}\text { Guinean } \\
\text { Shelf }\end{array}$ & $\begin{array}{l}\begin{array}{l}\text { Pseudotolithus } \\
\text { senegalensis }\end{array} \\
\end{array}$ & Cassava croaker & 25 & 3.84 & -0.5556 & 0.0437 \\
\hline $\begin{array}{l}\text { Guinean } \\
\text { Shelf }\end{array}$ & $\begin{array}{l}\text { Pseudotolithus } \\
\text { senegallus }\end{array}$ & Law croaker & 25 & 3.89 & -0.6725 & 0.0229 \\
\hline $\begin{array}{l}\text { Guinean } \\
\text { Shelf }\end{array}$ & $\begin{array}{l}\text { Pseudotolithus } \\
\text { typus }\end{array}$ & Longneck croaker & 25 & 3.70 & -0.6023 & 0.0483 \\
\hline $\begin{array}{l}\text { Guinean } \\
\text { Shelf }\end{array}$ & Trichiurus lepturus & Largehead hairtail & 25 & 4.45 & -0.1930 & 0.0185 \\
\hline $\begin{array}{l}\text { Gulf of } \\
\text { Cadiz }\end{array}$ & $\begin{array}{l}\text { Alloteuthis } \\
\text { subulata }\end{array}$ & $\begin{array}{l}\text { European common } \\
\text { squid }\end{array}$ & 18 & 4.00 & -0.2680 & 0.0196 \\
\hline $\begin{array}{l}\text { Gulf of } \\
\text { Cadiz }\end{array}$ & $\begin{array}{l}\text { Cepola } \\
\text { macrophthalma }\end{array}$ & Red bandfish & 18 & 3.20 & -0.1111 & 0.0386 \\
\hline $\begin{array}{l}\text { Gulf of } \\
\text { Cadiz }\end{array}$ & Eledone cirrhosa & Horned octopus & 18 & 3.70 & -0.2288 & 0.0212 \\
\hline $\begin{array}{l}\text { Gulf of } \\
\text { Cadiz }\end{array}$ & Eledone moschata & Musky octopus & 18 & 3.65 & -0.3856 & 0.0947 \\
\hline $\begin{array}{l}\text { Gulf of } \\
\text { Cadiz }\end{array}$ & Illex coindetii & $\begin{array}{l}\text { Broadtail shortfin } \\
\text { squid }\end{array}$ & 18 & 4.15 & -0.1324 & 0.1255 \\
\hline $\begin{array}{l}\text { Gulf of } \\
\text { Cadiz }\end{array}$ & Liza aurata & Golden grey mullet & 18 & 3.01 & -0.3905 & 0.0059 \\
\hline $\begin{array}{l}\text { Gulf of } \\
\text { Cadiz }\end{array}$ & Liza ramada & Thinlip grey mullet & 18 & 2.16 & -0.2167 & 0.0254 \\
\hline $\begin{array}{l}\text { Gulf of } \\
\text { Cadiz }\end{array}$ & Lophius piscatorius & Angler & 18 & 4.49 & -0.2571 & 0.0129 \\
\hline $\begin{array}{l}\text { Gulf of } \\
\text { Cadiz }\end{array}$ & $\begin{array}{l}\text { Micromesistius } \\
\text { poutassou }\end{array}$ & Blue whiting & 18 & 4.01 & -0.0458 & 0.3238 \\
\hline $\begin{array}{l}\text { Gulf of } \\
\text { Cadiz }\end{array}$ & Scorpaena notata & $\begin{array}{l}\text { Small red } \\
\text { scorpionfish }\end{array}$ & 18 & 3.50 & -0.2288 & 0.0061 \\
\hline $\begin{array}{l}\text { Gulf of } \\
\text { Cadiz }\end{array}$ & Sepia elegans & Elegant cuttlefish & 18 & 4.00 & 0.0065 & 0.0051 \\
\hline $\begin{array}{l}\text { Gulf of } \\
\text { Cadiz }\end{array}$ & Solea solea & Common sole & 18 & 3.17 & -0.0588 & 0.0030 \\
\hline Gulf of & Trachurus & Atlantic horse & 18 & 3.64 & -0.1503 & 0.3182 \\
\hline
\end{tabular}




\begin{tabular}{|c|c|c|c|c|c|c|}
\hline Cadiz & trachurus & mackerel & & & & \\
\hline Irish Sea & Clupea harengus & Atlantic herring & 18 & 3.23 & 0.2680 & 0.1038 \\
\hline Irish Sea & Gadus morhua & Atlantic cod & 18 & 4.42 & -0.6993 & 0.0218 \\
\hline Irish Sea & Leucoraja naevus & Cuckoo ray & 18 & 3.94 & -0.4902 & 0.0042 \\
\hline Irish Sea & $\begin{array}{l}\text { Melanogrammus } \\
\text { aeglefinus }\end{array}$ & Haddock & 18 & 4.09 & 0.1765 & 0.0015 \\
\hline Irish Sea & $\begin{array}{l}\text { Merlangius } \\
\text { merlangus }\end{array}$ & Whiting & 18 & 4.29 & -0.3464 & 0.0105 \\
\hline Irish Sea & $\begin{array}{l}\text { Pleuronectes } \\
\text { platessa }\end{array}$ & European plaice & 18 & 3.26 & 0.6863 & 0.1065 \\
\hline Irish Sea & $\begin{array}{l}\text { Pollachius } \\
\text { pollachius }\end{array}$ & Pollock & 18 & 4.15 & -0.1774 & 0.0001 \\
\hline Irish Sea & Raja brachyura & Blonde ray & 18 & 3.98 & -0.0980 & 0.0026 \\
\hline Irish Sea & Raja clavata & Thornback ray & 18 & 3.60 & 0.3987 & 0.0145 \\
\hline Irish Sea & Raja microocellata & Small-eyed ray & 18 & 3.89 & -0.3080 & * \\
\hline Irish Sea & Raja montagui & Spotted ray & 18 & 3.57 & 0.3672 & 0.0065 \\
\hline Irish Sea & Scomber scombrus & Atlantic mackerel & 18 & 3.18 & -0.0141 & * \\
\hline Irish Sea & Solea solea & Common sole & 18 & 3.17 & -0.5948 & 0.0213 \\
\hline Irish Sea & Sprattus sprattus & European sprat & 18 & 3.00 & 0.1443 & 0.7065 \\
\hline Irish Sea & Squalus acanthias & Piked dogfish & 18 & 4.30 & -0.4518 & 0.0001 \\
\hline $\begin{array}{l}\text { North } \\
\text { Aegean }\end{array}$ & Boops boops & Bogue & 4 & 3.00 & 1.0000 & 0.0032 \\
\hline $\begin{array}{l}\text { North } \\
\text { Aegean }\end{array}$ & Citharus linguatula & Spotted flounder & 4 & 3.97 & -0.6667 & 0.0108 \\
\hline $\begin{array}{l}\text { North } \\
\text { Aegean }\end{array}$ & Conger conger & European conger & 4 & 4.29 & 0.6667 & 0.0035 \\
\hline $\begin{array}{l}\text { North } \\
\text { Aegean }\end{array}$ & Dentex dentex & Common dentex & 4 & 4.50 & -0.3333 & 0.0005 \\
\hline $\begin{array}{l}\text { North } \\
\text { Aegean }\end{array}$ & Dentex maroccanus & Morocco dentex & 4 & 3.85 & 0.0000 & 0.0017 \\
\hline $\begin{array}{l}\text { North } \\
\text { Aegean }\end{array}$ & Diplodus annularis & Annular seabream & 4 & 3.40 & -0.3333 & 0.0236 \\
\hline $\begin{array}{l}\text { North } \\
\text { Aegean }\end{array}$ & Diplodus vulgaris & $\begin{array}{l}\text { Common two- } \\
\text { banded seabream }\end{array}$ & 4 & 3.24 & 0.6667 & 0.0016 \\
\hline $\begin{array}{l}\text { North } \\
\text { Aegean }\end{array}$ & Eledone cirrhosa & Horned octopus & 4 & 3.70 & 0.0000 & 0.0235 \\
\hline $\begin{array}{l}\text { North } \\
\text { Aegean }\end{array}$ & Eledone moschata & Musky octopus & 4 & 3.65 & -0.6667 & 0.0470 \\
\hline $\begin{array}{l}\text { North } \\
\text { Aegean }\end{array}$ & Eutrigla gurnardus & Grey gurnard & 4 & 3.57 & -0.6667 & 0.0039 \\
\hline $\begin{array}{l}\text { North } \\
\text { Aegean }\end{array}$ & $\begin{array}{l}\text { Gaidropsarus } \\
\text { mediterraneus }\end{array}$ & Shore rockling & 4 & 3.38 & 0.0000 & 0.0002 \\
\hline $\begin{array}{l}\text { North } \\
\text { Aegean }\end{array}$ & $\begin{array}{l}\text { Helicolenus } \\
\text { dactylopterus }\end{array}$ & Blackbelly rosefish & 4 & 3.81 & -0.6667 & 0.0007 \\
\hline $\begin{array}{l}\text { North } \\
\text { Aegean }\end{array}$ & Illex coindetii & $\begin{array}{l}\text { Broadtail shortfin } \\
\text { squid }\end{array}$ & 4 & 4.15 & 0.0000 & 0.0521 \\
\hline $\begin{array}{l}\text { North } \\
\text { Aegean }\end{array}$ & $\begin{array}{l}\text { Lepidopus } \\
\text { caudatus }\end{array}$ & Silver scabbardfish & 4 & 3.85 & 0.3333 & 0.0008 \\
\hline $\begin{array}{l}\text { North } \\
\text { Aegean }\end{array}$ & Loligo vulgaris & European squid & 4 & 4.10 & -0.6667 & 0.0022 \\
\hline $\begin{array}{l}\text { North } \\
\text { Aegean }\end{array}$ & Lophius budegassa & Black-bellied angler & 4 & 4.48 & -0.3333 & 0.0384 \\
\hline $\begin{array}{l}\text { North } \\
\text { Aegean }\end{array}$ & Lophius piscatorius & Angler & 4 & 4.49 & 0.3333 & 0.0164 \\
\hline
\end{tabular}




\begin{tabular}{|c|c|c|c|c|c|c|}
\hline $\begin{array}{l}\text { North } \\
\text { Aegean }\end{array}$ & $\begin{array}{l}\text { Merlangius } \\
\text { merlangus }\end{array}$ & Whiting & 4 & 4.29 & -0.6667 & 0.0012 \\
\hline $\begin{array}{l}\text { North } \\
\text { Aegean }\end{array}$ & $\begin{array}{l}\text { Merluccius } \\
\text { merluccius }\end{array}$ & European hake & 4 & 4.42 & 0.0000 & 0.0925 \\
\hline $\begin{array}{l}\text { North } \\
\text { Aegean }\end{array}$ & $\begin{array}{l}\text { Micromesistius } \\
\text { poutassou }\end{array}$ & Blue whiting & 4 & 4.01 & -0.6667 & 0.0489 \\
\hline $\begin{array}{l}\text { North } \\
\text { Aegean }\end{array}$ & Mullus barbatus & Red mullet & 4 & 3.33 & -1.0000 & 0.0425 \\
\hline $\begin{array}{l}\text { North } \\
\text { Aegean }\end{array}$ & Mullus surmuletus & Surmullet & 4 & 3.35 & 0.6667 & 0.0016 \\
\hline $\begin{array}{l}\text { North } \\
\text { Aegean }\end{array}$ & $\begin{array}{l}\text { Nephrops } \\
\text { norvegicus }\end{array}$ & Norway lobster & 4 & 2.88 & 0.3333 & 0.0045 \\
\hline $\begin{array}{l}\text { North } \\
\text { Aegean }\end{array}$ & Octopus vulgaris & common octopus & 4 & 3.60 & -0.6667 & 0.0747 \\
\hline $\begin{array}{l}\text { North } \\
\text { Aegean }\end{array}$ & Pagellus acarne & Axillary seabream & 4 & 3.48 & -0.6667 & 0.0174 \\
\hline $\begin{array}{l}\text { North } \\
\text { Aegean }\end{array}$ & Pagellus bogaraveo & Blackspot seabream & 4 & 3.73 & 0.0000 & 0.0089 \\
\hline $\begin{array}{l}\text { North } \\
\text { Aegean }\end{array}$ & Pagellus erythrinus & Common pandora & 4 & 3.40 & -0.3333 & 0.0041 \\
\hline $\begin{array}{l}\text { North } \\
\text { Aegean }\end{array}$ & Pagrus pagrus & Red porgy & 4 & 3.65 & 1.0000 & 0.0054 \\
\hline $\begin{array}{l}\text { North } \\
\text { Aegean }\end{array}$ & $\begin{array}{l}\text { Parapenaeus } \\
\text { longirostris }\end{array}$ & $\begin{array}{l}\text { deep-water rose } \\
\text { shrimp }\end{array}$ & 4 & 3.30 & -0.6667 & 0.1936 \\
\hline $\begin{array}{l}\text { North } \\
\text { Aegean }\end{array}$ & Penaeus kerathurus & Caramote prawn & 4 & 2.10 & -1.0000 & 0.0076 \\
\hline $\begin{array}{l}\text { North } \\
\text { Aegean }\end{array}$ & Phycis blennoides & Greater forkbeard & 4 & 3.73 & 0.6667 & 0.0049 \\
\hline $\begin{array}{l}\text { North } \\
\text { Aegean }\end{array}$ & Phycis phycis & Forkbeard & 4 & 4.26 & -0.6667 & 0.0008 \\
\hline $\begin{array}{l}\text { North } \\
\text { Aegean }\end{array}$ & Raja clavata & Thornback ray & 4 & 3.60 & -0.3333 & 0.0258 \\
\hline $\begin{array}{l}\text { North } \\
\text { Aegean }\end{array}$ & Raja miraletus & Brown ray & 4 & 3.80 & 0.0000 & 0.0020 \\
\hline $\begin{array}{l}\text { North } \\
\text { Aegean }\end{array}$ & Scomber scombrus & Atlantic mackerel & 4 & 3.18 & 0.6667 & 0.0200 \\
\hline $\begin{array}{l}\text { North } \\
\text { Aegean }\end{array}$ & $\begin{array}{l}\text { Scophthalmus } \\
\text { rhombus }\end{array}$ & Brill & 4 & 3.79 & -0.3333 & 0.0013 \\
\hline $\begin{array}{l}\text { North } \\
\text { Aegean }\end{array}$ & Scorpaena elongata & Slender rockfish & 4 & 3.86 & 0.0000 & 0.0002 \\
\hline $\begin{array}{l}\text { North } \\
\text { Aegean }\end{array}$ & Scorpaena notata & $\begin{array}{l}\begin{array}{l}\text { Small red } \\
\text { scorpionfish }\end{array} \\
\end{array}$ & 4 & 3.50 & -1.0000 & 0.0152 \\
\hline $\begin{array}{l}\text { North } \\
\text { Aegean }\end{array}$ & Scorpaena porcus & Black scorpionfish & 4 & 3.93 & -0.3333 & 0.0031 \\
\hline $\begin{array}{l}\text { North } \\
\text { Aegean }\end{array}$ & $\begin{array}{l}\text { Scyliorhinus } \\
\text { canicula }\end{array}$ & $\begin{array}{l}\text { Smallspotted } \\
\text { catshark }\end{array}$ & 4 & 3.58 & -1.0000 & 0.0511 \\
\hline $\begin{array}{l}\text { North } \\
\text { Aegean }\end{array}$ & Sepia elegans & Elegant cuttlefish & 4 & 4.00 & -0.6667 & 0.0032 \\
\hline $\begin{array}{l}\text { North } \\
\text { Aegean }\end{array}$ & Sepia officinalis & Common cuttlefish & 4 & 3.55 & -0.6667 & 0.0063 \\
\hline $\begin{array}{l}\text { North } \\
\text { Aegean }\end{array}$ & Sepia orbignyana & pink cuttlefish & 4 & 3.55 & -0.3333 & 0.0017 \\
\hline $\begin{array}{l}\text { North } \\
\text { Aegean }\end{array}$ & Serranus cabrilla & Comber & 4 & 3.35 & -0.6667 & 0.0075 \\
\hline North & Spicara flexuosa & Blotched picarel & 4 & 3.50 & 0.6667 & 0.0072 \\
\hline
\end{tabular}




\begin{tabular}{|c|c|c|c|c|c|c|}
\hline Aegean & & & & & & \\
\hline $\begin{array}{l}\text { North } \\
\text { Aegean }\end{array}$ & Spicara smaris & Picarel & 4 & 3.00 & 0.0000 & 0.0028 \\
\hline $\begin{array}{l}\text { North } \\
\text { Aegean }\end{array}$ & $\begin{array}{l}\text { Spondyliosoma } \\
\text { cantharus }\end{array}$ & Black seabream & 4 & 3.34 & 0.6667 & 0.0003 \\
\hline $\begin{array}{l}\text { North } \\
\text { Aegean }\end{array}$ & Squilla mantis & $\begin{array}{l}\text { Spottail mantis } \\
\text { squillid }\end{array}$ & 4 & 2.60 & 0.0000 & 0.0040 \\
\hline $\begin{array}{l}\text { North } \\
\text { Aegean }\end{array}$ & Trachinus draco & Greater weever & 4 & 4.18 & 0.3333 & 0.0067 \\
\hline $\begin{array}{l}\text { North } \\
\text { Aegean }\end{array}$ & $\begin{array}{l}\text { Trachurus } \\
\text { mediterraneus }\end{array}$ & $\begin{array}{l}\text { Mediterranean } \\
\text { horse mackerel }\end{array}$ & 4 & 3.47 & -0.3333 & 0.0058 \\
\hline $\begin{array}{l}\text { North } \\
\text { Aegean }\end{array}$ & $\begin{array}{l}\text { Trachurus } \\
\text { trachurus }\end{array}$ & $\begin{array}{l}\text { Atlantic horse } \\
\text { mackerel }\end{array}$ & 4 & 3.64 & -0.3333 & 0.0374 \\
\hline $\begin{array}{l}\text { North } \\
\text { Aegean }\end{array}$ & Trigla lucerna & Tub gurnard & 4 & 3.65 & -0.3333 & 0.0124 \\
\hline $\begin{array}{l}\text { North } \\
\text { Aegean }\end{array}$ & Trigla lyra & Piper gurnard & 4 & 3.46 & -0.3333 & 0.0022 \\
\hline $\begin{array}{l}\text { North } \\
\text { Aegean }\end{array}$ & $\begin{array}{l}\text { Trigloporus } \\
\text { lastoviza }\end{array}$ & Streaked gurnard & 4 & 3.50 & -0.6667 & 0.0046 \\
\hline $\begin{array}{l}\text { North } \\
\text { Aegean }\end{array}$ & $\begin{array}{l}\text { Trisopterus } \\
\text { minutus capelanus }\end{array}$ & Poor cod & 4 & 3.65 & -1.0000 & 0.0289 \\
\hline $\begin{array}{l}\text { North } \\
\text { Aegean }\end{array}$ & $\begin{array}{l}\text { Uranoscopus } \\
\text { scaber }\end{array}$ & Stargazer & 4 & 4.38 & 0.0000 & 0.0022 \\
\hline $\begin{array}{l}\text { North } \\
\text { Aegean }\end{array}$ & Zeus faber & John dory & 4 & 4.50 & 0.3333 & 0.0092 \\
\hline $\begin{array}{l}\text { Northern } \\
\text { Humboldt } \\
\text { Current }\end{array}$ & Anchoa nasus & Longnose anchovy & 13 & 3.30 & -0.5152 & 0.0277 \\
\hline $\begin{array}{l}\text { Northern } \\
\text { Humboldt } \\
\text { Current }\end{array}$ & Dosidicus gigas & Jumbo flying squid & 11 & 4.20 & 0.4545 & 0.0413 \\
\hline $\begin{array}{l}\text { Northern } \\
\text { Humboldt } \\
\text { Current }\end{array}$ & Engraulis ringens & Anchoveta & 25 & 3.50 & 0.3800 & 0.4869 \\
\hline $\begin{array}{l}\text { Northern } \\
\text { Humboldt } \\
\text { Current }\end{array}$ & $\begin{array}{l}\text { Galeichthys } \\
\text { peruvianus }\end{array}$ & Peruvian sea catfish & 11 & 3.70 & 0.0909 & 0.0226 \\
\hline $\begin{array}{l}\text { Northern } \\
\text { Humboldt } \\
\text { Current }\end{array}$ & Merluccius gayi & South Pacific hake & 27 & 4.00 & -0.3105 & 0.0161 \\
\hline $\begin{array}{l}\text { Northern } \\
\text { Humboldt } \\
\text { Current }\end{array}$ & $\begin{array}{l}\text { Normanichthys } \\
\text { crokeri }\end{array}$ & Mote sculpin & 11 & 3.00 & 0.1826 & 0.0022 \\
\hline $\begin{array}{l}\text { Northern } \\
\text { Humboldt } \\
\text { Current }\end{array}$ & $\begin{array}{l}\text { Prionotus } \\
\text { stephanophrys }\end{array}$ & Lumptail searobin & 17 & 3.60 & -0.2222 & 0.0066 \\
\hline $\begin{array}{l}\text { Northern } \\
\text { Humboldt } \\
\text { Current }\end{array}$ & Sardinops sagax & Pacific sardine & 24 & 3.30 & -0.6740 & 0.1394 \\
\hline $\begin{array}{l}\text { Northern } \\
\text { Humboldt } \\
\text { Current }\end{array}$ & Scomber japonicus & Chub mackerel & 27 & 3.70 & -0.4758 & 0.0729 \\
\hline $\begin{array}{l}\text { Northern } \\
\text { Humboldt } \\
\text { Current }\end{array}$ & Trachurus murphyi & Jack mackerel & 27 & 3.90 & -0.5442 & 0.1843 \\
\hline
\end{tabular}




\begin{tabular}{|c|c|c|c|c|c|c|}
\hline $\begin{array}{l}\text { North } \\
\text { Ionian }\end{array}$ & $\begin{array}{l}\text { Engraulis } \\
\text { encrasicolus }\end{array}$ & European anchovy & 45 & 3.11 & -0.5758 & 0.3157 \\
\hline $\begin{array}{l}\text { North } \\
\text { Ionian }\end{array}$ & $\begin{array}{l}\text { Katsuwonus } \\
\text { pelamis }\end{array}$ & Skipjack tuna & 45 & 4.35 & -0.1414 & 0.0221 \\
\hline $\begin{array}{l}\text { North } \\
\text { Ionian }\end{array}$ & $\begin{array}{l}\text { Merluccius } \\
\text { merluccius }\end{array}$ & European hake & 45 & 4.42 & -0.1434 & 0.0702 \\
\hline $\begin{array}{l}\text { North } \\
\text { Ionian }\end{array}$ & Sardina pilchardus & European pilchard & 45 & 3.10 & -0.5152 & 0.5661 \\
\hline $\begin{array}{l}\text { North } \\
\text { Ionian }\end{array}$ & Xiphias gladius & Swordfish & 45 & 4.49 & -0.7192 & 0.0259 \\
\hline $\begin{array}{l}\text { North- } \\
\text { central } \\
\text { Adriatic }\end{array}$ & $\begin{array}{l}\text { Chlamys } \\
\text { opercularis }\end{array}$ & Queen scallop & 22 & 2.10 & -0.3216 & 0.0005 \\
\hline $\begin{array}{l}\text { North- } \\
\text { central } \\
\text { Adriatic }\end{array}$ & Conger conger & European conger & 24 & 4.29 & -0.0762 & 0.0001 \\
\hline $\begin{array}{l}\text { North- } \\
\text { central } \\
\text { Adriatic }\end{array}$ & $\begin{array}{l}\text { Engraulis } \\
\text { encrasicolus }\end{array}$ & European anchovy & 32 & 3.11 & -0.5524 & 0.8075 \\
\hline $\begin{array}{l}\text { North- } \\
\text { central } \\
\text { Adriatic }\end{array}$ & Lophius & Monkfishes & 24 & 4.46 & -0.3905 & 0.0005 \\
\hline $\begin{array}{l}\text { North- } \\
\text { central } \\
\text { Adriatic }\end{array}$ & $\begin{array}{l}\text { Merluccius } \\
\text { merluccius }\end{array}$ & European hake & 24 & 4.42 & 0.1238 & 0.0034 \\
\hline $\begin{array}{l}\text { North- } \\
\text { central } \\
\text { Adriatic }\end{array}$ & Mullus & Western goatfishes & 24 & 3.29 & 0.2000 & 0.0024 \\
\hline $\begin{array}{l}\text { North- } \\
\text { central } \\
\text { Adriatic }\end{array}$ & $\begin{array}{l}\text { Nephrops } \\
\text { norvegicus }\end{array}$ & Norway lobster & 24 & 2.88 & -0.2762 & 0.0005 \\
\hline $\begin{array}{l}\text { North- } \\
\text { central } \\
\text { Adriatic }\end{array}$ & Squilla mantis & $\begin{array}{l}\text { Spottail mantis } \\
\text { squillid }\end{array}$ & 24 & 2.60 & 0.0667 & 0.0010 \\
\hline $\begin{array}{l}\text { North- } \\
\text { central } \\
\text { Adriatic }\end{array}$ & Raja & Skates & 24 & 3.82 & -0.3333 & 0.0005 \\
\hline $\begin{array}{l}\text { North- } \\
\text { central } \\
\text { Adriatic }\end{array}$ & Sardina pilchardus & European pilchard & 31 & 3.10 & -0.0882 & 0.1808 \\
\hline $\begin{array}{l}\text { North- } \\
\text { central } \\
\text { Adriatic }\end{array}$ & Scomber & Mackerels & 24 & 3.65 & 0.4381 & 0.0008 \\
\hline $\begin{array}{l}\text { North- } \\
\text { central } \\
\text { Adriatic }\end{array}$ & $\begin{array}{l}\text { Scophthalmus } \\
\text { rhombus }\end{array}$ & Brill & 24 & 3.79 & -0.1167 & $*$ \\
\hline $\begin{array}{l}\text { North- } \\
\text { central } \\
\text { Adriatic }\end{array}$ & Spicara smaris & Picarel & 24 & 3.00 & -0.3333 & 0.0001 \\
\hline $\begin{array}{l}\text { North- } \\
\text { central } \\
\text { Adriatic }\end{array}$ & Sprattus sprattus & European sprat & 24 & 3.00 & -0.0762 & 0.0014 \\
\hline $\begin{array}{l}\text { North- } \\
\text { central } \\
\text { Adriatic }\end{array}$ & Trachurus & $\begin{array}{l}\text { Jack and horse } \\
\text { mackerels }\end{array}$ & 24 & 3.70 & -0.2667 & 0.0005 \\
\hline
\end{tabular}




\begin{tabular}{|c|c|c|c|c|c|c|}
\hline $\begin{array}{l}\text { Northeast } \\
\text { U.S. }\end{array}$ & Alosa aestivalis & Blueback shad & 47 & 3.60 & 0.2174 & 0.0007 \\
\hline $\begin{array}{l}\text { Northeast } \\
\text { U.S. }\end{array}$ & $\begin{array}{l}\text { Alosa } \\
\text { pseudoharengus }\end{array}$ & Alewife & 47 & 3.51 & 0.0694 & 0.0036 \\
\hline $\begin{array}{l}\text { Northeast } \\
\text { U.S. }\end{array}$ & Alosa sapidissma & American shad & 47 & 3.19 & 0.3913 & 0.0004 \\
\hline $\begin{array}{l}\text { Northeast } \\
\text { U.S. }\end{array}$ & Amblyraja radiata & Starry ray & 47 & 4.00 & -0.7872 & 0.0110 \\
\hline $\begin{array}{l}\text { Northeast } \\
\text { U.S. }\end{array}$ & Ammodytes dubius & Northern sand lance & 47 & 3.10 & 0.0102 & 0.0008 \\
\hline $\begin{array}{l}\text { Northeast } \\
\text { U.S. }\end{array}$ & Anarhichas lupus & Atlantic wolffish & 47 & 3.24 & -0.6540 & 0.0018 \\
\hline $\begin{array}{l}\text { Northeast } \\
\text { U.S. }\end{array}$ & Anchoa hepsetus & $\begin{array}{l}\text { Broad-striped } \\
\text { anchovy }\end{array}$ & 47 & 3.33 & 0.3521 & 0.0012 \\
\hline $\begin{array}{l}\text { Northeast } \\
\text { U.S. }\end{array}$ & Anchoa mitchilli & Bay anchovy & 47 & 3.46 & 0.3354 & 0.0010 \\
\hline $\begin{array}{l}\text { Northeast } \\
\text { U.S. }\end{array}$ & Antimora rostrata & Blue antimora & 47 & 3.58 & 0.1700 & * \\
\hline $\begin{array}{l}\text { Northeast } \\
\text { U.S. }\end{array}$ & Arctica islandica & Ocean quahog & 47 & 2.00 & 0.0811 & * \\
\hline $\begin{array}{l}\text { Northeast } \\
\text { U.S. }\end{array}$ & Argentina silus & Greater argentine & 47 & 3.31 & -0.4024 & 0.0006 \\
\hline $\begin{array}{l}\text { Northeast } \\
\text { U.S. }\end{array}$ & $\begin{array}{l}\text { Aspidophoroides } \\
\text { monopterygius }\end{array}$ & Alligatorfish & 47 & 3.00 & 0.1230 & $*$ \\
\hline $\begin{array}{l}\text { Northeast } \\
\text { U.S. }\end{array}$ & $\begin{array}{l}\text { Bairdiella } \\
\text { chrysoura }\end{array}$ & Silver perch & 47 & 3.20 & 0.3950 & 0.0001 \\
\hline $\begin{array}{l}\text { Northeast } \\
\text { U.S. }\end{array}$ & $\begin{array}{l}\text { Brevoortia } \\
\text { tyrannus }\end{array}$ & Atlantic menhaden & 47 & 2.25 & 0.3355 & 0.0002 \\
\hline $\begin{array}{l}\text { Northeast } \\
\text { U.S. }\end{array}$ & Brosme brosme & Tusk & 47 & 4.00 & -0.6559 & 0.0028 \\
\hline $\begin{array}{l}\text { Northeast } \\
\text { U.S. }\end{array}$ & Cancer borealis & Jonah crab & 47 & 2.60 & 0.4695 & 0.0004 \\
\hline $\begin{array}{l}\text { Northeast } \\
\text { U.S. }\end{array}$ & Cancer irroratus & Atlantic rock crab & 47 & 2.60 & 0.1900 & 0.0003 \\
\hline $\begin{array}{l}\text { Northeast } \\
\text { U.S. }\end{array}$ & $\begin{array}{l}\text { Carcharhinus } \\
\text { obscurus }\end{array}$ & Dusky shark & 47 & 4.49 & -0.2601 & 0.0003 \\
\hline $\begin{array}{l}\text { Northeast } \\
\text { U.S. }\end{array}$ & $\begin{array}{l}\text { Carcharhinus } \\
\text { plumbeus }\end{array}$ & Sandbar shark & 47 & 4.49 & 0.2465 & 0.0008 \\
\hline $\begin{array}{l}\text { Northeast } \\
\text { U.S. }\end{array}$ & Carcharias taurus & Sand tiger shark & 47 & 4.50 & 0.1613 & 0.0008 \\
\hline $\begin{array}{l}\text { Northeast } \\
\text { U.S. }\end{array}$ & Caranx crysos & Blue runner & 47 & 4.40 & 0.5278 & $*$ \\
\hline $\begin{array}{l}\text { Northeast } \\
\text { U.S. }\end{array}$ & Centropristis striata & Black seabass & 47 & 3.98 & 0.3321 & 0.0012 \\
\hline $\begin{array}{l}\text { Northeast } \\
\text { U.S. }\end{array}$ & $\begin{array}{l}\text { Centroscyllium } \\
\text { fabricii }\end{array}$ & Black dogfish & 47 & 3.90 & 0.0424 & * \\
\hline $\begin{array}{l}\text { Northeast } \\
\text { U.S. }\end{array}$ & Cephalopoda & Cephalopods & 47 & 3.81 & -0.4685 & 0.0003 \\
\hline $\begin{array}{l}\text { Northeast } \\
\text { U.S. }\end{array}$ & $\begin{array}{l}\text { Cetorhinus } \\
\text { maximus }\end{array}$ & Basking shark & 47 & 3.20 & 0.0351 & 0.0006 \\
\hline $\begin{array}{l}\text { Northeast } \\
\text { U.S. }\end{array}$ & $\begin{array}{l}\text { Chionoecetes } \\
\text { opilio }\end{array}$ & Queen crab & 47 & 2.30 & 0.1914 & $*$ \\
\hline $\begin{array}{l}\text { Northeast } \\
\text { U.S. }\end{array}$ & $\begin{array}{l}\text { Citharichthys } \\
\text { arctifrons }\end{array}$ & $\begin{array}{l}\text { Gulf Stream } \\
\text { flounder }\end{array}$ & 47 & 3.30 & 0.5541 & 0.0003 \\
\hline Northeast & Clupea harengus & Atlantic herring & 47 & 3.23 & 0.5430 & 0.0135 \\
\hline
\end{tabular}




\begin{tabular}{|c|c|c|c|c|c|c|}
\hline U.S. & & & & & & \\
\hline $\begin{array}{l}\text { Northeast } \\
\text { U.S. }\end{array}$ & $\begin{array}{l}\text { Coelorhynchus } \\
\text { carminatus }\end{array}$ & $\begin{array}{l}\text { Hollowsnout } \\
\text { grenadier }\end{array}$ & 47 & 3.60 & -0.1689 & $*$ \\
\hline $\begin{array}{l}\text { Northeast } \\
\text { U.S. }\end{array}$ & Conger oceanicus & American conger & 47 & 4.50 & -0.2050 & 0.0001 \\
\hline $\begin{array}{l}\text { Northeast } \\
\text { U.S. }\end{array}$ & $\begin{array}{l}\text { Cyclopterus } \\
\text { lumpus }\end{array}$ & Lumpsucker & 47 & 3.89 & 0.1323 & 0.0002 \\
\hline $\begin{array}{l}\text { Northeast } \\
\text { U.S. }\end{array}$ & Cynoscion regalis & Gray weakfish & 47 & 3.77 & 0.3497 & 0.0025 \\
\hline $\begin{array}{l}\text { Northeast } \\
\text { U.S. }\end{array}$ & Dasyatis americana & Southern stingray & 47 & 3.50 & 0.0814 & 0.0019 \\
\hline $\begin{array}{l}\text { Northeast } \\
\text { U.S. }\end{array}$ & Dasyatis centroura & Roughtail stingray & 47 & 3.81 & 0.1565 & 0.0076 \\
\hline $\begin{array}{l}\text { Northeast } \\
\text { U.S. }\end{array}$ & Dasyatis say & Bluntnose stingray & 47 & 3.50 & 0.0727 & 0.0040 \\
\hline $\begin{array}{l}\text { Northeast } \\
\text { U.S. }\end{array}$ & $\begin{array}{l}\text { Dibranchus } \\
\text { atlanticus }\end{array}$ & Atlantic batfish & 47 & 3.40 & 0.1186 & * \\
\hline $\begin{array}{l}\text { Northeast } \\
\text { U.S. }\end{array}$ & Dipturus laevis & Barndoor skate & 47 & 3.50 & 0.3038 & 0.0031 \\
\hline $\begin{array}{l}\text { Northeast } \\
\text { U.S. }\end{array}$ & $\begin{array}{l}\text { Enchelyopus } \\
\text { cimbrius }\end{array}$ & Fourbeard rockling & 47 & 3.53 & 0.1156 & 0.0001 \\
\hline $\begin{array}{l}\text { Northeast } \\
\text { U.S. }\end{array}$ & $\begin{array}{l}\text { Etropus } \\
\text { micorostomus }\end{array}$ & $\begin{array}{l}\text { Smallmouth } \\
\text { flounder }\end{array}$ & 47 & 3.30 & 0.5768 & $*$ \\
\hline $\begin{array}{l}\text { Northeast } \\
\text { U.S. }\end{array}$ & Etrumeus teres & $\begin{array}{l}\text { Red-eye round } \\
\text { herring }\end{array}$ & 47 & 3.49 & 0.2073 & 0.0030 \\
\hline $\begin{array}{l}\text { Northeast } \\
\text { U.S. }\end{array}$ & Gadus morhua & Atlantic cod & 47 & 4.42 & -0.6059 & 0.0426 \\
\hline $\begin{array}{l}\text { Northeast } \\
\text { U.S. }\end{array}$ & $\begin{array}{l}\text { Geryon } \\
\text { quinquedens }\end{array}$ & Red deepsea crab & 47 & 2.30 & 0.4241 & 0.0001 \\
\hline $\begin{array}{l}\text { Northeast } \\
\text { U.S. }\end{array}$ & $\begin{array}{l}\text { Glyptocephus } \\
\text { cynoglossus }\end{array}$ & Witch flounder & 47 & 3.14 & -0.4061 & 0.0043 \\
\hline $\begin{array}{l}\text { Northeast } \\
\text { U.S. }\end{array}$ & $\begin{array}{l}\text { Helicolenus } \\
\text { dactylopterus }\end{array}$ & Blackbelly rosefish & 47 & 3.81 & 0.6133 & 0.0005 \\
\hline $\begin{array}{l}\text { Northeast } \\
\text { U.S. }\end{array}$ & $\begin{array}{l}\text { Hemitripterus } \\
\text { americanus }\end{array}$ & Sea raven & 47 & 4.50 & 0.5301 & 0.0037 \\
\hline $\begin{array}{l}\text { Northeast } \\
\text { U.S. }\end{array}$ & $\begin{array}{l}\text { Hippoglossoides } \\
\text { platessoides }\end{array}$ & American plaice & 47 & 3.65 & -0.3636 & 0.0086 \\
\hline $\begin{array}{l}\text { Northeast } \\
\text { U.S. }\end{array}$ & $\begin{array}{l}\text { Hippoglossus } \\
\text { hippoglossus }\end{array}$ & Atlantic halibut & 47 & 4.53 & -0.1138 & 0.0008 \\
\hline $\begin{array}{l}\text { Northeast } \\
\text { U.S. }\end{array}$ & Illex illecebrosus & $\begin{array}{l}\text { Northern shortfin } \\
\text { squid }\end{array}$ & 47 & 3.98 & 0.1175 & 0.0048 \\
\hline $\begin{array}{l}\text { Northeast } \\
\text { U.S. }\end{array}$ & $\begin{array}{l}\text { Leiostomus } \\
\text { xanthurus }\end{array}$ & Spot croaker & 47 & 3.94 & 0.4223 & 0.0032 \\
\hline $\begin{array}{l}\text { Northeast } \\
\text { U.S. }\end{array}$ & $\begin{array}{l}\text { Lepophidium } \\
\text { profundorum }\end{array}$ & Blackrim cusk-eel & 47 & 3.40 & 0.3099 & 0.0001 \\
\hline $\begin{array}{l}\text { Northeast } \\
\text { U.S. }\end{array}$ & Leucoraja erinacea & Little skate & 47 & 3.40 & 0.6152 & 0.0460 \\
\hline $\begin{array}{l}\text { Northeast } \\
\text { U.S. }\end{array}$ & Leucoraja garmani & Rosette skate & 47 & 3.60 & 0.5523 & 0.0002 \\
\hline $\begin{array}{l}\text { Northeast } \\
\text { U.S. }\end{array}$ & Leucoraja ocellata & Winter skate & 47 & 4.40 & 0.4376 & 0.0402 \\
\hline $\begin{array}{l}\text { Northeast } \\
\text { U.S. }\end{array}$ & Limanda ferruginea & Yellowtail flounder & 47 & 3.22 & -0.1156 & 0.0131 \\
\hline $\begin{array}{l}\text { Northeast } \\
\text { U.S. }\end{array}$ & Doryteuthis pealeii & $\begin{array}{l}\text { Longfin inshore } \\
\text { squid }\end{array}$ & 47 & 3.51 & 0.2784 & 0.0186 \\
\hline
\end{tabular}




\begin{tabular}{|c|c|c|c|c|c|c|c|}
\hline $\begin{array}{l}\text { Northeast } \\
\text { U.S. }\end{array}$ & $\begin{array}{l}\text { Lophius } \\
\text { americanus }\end{array}$ & American angler & 47 & 4.49 & -0.1082 & & 0.0108 \\
\hline $\begin{array}{l}\text { Northeast } \\
\text { U.S. }\end{array}$ & $\begin{array}{l}\text { Lopholatilus } \\
\text { chamaeleonticeps }\end{array}$ & $\begin{array}{l}\text { Great northern } \\
\text { tilefish }\end{array}$ & 47 & 3.45 & -0.0697 & & 0.0001 \\
\hline $\begin{array}{l}\text { Northeast } \\
\text { U.S. }\end{array}$ & $\begin{array}{l}\text { Lumpenus } \\
\text { lumpretaeformis }\end{array}$ & Snakeblenny & 47 & 3.60 & 0.2285 & $*$ & \\
\hline $\begin{array}{l}\text { Northeast } \\
\text { U.S. }\end{array}$ & $\begin{array}{l}\text { Macrorhamphosus } \\
\text { scolopax }\end{array}$ & Longspine snipefish & 47 & 3.47 & 0.4360 & $*$ & \\
\hline $\begin{array}{l}\text { Northeast } \\
\text { U.S. }\end{array}$ & Macrourus berglax & $\begin{array}{l}\text { Onion-eye } \\
\text { grenadier }\end{array}$ & 47 & 3.62 & -0.1148 & * & \\
\hline $\begin{array}{l}\text { Northeast } \\
\text { U.S. }\end{array}$ & $\begin{array}{l}\text { Zoarces } \\
\text { americanus }\end{array}$ & Ocean pout & 47 & 3.42 & -0.0083 & & 0.0081 \\
\hline $\begin{array}{l}\text { Northeast } \\
\text { U.S. }\end{array}$ & Malacoraja senta & Smooth skate & 47 & 3.50 & -0.1637 & & 0.0012 \\
\hline $\begin{array}{l}\text { Northeast } \\
\text { U.S. }\end{array}$ & Mallotus villosus & Capelin & 47 & 3.15 & -0.1847 & $*$ & \\
\hline $\begin{array}{l}\text { Northeast } \\
\text { U.S. }\end{array}$ & $\begin{array}{l}\text { Melanogrammus } \\
\text { aeglefinus }\end{array}$ & Haddock & 47 & 4.09 & -0.2100 & & 0.0631 \\
\hline $\begin{array}{l}\text { Northeast } \\
\text { U.S. }\end{array}$ & Menidia menidia & Atlantic silverside & 47 & 3.18 & 0.4109 & $*$ & \\
\hline $\begin{array}{l}\text { Northeast } \\
\text { U.S. }\end{array}$ & $\begin{array}{l}\text { Menticirrhus } \\
\text { saxatilis }\end{array}$ & $\begin{array}{l}\text { Northern } \\
\text { kingcroaker }\end{array}$ & 47 & 3.58 & 0.3140 & $*$ & \\
\hline $\begin{array}{l}\text { Northeast } \\
\text { U.S. }\end{array}$ & Merluccius albidus & Offshore silver hake & 47 & 3.40 & 0.0231 & & 0.0002 \\
\hline $\begin{array}{l}\text { Northeast } \\
\text { U.S. }\end{array}$ & $\begin{array}{l}\text { Merluccius } \\
\text { bilinearis }\end{array}$ & Silver hake & 47 & 4.26 & 0.1637 & & 0.0219 \\
\hline $\begin{array}{l}\text { Northeast } \\
\text { U.S. }\end{array}$ & $\begin{array}{l}\text { Micropogonias } \\
\text { undulatus }\end{array}$ & Atlantic croaker & 47 & 3.31 & 0.5408 & & 0.0107 \\
\hline $\begin{array}{l}\text { Northeast } \\
\text { U.S. }\end{array}$ & Morone americana & White perch & 47 & 3.08 & -0.1094 & * & \\
\hline $\begin{array}{l}\text { Northeast } \\
\text { U.S. }\end{array}$ & Morone saxatilis & Striped sea-bass & 47 & 4.34 & 0.7608 & & 0.0013 \\
\hline $\begin{array}{l}\text { Northeast } \\
\text { U.S. }\end{array}$ & Mustelus canis & $\begin{array}{l}\text { Dusky smooth- } \\
\text { hound }\end{array}$ & 47 & 3.70 & 0.3887 & & 0.0142 \\
\hline $\begin{array}{l}\text { Northeast } \\
\text { U.S. }\end{array}$ & $\begin{array}{l}\text { Myliobatis } \\
\text { freminvillei }\end{array}$ & Bullnose eagle ray & 47 & 3.20 & 0.4536 & & 0.0024 \\
\hline $\begin{array}{l}\text { Northeast } \\
\text { U.S. }\end{array}$ & $\begin{array}{l}\text { Myoxocephalus } \\
\text { aenaeus }\end{array}$ & Grubby & 47 & 3.70 & 0.3531 & $*$ & \\
\hline $\begin{array}{l}\text { Northeast } \\
\text { U.S. }\end{array}$ & $\begin{array}{l}\text { Myoxocephalus } \\
\text { octodecemspinosus }\end{array}$ & Longhorn sculpin & 47 & 3.50 & 0.2248 & & 0.0084 \\
\hline $\begin{array}{l}\text { Northeast } \\
\text { U.S. }\end{array}$ & $\begin{array}{l}\text { Myoxocephalus } \\
\text { scorpius }\end{array}$ & Shorthorn sculpin & 47 & 3.90 & 0.0315 & * & \\
\hline $\begin{array}{l}\text { Northeast } \\
\text { U.S. }\end{array}$ & Myxine glutinosa & Hagfish & 47 & 3.45 & 0.0213 & $*$ & \\
\hline $\begin{array}{l}\text { Northeast } \\
\text { U.S. }\end{array}$ & Nezumia bairdii & $\begin{array}{l}\text { Marlin-spike } \\
\text { grenadier }\end{array}$ & 47 & 3.60 & -0.4215 & $*$ & \\
\hline $\begin{array}{l}\text { Northeast } \\
\text { U.S. }\end{array}$ & $\begin{array}{l}\text { Ophichthus } \\
\text { cruentifer }\end{array}$ & Margined snake eel & 47 & 3.40 & -0.1247 & * & \\
\hline $\begin{array}{l}\text { Northeast } \\
\text { U.S. }\end{array}$ & $\begin{array}{l}\text { Ophidion } \\
\text { marginatum }\end{array}$ & Striped cusk-eel & 47 & 3.50 & -0.0130 & $*$ & \\
\hline $\begin{array}{l}\text { Northeast } \\
\text { U.S. }\end{array}$ & Opsanus tau & Oyster toadfish & 47 & 3.60 & 0.0099 & $*$ & \\
\hline $\begin{array}{l}\text { Northeast } \\
\text { U.S. }\end{array}$ & Osmerus mordax & Rainbow smelt & 47 & 3.00 & 0.2463 & * & \\
\hline Northeast & Pandalus borealis & Northern prawn & 47 & 2.46 & 0.6218 & * & \\
\hline
\end{tabular}




\begin{tabular}{|c|c|c|c|c|c|c|}
\hline U.S. & & & & & & \\
\hline $\begin{array}{l}\text { Northeast } \\
\text { U.S. }\end{array}$ & $\begin{array}{l}\text { Paralichthys } \\
\text { dentatus }\end{array}$ & Summer flounder & 47 & 4.49 & 0.5560 & 0.0067 \\
\hline $\begin{array}{l}\text { Northeast } \\
\text { U.S. }\end{array}$ & $\begin{array}{l}\text { Hippoglossina } \\
\text { oblonga }\end{array}$ & $\begin{array}{l}\text { American fourspot } \\
\text { flounder }\end{array}$ & 47 & 4.20 & 0.6596 & 0.0056 \\
\hline $\begin{array}{l}\text { Northeast } \\
\text { U.S. }\end{array}$ & $\begin{array}{l}\text { Peprilus } \\
\text { triancanthus }\end{array}$ & American butterfish & 47 & 3.97 & 0.1045 & 0.0148 \\
\hline $\begin{array}{l}\text { Northeast } \\
\text { U.S. }\end{array}$ & $\begin{array}{l}\text { Peristedion } \\
\text { miniatum }\end{array}$ & Armored searobin & 47 & 3.70 & 0.1693 & 0.0001 \\
\hline $\begin{array}{l}\text { Northeast } \\
\text { U.S. }\end{array}$ & $\begin{array}{l}\text { Petromyzon } \\
\text { marinus }\end{array}$ & Sea lamprey & 47 & 4.37 & 0.3702 & $*$ \\
\hline $\begin{array}{l}\text { Northeast } \\
\text { U.S. }\end{array}$ & $\begin{array}{l}\text { Placopecten } \\
\text { magellanicus }\end{array}$ & $\begin{array}{l}\text { American sea } \\
\text { scallop }\end{array}$ & 47 & 2.00 & 0.4579 & 0.0094 \\
\hline $\begin{array}{l}\text { Northeast } \\
\text { U.S. }\end{array}$ & Pogonias cromis & Black drum & 47 & 3.89 & 0.1709 & $*$ \\
\hline $\begin{array}{l}\text { Northeast } \\
\text { U.S. }\end{array}$ & Pollachius virens & Saithe & 47 & 4.38 & -0.4801 & 0.0251 \\
\hline $\begin{array}{l}\text { Northeast } \\
\text { U.S. }\end{array}$ & $\begin{array}{l}\text { Pomatomus } \\
\text { saltatrix }\end{array}$ & Bluefish & 47 & 4.50 & 0.1212 & 0.0022 \\
\hline $\begin{array}{l}\text { Northeast } \\
\text { U.S. }\end{array}$ & $\begin{array}{l}\text { Priacanthus } \\
\text { arenatus }\end{array}$ & Atlantic bigeye & 47 & 4.00 & 0.1228 & $*$ \\
\hline $\begin{array}{l}\text { Northeast } \\
\text { U.S. }\end{array}$ & Prionotus carolinus & Northern searobin & 47 & 4.10 & 0.0509 & 0.0085 \\
\hline $\begin{array}{l}\text { Northeast } \\
\text { U.S. }\end{array}$ & Prionotus evolans & Striped searobin & 47 & 4.30 & 0.4487 & 0.0007 \\
\hline $\begin{array}{l}\text { Northeast } \\
\text { U.S. }\end{array}$ & $\begin{array}{l}\text { Pseudopleuronectes } \\
\text { americanus }\end{array}$ & Winter flounder & 47 & 2.83 & -0.0157 & 0.0091 \\
\hline $\begin{array}{l}\text { Northeast } \\
\text { U.S. }\end{array}$ & Raja eglanteria & Clearnose skate & 47 & 3.70 & 0.6330 & 0.0051 \\
\hline $\begin{array}{l}\text { Northeast } \\
\text { U.S. }\end{array}$ & $\begin{array}{l}\text { Reinhardtius } \\
\text { hippoglossoides }\end{array}$ & Greenland halibut & 47 & 4.48 & 0.4343 & * \\
\hline $\begin{array}{l}\text { Northeast } \\
\text { U.S. }\end{array}$ & Sarda sarda & Atlantic bonito & 47 & 4.20 & 0.0833 & $*$ \\
\hline $\begin{array}{l}\text { Northeast } \\
\text { U.S. }\end{array}$ & Scomber japonicus & Chub mackerel & 47 & 3.09 & 0.1098 & 0.0002 \\
\hline $\begin{array}{l}\text { Northeast } \\
\text { U.S. }\end{array}$ & Scomber scombrus & Atlantic mackerel & 47 & 3.18 & 0.5430 & 0.0118 \\
\hline $\begin{array}{l}\text { Northeast } \\
\text { U.S. }\end{array}$ & $\begin{array}{l}\text { Scophthalmus } \\
\text { aquosus }\end{array}$ & Windowpane & 47 & 3.55 & 0.0398 & 0.0055 \\
\hline $\begin{array}{l}\text { Northeast } \\
\text { U.S. }\end{array}$ & Scyliorhinus retifer & Chain catshark & 47 & 4.40 & 0.6707 & 0.0001 \\
\hline $\begin{array}{l}\text { Northeast } \\
\text { U.S. }\end{array}$ & Sebastes fasciatus & Acadian redfish & 47 & 3.20 & 0.0324 & 0.0558 \\
\hline $\begin{array}{l}\text { Northeast } \\
\text { U.S. }\end{array}$ & Selene setapinnis & Atlantic moonfish & 47 & 3.72 & 0.4337 & $*$ \\
\hline $\begin{array}{l}\text { Northeast } \\
\text { U.S. }\end{array}$ & Selene vomer & Lookdown & 47 & 4.30 & 0.1947 & * \\
\hline $\begin{array}{l}\text { Northeast } \\
\text { U.S. }\end{array}$ & Spisula solidissima & Atlantic surf clam & 47 & 2.00 & 0.0072 & $*$ \\
\hline $\begin{array}{l}\text { Northeast } \\
\text { U.S. }\end{array}$ & Squalus acanthias & Piked dogfish & 47 & 4.30 & 0.6078 & 0.3999 \\
\hline $\begin{array}{l}\text { Northeast } \\
\text { U.S. }\end{array}$ & Squatina dumeril & Sand devil & 47 & 4.50 & -0.0148 & 0.0008 \\
\hline $\begin{array}{l}\text { Northeast } \\
\text { U.S. }\end{array}$ & $\begin{array}{l}\text { Stenotomus } \\
\text { chyrsops }\end{array}$ & Scup & 47 & 3.90 & 0.2969 & 0.0074 \\
\hline
\end{tabular}




\begin{tabular}{|c|c|c|c|c|c|c|}
\hline $\begin{array}{l}\text { Northeast } \\
\text { U.S. }\end{array}$ & Synagrops bellus & Blackmouth bass & 47 & 3.70 & 0.4031 & $*$ \\
\hline $\begin{array}{l}\text { Northeast } \\
\text { U.S. }\end{array}$ & Syngnathus fuscus & Northern pipefish & 47 & 3.20 & 0.2928 & $*$ \\
\hline $\begin{array}{l}\text { Northeast } \\
\text { U.S. }\end{array}$ & Tautoga onitis & Tautog & 47 & 3.33 & 0.0762 & * \\
\hline $\begin{array}{l}\text { Northeast } \\
\text { U.S. }\end{array}$ & $\begin{array}{l}\text { Tautogolabrus } \\
\text { adspersus }\end{array}$ & Cunner & 47 & 3.54 & 0.1397 & 0.0003 \\
\hline $\begin{array}{l}\text { Northeast } \\
\text { U.S. }\end{array}$ & Torpedo nobiliana & Electric ray & 47 & 4.50 & 0.0939 & 0.0004 \\
\hline $\begin{array}{l}\text { Northeast } \\
\text { U.S. }\end{array}$ & Trichiurus lepturus & Largehead hairtail & 47 & 4.45 & 0.2514 & * \\
\hline $\begin{array}{l}\text { Northeast } \\
\text { U.S. }\end{array}$ & Triglops murrayi & Moustache sculpin & 47 & 3.50 & -0.5097 & * \\
\hline $\begin{array}{l}\text { Northeast } \\
\text { U.S. }\end{array}$ & Phycis chesteri & Longfin hake & 47 & 3.20 & -0.4727 & 0.0001 \\
\hline $\begin{array}{l}\text { Northeast } \\
\text { U.S. }\end{array}$ & Urophycis regia & Red hake & 47 & 3.60 & 0.5282 & 0.0031 \\
\hline $\begin{array}{l}\text { Northeast } \\
\text { U.S. }\end{array}$ & Urophycis tenuis & White hake & 47 & 4.20 & -0.2766 & 0.0195 \\
\hline $\begin{array}{l}\text { Northeast } \\
\text { U.S. }\end{array}$ & Urophycis chuss & Red hake & 47 & 3.60 & -0.1822 & 0.0133 \\
\hline $\begin{array}{l}\text { Northeast } \\
\text { U.S. }\end{array}$ & $\begin{array}{l}\text { Zenopsis } \\
\text { conchifera }\end{array}$ & Silvery John dory & 47 & 4.50 & 0.6441 & 0.0002 \\
\hline North Sea & $\begin{array}{l}\text { Ammodytes } \\
\text { tobianus }\end{array}$ & Small sandeel & 28 & 3.10 & 0.2114 & 0.0001 \\
\hline North Sea & Anarhichas lupus & Atlantic wolffish & 28 & 3.24 & -0.7143 & 0.0007 \\
\hline North Sea & $\begin{array}{l}\text { Chelidonichthys } \\
\text { cuculus }\end{array}$ & Red gurnard & 28 & 3.85 & 0.6331 & 0.0002 \\
\hline North Sea & Clupea harengus & Atlantic herring & 28 & 3.23 & 0.1217 & 0.2581 \\
\hline North Sea & $\begin{array}{l}\text { Dicentrarchus } \\
\text { labrax }\end{array}$ & European seabass & 28 & 3.80 & 0.6295 & * \\
\hline North Sea & Eutrigla gurnardus & Grey gurnard & 28 & 3.57 & 0.7037 & 0.0305 \\
\hline North Sea & Gadus morhua & Atlantic cod & 28 & 4.42 & -0.7249 & 0.0439 \\
\hline North Sea & $\begin{array}{l}\text { Glyptocephalus } \\
\text { cynoglossus }\end{array}$ & Witch flounder & 28 & 3.14 & -0.3333 & 0.0006 \\
\hline North Sea & $\begin{array}{l}\text { Hippoglossus } \\
\text { hippoglossus }\end{array}$ & Atlantic halibut & 28 & 4.53 & 0.3545 & * \\
\hline North Sea & $\begin{array}{l}\text { Lepidorhombus } \\
\text { whiffiagonis }\end{array}$ & Megrim & 28 & 3.58 & 0.0899 & 0.0005 \\
\hline North Sea & Limanda limanda & Common dab & 28 & 3.29 & 0.3333 & 0.0598 \\
\hline North Sea & Lophius piscatorius & Angler & 28 & 4.49 & -0.0106 & 0.0025 \\
\hline North Sea & $\begin{array}{l}\text { Melanogrammus } \\
\text { aeglefinus }\end{array}$ & Haddock & 28 & 4.09 & -0.0635 & 0.2509 \\
\hline North Sea & $\begin{array}{l}\text { Merlangius } \\
\text { merlangus }\end{array}$ & Whiting & 28 & 4.29 & -0.2804 & 0.1835 \\
\hline North Sea & $\begin{array}{l}\text { Merluccius } \\
\text { merluccius }\end{array}$ & European hake & 28 & 4.42 & 0.2381 & 0.0006 \\
\hline North Sea & $\begin{array}{l}\text { Micromesistius } \\
\text { poutassou }\end{array}$ & Blue whiting & 28 & 4.01 & 0.2381 & 0.0001 \\
\hline North Sea & Microstomus kitt & Lemon sole & 28 & 3.22 & -0.0899 & 0.0033 \\
\hline North Sea & Mullus surmuletus & Surmullet & 28 & 3.35 & 0.7698 & * \\
\hline North Sea & Platichthys flesus & European flounder & 28 & 3.53 & -0.2116 & 0.0008 \\
\hline North Sea & Pleuronectes & European plaice & 28 & 3.26 & 0.0106 & 0.0097 \\
\hline
\end{tabular}




\begin{tabular}{|c|c|c|c|c|c|c|}
\hline & platessa & & & & & \\
\hline North Sea & Pollachius virens & Saithe & 28 & 4.38 & 0.2275 & 0.0316 \\
\hline North Sea & Psetta maxima & Turbot & 28 & 3.05 & 0.1534 & 0.0003 \\
\hline North Sea & Scomber scombrus & Atlantic mackerel & 28 & 3.18 & 0.4550 & 0.0237 \\
\hline North Sea & $\begin{array}{l}\text { Scophthalmus } \\
\text { rhombus }\end{array}$ & Brill & 28 & 3.79 & 0.1852 & 0.0001 \\
\hline North Sea & Solea solea & Common sole & 28 & 3.17 & 0.2011 & 0.0001 \\
\hline North Sea & Sprattus sprattus & European sprat & 28 & 3.00 & 0.5079 & 0.0179 \\
\hline North Sea & $\begin{array}{l}\text { Trachurus } \\
\text { trachurus }\end{array}$ & $\begin{array}{l}\text { Atlantic horse } \\
\text { mackerel }\end{array}$ & 28 & 3.64 & 0.5344 & 0.0015 \\
\hline North Sea & $\begin{array}{l}\text { Chelidonichthys } \\
\text { lucerna }\end{array}$ & Tub gurnard & 28 & 3.65 & 0.1201 & $*$ \\
\hline North Sea & $\begin{array}{l}\text { Trisopterus } \\
\text { esmarkii }\end{array}$ & Norway pout & 28 & 3.22 & 0.0899 & 0.0789 \\
\hline North Sea & Zeus faber & John dory & 28 & 4.50 & 0.6113 & * \\
\hline $\begin{array}{l}\text { Portuguese } \\
\text { coast }\end{array}$ & Boops boops & Bogue & 26 & 3.00 & 0.0954 & 0.0103 \\
\hline $\begin{array}{l}\text { Portuguese } \\
\text { coast }\end{array}$ & Conger conger & European conger & 26 & 4.29 & 0.0215 & 0.0030 \\
\hline $\begin{array}{l}\text { Portuguese } \\
\text { coast }\end{array}$ & $\begin{array}{l}\text { Lepidopus } \\
\text { caudatus }\end{array}$ & Silver scabbardfish & 26 & 3.85 & 0.2677 & 0.0099 \\
\hline $\begin{array}{l}\text { Portuguese } \\
\text { coast }\end{array}$ & $\begin{array}{l}\text { Merluccius } \\
\text { merluccius }\end{array}$ & European hake & 26 & 4.42 & 0.5200 & 0.0888 \\
\hline $\begin{array}{l}\text { Portuguese } \\
\text { coast }\end{array}$ & $\begin{array}{l}\text { Micromesistius } \\
\text { poutassou }\end{array}$ & Blue whiting & 26 & 4.01 & -0.2062 & 0.6298 \\
\hline $\begin{array}{l}\text { Portuguese } \\
\text { coast }\end{array}$ & Pagellus acarne & Axillary seabream & 26 & 3.48 & 0.2369 & 0.0348 \\
\hline $\begin{array}{l}\text { Portuguese } \\
\text { coast }\end{array}$ & Scomber scombrus & Atlantic mackerel & 26 & 3.18 & 0.3108 & 0.0859 \\
\hline $\begin{array}{l}\text { Portuguese } \\
\text { coast }\end{array}$ & $\begin{array}{l}\text { Trachurus } \\
\text { trachurus }\end{array}$ & $\begin{array}{l}\text { Atlantic horse } \\
\text { mackerel }\end{array}$ & 26 & 3.64 & 0.0215 & 0.1202 \\
\hline $\begin{array}{l}\text { Portuguese } \\
\text { coast }\end{array}$ & Trisopterus luscus & Pouting & 26 & 3.73 & -0.0954 & 0.0109 \\
\hline $\begin{array}{l}\text { Portuguese } \\
\text { coast }\end{array}$ & Zeus faber & John dory & 26 & 4.50 & 0.1323 & 0.0064 \\
\hline $\begin{array}{l}\text { Southern } \\
\text { Benguela }\end{array}$ & $\begin{array}{l}\text { Argyrosomus } \\
\text { hololepidotus }\end{array}$ & Southern meagre & 23 & 3.82 & -0.3050 & 0.0002 \\
\hline $\begin{array}{l}\text { Southern } \\
\text { Benguela } \\
\end{array}$ & $\begin{array}{l}\text { Argyrozona } \\
\text { argyrozona }\end{array}$ & Carpenter seabream & 23 & 3.05 & -0.2164 & 0.0004 \\
\hline $\begin{array}{l}\text { Southern } \\
\text { Benguela }\end{array}$ & $\begin{array}{l}\text { Arnoglossus } \\
\text { capensis }\end{array}$ & Cape scaldfish & 23 & 3.60 & -0.0409 & $*$ \\
\hline $\begin{array}{l}\text { Southern } \\
\text { Benguela }\end{array}$ & $\begin{array}{l}\text { Austroglossus } \\
\text { microlepis }\end{array}$ & West coast sole & 23 & 3.48 & -0.1111 & 0.0001 \\
\hline $\begin{array}{l}\text { Southern } \\
\text { Benguela }\end{array}$ & $\begin{array}{l}\text { Austroglossus } \\
\text { pectoralis }\end{array}$ & Mud sole & 23 & 4.03 & -0.0526 & 0.0007 \\
\hline $\begin{array}{l}\text { Southern } \\
\text { Benguela }\end{array}$ & Brama brama & Atlantic pomfret & 23 & 4.08 & 0.3333 & 0.0006 \\
\hline $\begin{array}{l}\text { Southern } \\
\text { Benguela }\end{array}$ & $\begin{array}{l}\text { Callorhinchus } \\
\text { capensis }\end{array}$ & Cape elephantfish & 23 & 3.45 & 0.2281 & 0.0070 \\
\hline $\begin{array}{l}\text { Southern } \\
\text { Benguela }\end{array}$ & $\begin{array}{l}\text { Chelidonichthys } \\
\text { capensis }\end{array}$ & Cape gurnard & 23 & 4.21 & 0.4503 & 0.0057 \\
\hline $\begin{array}{l}\text { Southern } \\
\text { Benguela }\end{array}$ & $\begin{array}{l}\text { Chelidonichthys } \\
\text { queketti }\end{array}$ & Lesser gurnard & 23 & 3.90 & -0.1579 & 0.0123 \\
\hline Southern & Chirodactylus & Bank steenbras & 23 & 3.30 & -0.1345 & 0.0001 \\
\hline
\end{tabular}




\begin{tabular}{|c|c|c|c|c|c|c|}
\hline Benguela & grandis & & & & & \\
\hline $\begin{array}{l}\text { Southern } \\
\text { Benguela }\end{array}$ & $\begin{array}{l}\text { Congiopodus } \\
\text { spinifer }\end{array}$ & Spinenose horsefish & 23 & 3.30 & -0.1813 & 0.0005 \\
\hline $\begin{array}{l}\text { Southern } \\
\text { Benguela }\end{array}$ & $\begin{array}{l}\text { Congiopodus } \\
\text { torvus }\end{array}$ & Smooth horsefish & 23 & 3.40 & -0.0526 & 0.0004 \\
\hline $\begin{array}{l}\text { Southern } \\
\text { Benguela }\end{array}$ & $\begin{array}{l}\text { Cynoglossus } \\
\text { zanzibarensis }\end{array}$ & Zanzibar tonguesole & 23 & 3.60 & 0.1579 & 0.0009 \\
\hline $\begin{array}{l}\text { Southern } \\
\text { Benguela }\end{array}$ & $\begin{array}{l}\text { Emmelichthys } \\
\text { nitidus }\end{array}$ & Cape bonnetmouth & 23 & 3.61 & -0.1579 & 0.0016 \\
\hline $\begin{array}{l}\text { Southern } \\
\text { Benguela }\end{array}$ & Engraulis capensis & Cape anchovy & 27 & 2.96 & 0.2707 & 0.3658 \\
\hline $\begin{array}{l}\text { Southern } \\
\text { Benguela }\end{array}$ & $\begin{array}{l}\text { Etrumeus } \\
\text { whiteheadi }\end{array}$ & $\begin{array}{l}\text { Whiteheads round } \\
\text { herring }\end{array}$ & 27 & 3.40 & 0.6752 & 0.1517 \\
\hline $\begin{array}{l}\text { Southern } \\
\text { Benguela }\end{array}$ & $\begin{array}{l}\text { Galeichthys } \\
\text { feliceps }\end{array}$ & White baggar & 23 & 3.47 & -0.0058 & 0.0009 \\
\hline $\begin{array}{l}\text { Southern } \\
\text { Benguela }\end{array}$ & Galeorhinus galeus & Tope shark & 23 & 4.21 & -0.3450 & 0.0013 \\
\hline $\begin{array}{l}\text { Southern } \\
\text { Benguela }\end{array}$ & $\begin{array}{l}\text { Genypterus } \\
\text { capensis }\end{array}$ & Kingklip & 23 & 4.41 & 0.0058 & 0.0031 \\
\hline $\begin{array}{l}\text { Southern } \\
\text { Benguela }\end{array}$ & $\begin{array}{l}\text { Halaelurus } \\
\text { natalensis }\end{array}$ & Tiger catshark & 23 & 4.20 & -0.1228 & 0.0001 \\
\hline $\begin{array}{l}\text { Southern } \\
\text { Benguela }\end{array}$ & $\begin{array}{l}\text { Haploblepharus } \\
\text { edwardsii }\end{array}$ & Puffadder shyshark & 23 & 3.80 & 0.0877 & 0.0001 \\
\hline $\begin{array}{l}\text { Southern } \\
\text { Benguela }\end{array}$ & $\begin{array}{l}\text { Helicolenus } \\
\text { dactylopterus }\end{array}$ & Blackbelly rosefish & 23 & 3.81 & 0.0526 & 0.0051 \\
\hline $\begin{array}{l}\text { Southern } \\
\text { Benguela }\end{array}$ & $\begin{array}{l}\text { Hoplostethus } \\
\text { mediterraneus }\end{array}$ & $\begin{array}{l}\text { Mediterranean } \\
\text { slimehead }\end{array}$ & 23 & 3.49 & 0.0409 & 0.0000 \\
\hline $\begin{array}{l}\text { Southern } \\
\text { Benguela }\end{array}$ & Jasus lalandii & Cape rock lobster & 23 & 2.60 & 0.0409 & 0.0011 \\
\hline $\begin{array}{l}\text { Southern } \\
\text { Benguela }\end{array}$ & $\begin{array}{l}\text { Lampanyctodes } \\
\text { hectoris }\end{array}$ & Hectors lanternfish & 23 & 3.17 & 0.0175 & 0.0001 \\
\hline $\begin{array}{l}\text { Southern } \\
\text { Benguela }\end{array}$ & $\begin{array}{l}\text { Lepidopus } \\
\text { caudatus }\end{array}$ & Silver scabbardfish & 23 & 3.85 & 0.2632 & 0.0025 \\
\hline $\begin{array}{l}\text { Southern } \\
\text { Benguela }\end{array}$ & Loligo vulgaris & European squid & 23 & 4.10 & 0.2982 & 0.0034 \\
\hline $\begin{array}{l}\text { Southern } \\
\text { Benguela }\end{array}$ & Lophius vomerinus & Cape monk & 23 & 4.46 & 0.4152 & 0.0052 \\
\hline $\begin{array}{l}\text { Southern } \\
\text { Benguela }\end{array}$ & $\begin{array}{l}\text { Merluccius } \\
\text { capensis }\end{array}$ & South Pacific hake & 23 & 4.26 & 0.0292 & 0.0555 \\
\hline $\begin{array}{l}\text { Southern } \\
\text { Benguela }\end{array}$ & $\begin{array}{l}\text { Merluccius } \\
\text { paradoxus }\end{array}$ & $\begin{array}{l}\text { Deep-water Cape } \\
\text { hake }\end{array}$ & 23 & 4.66 & 0.2047 & 0.0809 \\
\hline $\begin{array}{l}\text { Southern } \\
\text { Benguela }\end{array}$ & Mustelus mustelus & Smooth-hound & 23 & 3.83 & 0.0877 & 0.0006 \\
\hline $\begin{array}{l}\text { Southern } \\
\text { Benguela }\end{array}$ & Mustelus palumbes & $\begin{array}{l}\text { Whitespotted } \\
\text { smooth-hound }\end{array}$ & 23 & 3.50 & 0.0526 & 0.0015 \\
\hline $\begin{array}{l}\text { Southern } \\
\text { Benguela }\end{array}$ & $\begin{array}{l}\text { Octopus } \\
\text { magnificus }\end{array}$ & $\begin{array}{l}\text { Southern giant } \\
\text { octopus }\end{array}$ & 23 & 3.96 & 0.0994 & 0.0002 \\
\hline $\begin{array}{l}\text { Southern } \\
\text { Benguela }\end{array}$ & Pagellus bellottii & Red pandora & 23 & 3.60 & -0.2632 & 0.0018 \\
\hline $\begin{array}{l}\text { Southern } \\
\text { Benguela }\end{array}$ & Palinurus gilchristi & $\begin{array}{l}\text { Southern spiny } \\
\text { lobster }\end{array}$ & 23 & 2.60 & 0.5789 & $*$ \\
\hline $\begin{array}{l}\text { Southern } \\
\text { Benguela }\end{array}$ & $\begin{array}{l}\text { Pomatomus } \\
\text { saltatrix }\end{array}$ & Bluefish & 23 & 4.50 & -0.2698 & 0.0001 \\
\hline $\begin{array}{l}\text { Southern } \\
\text { Benguela }\end{array}$ & $\begin{array}{l}\text { Pterogymnus } \\
\text { laniarius }\end{array}$ & Panga seabream & 23 & 3.68 & 0.1228 & 0.0134 \\
\hline
\end{tabular}




\begin{tabular}{|c|c|c|c|c|c|c|}
\hline $\begin{array}{l}\text { Southern } \\
\text { Benguela }\end{array}$ & Rostroraja alba & White skate & 23 & 4.40 & -0.1111 & 0.0024 \\
\hline $\begin{array}{l}\text { Southern } \\
\text { Benguela }\end{array}$ & Raja clavata & Thornback ray & 23 & 3.60 & -0.1228 & 0.0013 \\
\hline $\begin{array}{l}\text { Southern } \\
\text { Benguela }\end{array}$ & Rajella leopardus & Leopard skate & 23 & 3.90 & 0.0877 & 0.0001 \\
\hline $\begin{array}{l}\text { Southern } \\
\text { Benguela }\end{array}$ & Raja miraletus & Brown ray & 23 & 3.80 & -0.4152 & 0.0001 \\
\hline $\begin{array}{l}\text { Southern } \\
\text { Benguela }\end{array}$ & $\begin{array}{l}\text { Dipturus } \\
\text { pullopunctatus }\end{array}$ & Slime skate & 23 & 4.10 & 0.2865 & 0.0010 \\
\hline $\begin{array}{l}\text { Southern } \\
\text { Benguela }\end{array}$ & Raja straeleni & Spotted skate & 23 & 4.00 & -0.1228 & 0.0032 \\
\hline $\begin{array}{l}\text { Southern } \\
\text { Benguela }\end{array}$ & Leucoraja wallacei & Yellowspotted skate & 23 & 3.90 & 0.2164 & 0.0013 \\
\hline $\begin{array}{l}\text { Southern } \\
\text { Benguela }\end{array}$ & $\begin{array}{l}\text { Rhabdosargus } \\
\text { globiceps }\end{array}$ & White stumpnose & 23 & 2.87 & 0.0643 & 0.0002 \\
\hline $\begin{array}{l}\text { Southern } \\
\text { Benguela }\end{array}$ & $\begin{array}{l}\text { Rhinobatos } \\
\text { annulatus }\end{array}$ & Lesser sandshark & 23 & 3.40 & -0.4152 & 0.0003 \\
\hline $\begin{array}{l}\text { Southern } \\
\text { Benguela }\end{array}$ & Sardinops sagax & Pacific sardine & 27 & 2.43 & 0.4473 & 0.1677 \\
\hline $\begin{array}{l}\text { Southern } \\
\text { Benguela }\end{array}$ & Scomber japonicus & Chub mackerel & 23 & 3.09 & 0.2515 & 0.0024 \\
\hline $\begin{array}{l}\text { Southern } \\
\text { Benguela }\end{array}$ & $\begin{array}{l}\text { Sphoeroides } \\
\text { pachygaster }\end{array}$ & Blunthead puffer & 23 & 4.20 & 0.1696 & 0.0004 \\
\hline $\begin{array}{l}\text { Southern } \\
\text { Benguela }\end{array}$ & Sphyrna zygaena & $\begin{array}{l}\text { Smooth } \\
\text { hammerhead }\end{array}$ & 23 & 4.50 & -0.1416 & 0.0002 \\
\hline $\begin{array}{l}\text { Southern } \\
\text { Benguela }\end{array}$ & Squalus acanthias & Piked dogfish & 23 & 4.30 & -0.1696 & 0.0001 \\
\hline $\begin{array}{l}\text { Southern } \\
\text { Benguela }\end{array}$ & Squalus megalops & Shortnose spurdog & 23 & 4.30 & 0.1813 & 0.0268 \\
\hline $\begin{array}{l}\text { Southern } \\
\text { Benguela }\end{array}$ & Squalus mitsukurii & Shortspine spurdog & 23 & 4.50 & 0.3333 & 0.0011 \\
\hline $\begin{array}{l}\text { Southern } \\
\text { Benguela }\end{array}$ & Thyrsites atun & Snoek & 23 & 3.74 & 0.0877 & 0.0020 \\
\hline $\begin{array}{l}\text { Southern } \\
\text { Benguela }\end{array}$ & $\begin{array}{l}\text { Todarodes } \\
\text { angolensis }\end{array}$ & Angola flying squid & 23 & 4.00 & -0.0175 & 0.0002 \\
\hline $\begin{array}{l}\text { Southern } \\
\text { Benguela }\end{array}$ & Todaropsis eblanae & Lesser flying squid & 23 & 4.00 & 0.6608 & 0.0015 \\
\hline $\begin{array}{l}\text { Southern } \\
\text { Benguela }\end{array}$ & $\begin{array}{l}\text { Trachurus } \\
\text { trachurus }\end{array}$ & $\begin{array}{l}\text { Atlantic horse } \\
\text { mackerel }\end{array}$ & 23 & 3.64 & 0.0877 & 0.0575 \\
\hline $\begin{array}{l}\text { Southern } \\
\text { Benguela }\end{array}$ & $\begin{array}{l}\text { Umbrina } \\
\text { canariensis }\end{array}$ & Canary drum & 23 & 3.37 & -0.2463 & 0.0001 \\
\hline $\begin{array}{l}\text { Southern } \\
\text { Benguela }\end{array}$ & Zeus capensis & Cape dory & 23 & 4.50 & 0.3216 & 0.0053 \\
\hline $\begin{array}{l}\text { South } \\
\text { Catalan } \\
\text { Sea }\end{array}$ & Conger conger & European conger & 35 & 4.29 & -0.2874 & 0.0361 \\
\hline $\begin{array}{l}\text { South } \\
\text { Catalan } \\
\text { Sea }\end{array}$ & $\begin{array}{l}\text { Engraulis } \\
\text { encrasicolus }\end{array}$ & European anchovy & 32 & 3.11 & -0.4444 & 0.0005 \\
\hline $\begin{array}{l}\text { South } \\
\text { Catalan } \\
\text { Sea }\end{array}$ & Galeus melastomus & $\begin{array}{l}\text { Blackmouth } \\
\text { catshark }\end{array}$ & 35 & 3.73 & -0.4958 & 0.0197 \\
\hline $\begin{array}{l}\text { South } \\
\text { Catalan }\end{array}$ & Loligo & Common squids & 35 & 3.99 & -0.2437 & 0.0457 \\
\hline
\end{tabular}




\begin{tabular}{|c|c|c|c|c|c|c|}
\hline Sea & & & & & & \\
\hline $\begin{array}{l}\text { South } \\
\text { Catalan } \\
\text { Sea }\end{array}$ & Lophius & Monkfishes & 35 & 4.46 & 0.1731 & 0.0444 \\
\hline $\begin{array}{l}\text { South } \\
\text { Catalan } \\
\text { Sea }\end{array}$ & $\begin{array}{l}\text { Merluccius } \\
\text { merluccius }\end{array}$ & European hake & 35 & 4.42 & 0.0084 & 0.1887 \\
\hline $\begin{array}{l}\text { South } \\
\text { Catalan } \\
\text { Sea } \\
\end{array}$ & $\begin{array}{l}\text { Micromesistius } \\
\text { poutassou }\end{array}$ & Blue whiting & 35 & 4.01 & -0.5227 & 0.1823 \\
\hline $\begin{array}{l}\text { South } \\
\text { Catalan } \\
\text { Sea }\end{array}$ & Mullus & Western goatfishes & 35 & 3.29 & 0.1059 & 0.0582 \\
\hline $\begin{array}{l}\text { South } \\
\text { Catalan } \\
\text { Sea } \\
\end{array}$ & Octopus sp. & Octopuses & 35 & 3.80 & 0.0286 & 0.2710 \\
\hline $\begin{array}{l}\text { South } \\
\text { Catalan } \\
\text { Sea }\end{array}$ & Pleuronectiformes & Flatfishes & 35 & 3.57 & 0.6370 & 0.0405 \\
\hline $\begin{array}{l}\text { South } \\
\text { Catalan } \\
\text { Sea } \\
\end{array}$ & Sardina pilchardus & European pilchard & 32 & 3.10 & -0.1589 & 0.0016 \\
\hline $\begin{array}{l}\text { South } \\
\text { Catalan } \\
\text { Sea }\end{array}$ & Scomber & Mackerels & 35 & 3.65 & -0.2739 & 0.0092 \\
\hline $\begin{array}{l}\text { South } \\
\text { Catalan } \\
\text { Sea }\end{array}$ & Thunnus thynnus & $\begin{array}{l}\text { Atlantic bluefin } \\
\text { tuna }\end{array}$ & 26 & 4.43 & 0.0376 & $*$ \\
\hline $\begin{array}{l}\text { South } \\
\text { Catalan } \\
\text { Sea }\end{array}$ & Trachurus & $\begin{array}{l}\text { Jack and horse } \\
\text { mackerels }\end{array}$ & 35 & 3.70 & 0.2269 & 0.0765 \\
\hline $\begin{array}{l}\text { South } \\
\text { Catalan } \\
\text { Sea }\end{array}$ & $\begin{array}{l}\text { Trisopterus } \\
\text { minutus }\end{array}$ & Poor cod & 35 & 3.60 & 0.1597 & 0.0255 \\
\hline $\begin{array}{l}\text { South } \\
\text { Catalan } \\
\text { Sea }\end{array}$ & Xiphias gladius & Swordfish & 26 & 4.49 & 0.0376 & * \\
\hline $\begin{array}{l}\text { Scottish } \\
\text { west coast }\end{array}$ & Clupea harengus & Atlantic herring & 24 & 3.23 & -0.8022 & 0.1877 \\
\hline $\begin{array}{l}\text { Scottish } \\
\text { west coast }\end{array}$ & Pleuronectiformes & Flatfishes & 23 & 3.57 & 0.4387 & 0.0877 \\
\hline $\begin{array}{l}\text { Scottish } \\
\text { west coast }\end{array}$ & Gadus morhua & Atlantic cod & 24 & 4.42 & -0.8043 & 0.0080 \\
\hline $\begin{array}{l}\text { Scottish } \\
\text { west coast }\end{array}$ & Lophius & Monkfishes & 24 & 4.46 & 0.1449 & 0.0099 \\
\hline $\begin{array}{l}\text { Scottish } \\
\text { west coast }\end{array}$ & $\begin{array}{l}\text { Melanogrammus } \\
\text { aeglefinus }\end{array}$ & Haddock & 24 & 4.09 & -0.1667 & 0.0259 \\
\hline $\begin{array}{l}\text { Scottish } \\
\text { west coast }\end{array}$ & $\begin{array}{l}\text { Merlangius } \\
\text { merlangus }\end{array}$ & Whiting & 23 & 4.29 & -0.1542 & 0.0149 \\
\hline $\begin{array}{l}\text { Scottish } \\
\text { west coast }\end{array}$ & $\begin{array}{l}\text { Micromesistius } \\
\text { poutassou }\end{array}$ & Blue whiting & 24 & 4.01 & 0.6522 & 0.1812 \\
\hline $\begin{array}{l}\text { Scottish } \\
\text { west coast }\end{array}$ & $\begin{array}{l}\text { Pollachius } \\
\text { pollachius }\end{array}$ & Pollock & 24 & 4.15 & 0.0870 & 0.0116 \\
\hline $\begin{array}{l}\text { Scottish } \\
\text { west coast }\end{array}$ & Scomber scombrus & Atlantic mackerel & 24 & 3.18 & -0.4565 & 0.1729 \\
\hline
\end{tabular}




\begin{tabular}{|c|c|c|c|c|c|c|}
\hline $\begin{array}{l}\text { Scottish } \\
\text { west coast }\end{array}$ & $\begin{array}{l}\text { Trachurus } \\
\text { trachurus }\end{array}$ & $\begin{array}{l}\text { Atlantic horse } \\
\text { mackerel }\end{array}$ & 24 & 3.64 & -0.4928 & 0.1849 \\
\hline $\begin{array}{l}\text { Scottish } \\
\text { west coast }\end{array}$ & $\begin{array}{l}\text { Trisopterus } \\
\text { esmarkii }\end{array}$ & Norway pout & 23 & 3.22 & 0.2727 & 0.1154 \\
\hline $\begin{array}{l}\text { U.S. west } \\
\text { coast }\end{array}$ & $\begin{array}{l}\text { Atheresthes } \\
\text { stomias }\end{array}$ & $\begin{array}{l}\text { Arrowtooth } \\
\text { flounder }\end{array}$ & 8 & 4.26 & 0.3571 & 0.0319 \\
\hline $\begin{array}{l}\text { U.S. west } \\
\text { coast }\end{array}$ & Sebastes aurora & Aurora rockfish & 8 & 3.60 & -0.0714 & 0.0034 \\
\hline $\begin{array}{l}\text { U.S. west } \\
\text { coast }\end{array}$ & Raja binoculata & Big skate & 8 & 3.90 & -0.0714 & 0.0072 \\
\hline $\begin{array}{l}\text { U.S. west } \\
\text { coast }\end{array}$ & $\begin{array}{l}\text { Apristurus } \\
\text { brunneus }\end{array}$ & Brown catshark & 8 & 3.60 & -0.5714 & 0.0077 \\
\hline $\begin{array}{l}\text { U.S. west } \\
\text { coast }\end{array}$ & Sebastes pinniger & Canary rockfish & 8 & 3.80 & 0.0000 & 0.0145 \\
\hline $\begin{array}{l}\text { U.S. west } \\
\text { coast }\end{array}$ & Sabastes goodei & Chilipepper & 8 & 2.00 & -0.7857 & 0.0469 \\
\hline $\begin{array}{l}\text { U.S. west } \\
\text { coast }\end{array}$ & Sebastes crameri & $\begin{array}{l}\text { Darkblotched } \\
\text { rockfish }\end{array}$ & 8 & 3.70 & -0.4286 & 0.0085 \\
\hline $\begin{array}{l}\text { U.S. west } \\
\text { coast }\end{array}$ & $\begin{array}{l}\text { Embassichthys } \\
\text { bathybius }\end{array}$ & Deep-sea sole & 8 & 3.30 & 0.6429 & 0.0065 \\
\hline $\begin{array}{l}\text { U.S. west } \\
\text { coast }\end{array}$ & $\begin{array}{l}\text { Microstomus } \\
\text { pacificus }\end{array}$ & Dover sole & 8 & 3.27 & 0.0000 & 0.1959 \\
\hline $\begin{array}{l}\text { U.S. west } \\
\text { coast }\end{array}$ & Parophrys vetulus & English sole & 8 & 3.45 & -0.6429 & 0.0189 \\
\hline $\begin{array}{l}\text { U.S. west } \\
\text { coast }\end{array}$ & $\begin{array}{l}\text { Parmaturus } \\
\text { xaniurus }\end{array}$ & Filetail catshark & 8 & 3.80 & 0.1429 & 0.0042 \\
\hline $\begin{array}{l}\text { U.S. west } \\
\text { coast }\end{array}$ & Sebastes elongatus & $\begin{array}{l}\text { Greenstriped } \\
\text { rockfish }\end{array}$ & 8 & 3.60 & 0.3571 & 0.0106 \\
\hline $\begin{array}{l}\text { U.S. west } \\
\text { coast }\end{array}$ & $\begin{array}{l}\text { Sebastes } \\
\text { semicinctus }\end{array}$ & Halfbanded rockfish & 8 & 3.50 & -0.0714 & 0.0082 \\
\hline $\begin{array}{l}\text { U.S. west } \\
\text { coast }\end{array}$ & $\begin{array}{l}\text { Ophiodon } \\
\text { elongatus }\end{array}$ & Lingcod & 8 & 4.32 & -0.7143 & 0.0192 \\
\hline $\begin{array}{l}\text { U.S. west } \\
\text { coast }\end{array}$ & $\begin{array}{l}\text { Dipturus } \\
\text { oxyrinchus }\end{array}$ & Longnose skate & 8 & 3.08 & 0.4286 & 0.0412 \\
\hline $\begin{array}{l}\text { U.S. west } \\
\text { coast }\end{array}$ & $\begin{array}{l}\text { Sebastolobus } \\
\text { altivelis }\end{array}$ & $\begin{array}{l}\text { Longspine } \\
\text { thornyhead }\end{array}$ & 8 & 3.40 & 0.7143 & 0.1128 \\
\hline $\begin{array}{l}\text { U.S. west } \\
\text { coast }\end{array}$ & $\begin{array}{l}\text { Coryphaenoides } \\
\text { acrolepis }\end{array}$ & Pacific grenadier & 8 & 3.80 & -0.2143 & 0.0295 \\
\hline $\begin{array}{l}\text { U.S. west } \\
\text { coast }\end{array}$ & $\begin{array}{l}\text { Merluccius } \\
\text { productus }\end{array}$ & Pacific hake & 8 & 3.56 & -0.8571 & 0.0912 \\
\hline $\begin{array}{l}\text { U.S. west } \\
\text { coast }\end{array}$ & Sebastes alutus & Pacific ocean perch & 8 & 3.50 & 0.0000 & 0.0090 \\
\hline $\begin{array}{l}\text { U.S. west } \\
\text { coast }\end{array}$ & $\begin{array}{l}\text { Citharichthys } \\
\text { sordidus }\end{array}$ & Pacific sanddab & 8 & 3.45 & 0.0714 & 0.0486 \\
\hline $\begin{array}{l}\text { U.S. west } \\
\text { coast }\end{array}$ & Eopsetta jordani & Petrale sole & 8 & 4.05 & -0.0714 & 0.0144 \\
\hline $\begin{array}{l}\text { U.S. west } \\
\text { coast }\end{array}$ & $\begin{array}{l}\text { Glyptocephalus } \\
\text { zachirus }\end{array}$ & Rex sole & 8 & 3.24 & -0.7143 & 0.0347 \\
\hline $\begin{array}{l}\text { U.S. west } \\
\text { coast }\end{array}$ & $\begin{array}{l}\text { Anoplopoma } \\
\text { fimbria }\end{array}$ & Sablefish & 8 & 3.83 & -0.7857 & 0.0729 \\
\hline $\begin{array}{l}\text { U.S. west } \\
\text { coast }\end{array}$ & Sebastes zacentrus & Sharpchin rockfish & 8 & 3.60 & -0.7857 & 0.0169 \\
\hline $\begin{array}{l}\text { U.S. west } \\
\text { coast }\end{array}$ & $\begin{array}{l}\text { Sebastolobus } \\
\text { alascanus }\end{array}$ & $\begin{array}{l}\text { Shortspine } \\
\text { thornyhead }\end{array}$ & 8 & 3.61 & -0.2857 & 0.0372 \\
\hline U.S. west & Squalus acanthias & Spiny dogfish & 8 & 4.30 & -0.8095 & 0.0413 \\
\hline
\end{tabular}




\begin{tabular}{|c|c|c|c|c|c|c|}
\hline coast & & & & & & \\
\hline $\begin{array}{l}\text { U.S. west } \\
\text { coast }\end{array}$ & Sebastes diploproa & Splitnose rockfish & 8 & 3.70 & 0.2143 & 0.0355 \\
\hline $\begin{array}{l}\text { U.S. west } \\
\text { coast }\end{array}$ & Sebastes saxicola & Stripetail rockfish & 8 & 3.60 & -0.4286 & 0.0146 \\
\hline $\begin{array}{l}\text { U.S. west } \\
\text { coast }\end{array}$ & Sebastes flavidus & Yellowtail rockfish & 8 & 4.11 & 0.0000 & 0.0164 \\
\hline $\begin{array}{l}\text { Vancouver } \\
\text { Island }\end{array}$ & Alosa sapidissima & American shad & 31 & 3.19 & 0.0947 & 0.0005 \\
\hline $\begin{array}{l}\text { Vancouver } \\
\text { Island }\end{array}$ & $\begin{array}{l}\text { Anoplopoma } \\
\text { fimbria }\end{array}$ & Sablefish & 31 & 3.83 & 0.2602 & 0.0147 \\
\hline $\begin{array}{l}\text { Vancouver } \\
\text { Island }\end{array}$ & $\begin{array}{l}\text { Atheresthes } \\
\text { stomias }\end{array}$ & $\begin{array}{l}\text { Arrowtooth } \\
\text { flounder }\end{array}$ & 31 & 4.26 & 0.3763 & 0.0913 \\
\hline $\begin{array}{l}\text { Vancouver } \\
\text { Island }\end{array}$ & $\begin{array}{l}\text { Citharichthys } \\
\text { sordidus }\end{array}$ & Pacific sanddab & 31 & 3.45 & 0.2301 & 0.0165 \\
\hline $\begin{array}{l}\text { Vancouver } \\
\text { Island }\end{array}$ & Clupea pallasii & Pacific herring & 31 & 3.15 & 0.1957 & 0.0608 \\
\hline $\begin{array}{l}\text { Vancouver } \\
\text { Island }\end{array}$ & Eopsetta jordani & Petrale sole & 31 & 4.05 & 0.4151 & 0.0044 \\
\hline $\begin{array}{l}\text { Vancouver } \\
\text { Island }\end{array}$ & $\begin{array}{l}\text { Gadus } \\
\text { macrocephalus }\end{array}$ & Pacific cod & 31 & 4.01 & 0.2129 & 0.0192 \\
\hline $\begin{array}{l}\text { Vancouver } \\
\text { Island }\end{array}$ & $\begin{array}{l}\text { Glyptocephalus } \\
\text { zachirus }\end{array}$ & Rex sole & 31 & 3.24 & 0.4495 & 0.0459 \\
\hline $\begin{array}{l}\text { Vancouver } \\
\text { Island }\end{array}$ & $\begin{array}{l}\text { Hippoglossoides } \\
\text { elassodon }\end{array}$ & Flathead sole & 31 & 3.64 & 0.0495 & 0.0127 \\
\hline $\begin{array}{l}\text { Vancouver } \\
\text { Island }\end{array}$ & $\begin{array}{l}\text { Hippoglossus } \\
\text { stenolepis }\end{array}$ & Pacific halibut & 31 & 4.13 & 0.4366 & 0.0094 \\
\hline $\begin{array}{l}\text { Vancouver } \\
\text { Island }\end{array}$ & $\begin{array}{l}\text { Lepidopsetta } \\
\text { bilineata }\end{array}$ & Rock sole & 31 & 3.21 & -0.0989 & 0.0001 \\
\hline $\begin{array}{l}\text { Vancouver } \\
\text { Island }\end{array}$ & Lyopsetta exilis & Slender sole & 31 & 3.40 & 0.6172 & 0.0381 \\
\hline $\begin{array}{l}\text { Vancouver } \\
\text { Island }\end{array}$ & $\begin{array}{l}\text { Merluccius } \\
\text { productus }\end{array}$ & North Pacific hake & 31 & 4.35 & 0.3978 & 0.0361 \\
\hline $\begin{array}{l}\text { Vancouver } \\
\text { Island }\end{array}$ & $\begin{array}{l}\text { Microstomus } \\
\text { pacificus }\end{array}$ & Dover sole & 31 & 3.27 & 0.5183 & 0.0273 \\
\hline $\begin{array}{l}\text { Vancouver } \\
\text { Island }\end{array}$ & $\begin{array}{l}\text { Ophiodon } \\
\text { elongatus }\end{array}$ & Lingcod & 31 & 4.32 & -0.1054 & 0.0329 \\
\hline $\begin{array}{l}\text { Vancouver } \\
\text { Island }\end{array}$ & Pandalus & Pandalus shrimps & 31 & 2.60 & 0.0796 & 0.1646 \\
\hline $\begin{array}{l}\text { Vancouver } \\
\text { Island }\end{array}$ & Parophrys vetulus & English sole & 31 & 3.45 & 0.3462 & 0.0087 \\
\hline $\begin{array}{l}\text { Vancouver } \\
\text { Island }\end{array}$ & Rajidae & Skates & 31 & 3.82 & 0.4194 & 0.0133 \\
\hline $\begin{array}{l}\text { Vancouver } \\
\text { Island }\end{array}$ & Sebastes flavidus & Yellowtail rockfish & 31 & 4.11 & 0.5312 & 0.0552 \\
\hline $\begin{array}{l}\text { Vancouver } \\
\text { Island }\end{array}$ & Sebastes pinniger & Canary rockfish & 31 & 3.80 & -0.1828 & 0.0319 \\
\hline $\begin{array}{l}\text { Vancouver } \\
\text { Island }\end{array}$ & Squalus acanthias & $\begin{array}{l}\text { Pacific spiny } \\
\text { dogfish }\end{array}$ & 31 & 4.30 & -0.0624 & 0.3092 \\
\hline $\begin{array}{l}\text { Vancouver } \\
\text { Island }\end{array}$ & $\begin{array}{l}\text { Theragra } \\
\text { chalcogramma }\end{array}$ & Walleye pollock & 31 & 3.45 & -0.3591 & 0.0072 \\
\hline $\begin{array}{l}\text { Western } \\
\text { Scotian } \\
\text { Shelf }\end{array}$ & Anarhichas lupus & Atlantic wolffish & 41 & 3.24 & -0.5610 & 0.0019 \\
\hline Western & Argentina silus & Greater argentine & 41 & 3.31 & -0.2610 & 0.0036 \\
\hline
\end{tabular}




\begin{tabular}{|c|c|c|c|c|c|c|}
\hline $\begin{array}{l}\text { Scotian } \\
\text { Shelf }\end{array}$ & & & & & & \\
\hline $\begin{array}{l}\text { Western } \\
\text { Scotian } \\
\text { Shelf }\end{array}$ & Brosme brosme & Tusk & 41 & 4.00 & -0.7024 & 0.0031 \\
\hline $\begin{array}{l}\text { Western } \\
\text { Scotian } \\
\text { Shelf }\end{array}$ & $\begin{array}{l}\text { Citharichthys } \\
\text { arctifrons }\end{array}$ & $\begin{array}{l}\text { Gulf Stream } \\
\text { flounder }\end{array}$ & 41 & 3.30 & 0.3770 & $*$ \\
\hline $\begin{array}{l}\text { Western } \\
\text { Scotian } \\
\text { Shelf }\end{array}$ & Clupea harengus & Atlantic herring & 41 & 3.23 & -0.5186 & 0.6821 \\
\hline $\begin{array}{l}\text { Western } \\
\text { Scotian } \\
\text { Shelf }\end{array}$ & Gadus morhua & Atlantic cod & 41 & 4.42 & -0.5293 & 0.0166 \\
\hline $\begin{array}{l}\text { Western } \\
\text { Scotian } \\
\text { Shelf }\end{array}$ & $\begin{array}{l}\text { Hemitripterus } \\
\text { americanus }\end{array}$ & Sea raven & 41 & 4.50 & 0.0073 & 0.0015 \\
\hline $\begin{array}{l}\text { Western } \\
\text { Scotian } \\
\text { Shelf }\end{array}$ & $\begin{array}{l}\text { Hippoglossoides } \\
\text { platessoides }\end{array}$ & American plaice & 41 & 3.65 & -0.5341 & 0.0020 \\
\hline $\begin{array}{l}\text { Western } \\
\text { Scotian } \\
\text { Shelf }\end{array}$ & $\begin{array}{l}\text { Hippoglossus } \\
\text { hippoglossus }\end{array}$ & Atlantic halibut & 41 & 4.53 & 0.1585 & 0.0011 \\
\hline $\begin{array}{l}\text { Western } \\
\text { Scotian } \\
\text { Shelf }\end{array}$ & Illex illecebrosus & $\begin{array}{l}\text { Northern shortfin } \\
\text { squid }\end{array}$ & 41 & 3.98 & 0.0049 & 0.0065 \\
\hline $\begin{array}{l}\text { Western } \\
\text { Scotian } \\
\text { Shelf }\end{array}$ & Limanda ferruginea & Yellowtail flounder & 41 & 3.22 & 0.3366 & 0.0006 \\
\hline $\begin{array}{l}\text { Western } \\
\text { Scotian } \\
\text { Shelf }\end{array}$ & $\begin{array}{l}\text { Lophius } \\
\text { americanus }\end{array}$ & American angler & 41 & 4.49 & -0.5463 & 0.0020 \\
\hline $\begin{array}{l}\text { Western } \\
\text { Scotian } \\
\text { Shelf }\end{array}$ & $\begin{array}{l}\text { Melanogrammus } \\
\text { aeglefinus }\end{array}$ & Haddock & 41 & 4.09 & -0.0805 & 0.0482 \\
\hline $\begin{array}{l}\text { Western } \\
\text { Scotian } \\
\text { Shelf }\end{array}$ & $\begin{array}{l}\text { Merluccius } \\
\text { bilinearis }\end{array}$ & Silver hake & 41 & 4.26 & 0.0317 & 0.0107 \\
\hline $\begin{array}{l}\text { Western } \\
\text { Scotian } \\
\text { Shelf }\end{array}$ & $\begin{array}{l}\text { Myoxocephalus } \\
\text { octodecemspinosus }\end{array}$ & Longhorn sculpin & 41 & 3.50 & 0.3585 & 0.0014 \\
\hline $\begin{array}{l}\text { Western } \\
\text { Scotian } \\
\text { Shelf }\end{array}$ & Myxine glutinosa & Hagfish & 41 & 3.45 & 0.3114 & * \\
\hline $\begin{array}{l}\text { Western } \\
\text { Scotian } \\
\text { Shelf }\end{array}$ & Phycis chesteri & Longfin hake & 41 & 3.20 & -0.1845 & 0.0001 \\
\hline $\begin{array}{l}\text { Western } \\
\text { Scotian } \\
\text { Shelf }\end{array}$ & Pollachius virens & Saithe & 41 & 4.38 & 0.0268 & 0.0360 \\
\hline $\begin{array}{l}\text { Western } \\
\text { Scotian } \\
\text { Shelf }\end{array}$ & $\begin{array}{l}\text { Pseudopleuronectes } \\
\text { americanus }\end{array}$ & Winter flounder & 41 & 2.83 & 0.5780 & 0.0029 \\
\hline $\begin{array}{l}\text { Western } \\
\text { Scotian }\end{array}$ & Leucoraja erinacea & Little skate & 41 & 3.40 & 0.3038 & 0.0006 \\
\hline
\end{tabular}




\begin{tabular}{|c|c|c|c|c|c|c|}
\hline Shelf & & & & & & \\
\hline $\begin{array}{l}\text { Western } \\
\text { Scotian } \\
\text { Shelf }\end{array}$ & Leucoraja ocellata & Winter skate & 41 & 4.40 & -0.1073 & 0.0008 \\
\hline $\begin{array}{l}\text { Western } \\
\text { Scotian } \\
\text { Shelf }\end{array}$ & Amblyraja radiata & Starry ray & 41 & 4.00 & -0.7293 & 0.0038 \\
\hline $\begin{array}{l}\text { Western } \\
\text { Scotian } \\
\text { Shelf }\end{array}$ & $\begin{array}{l}\text { Reinhardtius } \\
\text { hippoglossoides }\end{array}$ & Greenland halibut & 41 & 4.48 & 0.4825 & * \\
\hline $\begin{array}{l}\text { Western } \\
\text { Scotian } \\
\text { Shelf }\end{array}$ & Scomber scombrus & Atlantic mackerel & 41 & 3.18 & 0.1174 & 0.0003 \\
\hline $\begin{array}{l}\text { Western } \\
\text { Scotian } \\
\text { Shelf }\end{array}$ & $\begin{array}{l}\text { Scophthalmus } \\
\text { aquosus }\end{array}$ & Windowpane & 41 & 3.55 & 0.4348 & $*$ \\
\hline $\begin{array}{l}\text { Western } \\
\text { Scotian } \\
\text { Shelf }\end{array}$ & Sebastes & Redfishes & 41 & 3.79 & 0.2317 & 0.0530 \\
\hline $\begin{array}{l}\text { Western } \\
\text { Scotian } \\
\text { Shelf }\end{array}$ & Squalus acanthias & Piked dogfish & 41 & 4.30 & 0.3732 & 0.1036 \\
\hline $\begin{array}{l}\text { Western } \\
\text { Scotian } \\
\text { Shelf }\end{array}$ & $\begin{array}{l}\text { Tautogolabrus } \\
\text { adspersus }\end{array}$ & Cunner & 41 & 3.54 & 0.0367 & $*$ \\
\hline $\begin{array}{l}\text { Western } \\
\text { Scotian } \\
\text { Shelf }\end{array}$ & Urophycis chuss & Red hake & 41 & 3.60 & 0.3877 & 0.0009 \\
\hline $\begin{array}{l}\text { Western } \\
\text { Scotian } \\
\text { Shelf }\end{array}$ & Urophycis tenuis & White hake & 41 & 4.20 & -0.2366 & 0.0165 \\
\hline
\end{tabular}

